\title{
Resumos de Dissertações de Mestrado e Teses de Doutorado apresentadas na Faculdade de Medicina de Ribeirão Preto - USP de janeiro a março de 2013
}

\author{
Biologia Celular e Molecular
}

\author{
CARACTERIZAÇÃO MOLECULAR E FUNCIONAL DOS GENES DE EXPRESSÃO RESTRITA A \\ MELANOMA, RMELS 1, 2 E 3, DESVENDADOS AQUI COMO NOVOS ALVOS \\ TRANSCRICIONAIS DAS VIAS DE MAPK E PI3K
}

\author{
Cibele Cardoso \\ Orientadora: Profa. Dra. Enilza Maria Espreafico \\ Dissertação de Mestrado apresentada em 01/03/2013
}

Melanoma é um tumor altamente agressivo devido a sua elevada capacidade metastática e resistência terapêutica. O sequenciamento em larga escala mostrou que mais de 50\% dos melanomas estão associados a uma mutação oncogênica no gene BRAF, o qual codifica a proteína serina-treonina quinase, iniciadora da cascata de MAPK. A mutação, que causa a troca do resíduo aminoácido de valina da posição 600 por um ácido glutâmico (V600E), torna a quinase independente de Ras e constitutivamente ativa. A descoberta deu lugar ao desenvolvimento de uma droga ATP-mimética (PLX4032, Vemurafenib) com alta especificidade contra a quinase mutante, capaz de excelente resposta terapêutica contra o melanoma. No entanto a remissão é temporária e o câncer recidiva em torno de 6 meses depois. Sendo assim, a identificação de novos genes envolvidos na malignidade do melanoma continua sendo essencial, com especial enfoque a se desvendar mecanismos da resistência terapêutica ao inibidor de BRAF. Sousa and Torrieri et al. (PLOS ONE, 5:1-13, 2010), em trabalho realizado em nosso laboratório, identificaram um grupo de genes com expressão restrita a melanoma, entre eles três genes não anotados, nomeados RMELs 1, 2 e 3, que mapeiam nos cromossomos 2q12.2, 1q25.3, e 5q11.2, respectivamente, e que além de restritos a melanoma, também mostraram expressão correlacionada à presença da mutação oncogênica $\mathrm{BRAF}^{\mathrm{V} 600 \mathrm{E}}$. Com base nesta evidência, os objetivos centrais do presente trabalho foram verificar a influência do oncogene BRAF na regulação da expressão gênica dos RMELs e a relevância funcional destes genes no crescimento e sobrevivência celular. Verificou-se que a inibição da cascata de MAPK com o inibidor do oncogene BRAF PLX4032, assim como a inibição de MEK1 com o inibidor PD98059, em linhagens de melanoma carregando a mutação V600E ocasionou redução significativa nos níveis de mRNAs dos genes RMELs. Com base nestes resultados, avaliamos se estes genes também seriam alvos da via de PI3K (phosphoinositideo-3-kinase), uma via alternativa de sobrevivência/proliferação celular comumente ativada em melanoma. Para esta análise utilizamos o inibidor LY294002 que age diretamente na proteína PI3K. Observamos alteração nos níveis de mRNAs dos genes em estudo, embora em graus variáveis. Adicionalmente, avaliamos os efeitos da depleção, mediada por siRNAs, dos RNAs dos RMELs na capacidade proliferativa e de sobrevivência celular. Na depleção do RMEL1, foi observado um aumento significativo na capacidade clonogênica, mas nenhum efeito na proliferação celular, entretanto para o gene RMEL3 foi demonstrada uma redução na capacidade clonogênica assim como na taxa proliferativa e nenhum efeito foi observado com a depleção do RMEL2. Os resultados obtidos demonstraram que os novos genes RMELs são potenciais alvos transcricionais das vias de MAPK e PI3K, sugerindo também o envolvimento dos genes RMEL1 e 3 no crescimento celular e/ou sobrevivência. Além disso, tivemos como objetivo construir ferramentas para forçar a expressão dos genes em linhagens celulares com baixa expressão. Com base nas sequências de mRNA mais extensas, amplificamos por RT-PCR e clonamos os cDNAs para os genes RMEL1 e RMEL3. O cDNA correspondente a sequência completa do RMEL3 foi subclonado em um vetor lentiviral sob promotor regulado por tetraciclina (doxiciclina). Células de melanoma transduzidas foram selecionadas e apresentaram um aumento de duas vezes nos níveis de expressão para este gene quando sob indução com doxiciclina. Estas células apresentam aumento da capacidade proliferativa embora não se tenha detectado em ensaios preliminares alteração na sensibilidade às drogas inibidoras de quinases da via 
de MAPK e PI3K. Finalmente, temos como objetivo verificar se a expressão dos RMELs se altera em células de melanoma selecionadas como resistentes às drogas inibidoras de quinases, após tratamento prolongado. Estas análises podem responder se estes genes estariam envolvidos na resistência terapêutica desenvolvida após tratamento prolongado. Alterações na expressão de fatores pró-apoptóticos envolvendo controle pós-transcriocional por RNAs regulatórios vem sendo recentemente descritas.

\title{
Bioquímica
}

\section{PROPRIEDADES DE SERINO PROTEASES DO VENENO DE Bothrops moojeni SENSÍVEIS A UM INIBIDOR SINTÉTICO ANÁLOGO AO SFTI-1}

\author{
Lara Aparecida Buffoni de Campos Carneiro \\ Orientador: Prof. Dr. Eduardo Brandt de Oliveira \\ Dissertação de Mestrado apresentada em 24/01/2013
}

SFTI-1, um peptídeo cíclico de 14 aminoácidos naturalmente encontrado em sementes de girassol, é um potente inibidor da atividade da tripsina. Análogos de SFTI-1 sintetizados quimicamente têm mostrado especificidade a diferentes serino proteases. Neste trabalho, serino proteases do veneno de Bothrops moojeni foram purificadas, isolando as frações cromatográficas cuja atividade sobre o substrato BApNA foi inibida por um peptídeo sintético análogo ao [Arg ${ }^{5}$ ]SFTI-I. O processo de purificação consistiu na combinação das cromatografias de troca aniônica, filtração em gel e afinidade. A proteína isolada foi caracterizada como serino protease, uma vez que sua atividade amidolítica foi inibida por PMSF. Além disso, através da técnica de fingerprinting por espectrometria de massas, foi identificado um domínio conservado da superfamília das serino proteases tipo tripsina. A proteína também foi identificada como uma serino protease agregadora de plaquetas do veneno de Bothrops jararaca. Dois fragmentos trípticos distintos da moojecitina mostraram um resíduo de aspartato possivelmente pertencente à tríade catalítica, sugerindo a presença de pelo menos dois centros catalíticos na estrutura da serino protease. Ensaios realizados em agregômetro mostraram que a serino protease isolada (0,3 U), aqui denominada moojecitina, promoveu $80,5 \%$ de agregação plaquetária no plasma rico em plaquetas. Sugere-se um possível mecanismo para a ativação plaquetária promovida pela moojecitina através da clivagem de receptores ativados por proteases (PAR) das plaquetas, pois peptídeos miméticos ao PAR1 e ao PAR4 foram clivados pela moojecitina. Além disso, embora a moojecitina não seja capaz de coagular o plasma, ela possui atividade fibrinogenolítica sobre as cadeias $\alpha A$ e $\beta B$ do fibrinogênio.

\section{ESTUDOS DA DEGRADAÇÃO DE MATERIAIS CELULÓSICOS POR ENZIMAS DE Scytalidium thermophilum E DO MUTANTE Trichoderma reesei RP698}

\author{
Jean Carlos Rodrigues da Silva \\ Orientador: Prof. Dr. João Atílio Jorge \\ Tese de Doutorado apresentada em 07/02/2013
}

Celulose é o mais abundante recurso natural biológico renovável, e sua hidrólise é catalisada por celulases endoglucanases, exoglucanases e $\beta$-glucosidades - que agem sinergicamente. Enzimas celulolíticas são empregadas em vários processos industriais, como: indústrias têxteis; extração de sucos de frutas; adição em detergentes comerciais; processamento do amido; indústrias de papel; indústrias de alimentos; e mais recentemente, na produção de bioetanol, que se apresenta como uma solução promissora para os problemas ambientais e de escassez de combustíveis fósseis. O presente trabalho teve como objetivo purificar e caracterizar celulases produzidas pelo fungo Scytalidium thermophilum, comparar o mutante Trichoderma reesei RP698 obtido em nosso laboratório com sua linhagem parental T. reesei QM9414, assim como otimizar a produção de celulases, e avaliar o potencial de aplicação de coquetéis enzimáticos com as enzimas produzidas. Foram purificadas duas celulases de $S$. thermophilum, cujas análises por espectrometria de massas demonstraram similaridade de uma com exoglucanase de Humicola grisea var. thermoidea e de outra com endoglucanase 3 de 
Humicola insolens. Ambas foram caracterizadas quanto à temperatura e pH ótimos, influência de íons (ambas fortemente ativadas por â-mercaptoetanol, cisteína e DTT), parâmetros cinéticos, determinação de massa molecular, pI, conteúdo de carboidratos e efeito da adição de glicose e celobiose na reação, em que ambas se mostraram tolerantes. Em comparação com a linhagem parental, o mutante T. reesei RP698 apresentou produção de celulases de 2 a 8 vezes superior, menor tempo de cultivo, baixa repressão catabólica, menor inibição das celulases por glicose e celobiose e maior sacarificação de substratos celulósicos e lignocelulósicos. Misturas enzimáticas entre filtrados brutos de T. reesei RP698 e S. thermophilum apresentaram alto grau de sinergismo. A otimização por planejamento fatorial (DCCR) levou a um aumento de 3 a 237 vezes a produção das enzimas testadas. O filtrado bruto otimizado de T. reesei RP698 sacarificou mais eficientemente o bagaço de cana explodido à vapor do que o coquetel comercial Accellerase ${ }^{\circledR} 1500$ e misturas enzimáticas converteram $87 \%$ do papel filtro em glicose. Os resultados encontrados sugerem que as celulases produzidas por T. reesei RP698, assim como os coquetéis enzimáticos estudados tem protencial para aplicações biotecnológicas em processos de sacarificação.

\title{
Clínica Cirúrgica
}

\author{
EFEITOS DE UM DERIVADO POLIFENÓLICO DA CAMELLIA SINENSIS NA \\ HIDROCEFALIA EXPERIMENTAL INDUZIDA EM RATOS WISTAR
}

\author{
Carlos Henrique Rocha Catalão
}

Orientadora: Profa. Dra. Luiza da Silva Lopes

Dissertação De Mestrado apresentada em 30/01/2013

A hidrocefalia é uma síndrome complexa caracterizada pelo acúmulo de líquido cérebro-espinal no interior das cavidades ventriculares. Considerando a sua fisiopatologia de caráter multifatorial sendo um dos fatores envolvidos o estresse oxidativo desencadeado pela peroxidação lipídica e formação de radicais livres, este trabalho visa estudar o possível efeito neuroprotetor proveniente do polifenol galato de epigalocatequina (EGCG) na hidrocefalia experimental. Foram utilizados ratos da linhagem Wistar $(\mathrm{N}=56)$, com 7 dias de idade. Os filhotes foram submetidos à indução da hidrocefalia pelo método da injeção intracisternal de caulim a 20\%. O polifenol foi administrado intraperitonealmente por 9 ou 20 dias consecutivos a partir da indução da hidrocefalia. Aferição do peso corporal diário e testes comportamentais foram realizados. Dez ou 21 dias após a indução da hidrocefalia os animais, profundamente anestesiados, foram sacrificados através da perfusão cardíaca com solução salina. Seus encéfalos foram removidos, fixados com paraformaldeído 3\% em tampão fosfato $0,1 \mathrm{M}$ e processados para inclusão em parafina. Preparações histológicas foram realizadas para a análise por coloração hematoxilina eosina, solocromo-cianina e imunoistoquímica para GFAP e Ki67. Os diferentes parâmetros de avaliação demonstraram que os animais tratados com o polifenol por 9 dias consecutivos apresentaram redução da atividade astrocitária através da imunomarcação pelo GFAP no corpo caloso, cápsula externa e matriz germinativa; além de apresentarem corpo caloso mais espesso e mielinizado, exibindo uma tonalidade azul mais intensa evidenciada pela coloração solocromo-cianina. Apesar desses resultados demonstrarem um possível efeito neuroprotetor na fase inicial de instalação da doença, estudos adicionais devem ser realizados para obtenção de uma terapêutica eficiente e segura para o aprofundamento com testes clínicos.

\section{PERFIL DE EXPRESSÃO DOS MICRORNAS ASSOCIADOS À APOPTOSE EM NEUROESFERAS E CÉLULAS ADERIDAS EM CULTURA DE LINHAGEM DE GLIOBLASTOMA SUBMETIDAS AO TRATAMENTO COM RADIAÇÃO IONIZANTE E TEMOZOLOMIDA}

\author{
Andressa Romualdo Rodrigues \\ Orientadora: Profa. Dra. Daniela Pretti da Cunha Tirapelli \\ Dissertação de Mestrado apresentada em 28/03/2013
}

Introdução: Glioblastomas (GBM) são os tumores cerebrais primários malignos mais comuns, e apresentam elevada taxa de mortalidade. Apesar dos atuais avanços na terapia, os GBMs são extremamente resistentes à radiação ionizante e 
quimioterápicos, e o número de recidivas é elevado. Estudos trazem que esse eminente potencial tumorigênico deve-se à presença de uma subpopulação de células neoplásicas, com características de células tronco, denominadas células tronco tumorais (CSCs). Em gliomas, o isolamento dessas células tronco tumorais tem sido feito através de marcadores antigênicos e observando as condições de cultura de células tronco neurais normais in vitro. Isto é, a proliferação de células tumorais flutuantes quando colocadas em cultura, são análogas às neurosferas derivadas das células tronco neurais normais, em condições de cultura definidas. Acredita-se que as CSCs sejam as responsáveis pelo restabelecimento do tumor e pela baixa eficácia do tratamento, visto que essas células demonstram propriedades malignas como tumorigênese, radiorresistência e quimiorresistência. A implicação prática desse achado é que nenhuma terapia atual é capaz de suprimir ou parar a proliferação dessas células. Diversos microRNAs têm sido relacionados ao desenvolvimento e proliferação dos glioblastomas, associados a diversos mecanismos moleculares, entre eles, a morte celular programada. Estudos demonstram que nos tumores cerebrais esses microRNAs apresentam níveis de expressão alterados, sendo um dos mecanismos essenciais para regulação das células tronco tumorais (CSCs).

Objetivos: Avaliar o efeito da radiação ionizante e da temozolomida, isoladas ou associadas, sobre a expressão de miRNAs que funcionam como supressores tumorais (miR-15 e miR-16) e como oncogene (miR-21), em neuroesferas e células aderidas em cultura de linhagem celular de glioblastoma (U343-MG).

Material e Métodos: O azul de trypan foi usado para verificar a viabilidade celular antes e após os tratamentos, e o método de PCR em tempo real para verificação da expressão dos microRNAs, no tempo 0h, considerado como sendo logo em seguida aos tratamentos, e 48h após a exposição aos tratamentos propostos.

Resultados e Conclusões: Os microRNAs apresentaram-se diferencialmente expressos quando comparados nas diferentes modalidades de tratamento e de tempo. Também observamos diferenças entre neuroesferas e células aderidas. O oncogene miR-21 manteve-se com maior expressão, no tratamento com radiação ionizante em neuroesferas em comparação com o grupo de células aderidas.

\title{
Farmacologia
}

\section{ESTUDO DO ENVOLVIMENTO DA VIA NMDA-NO DO EIXO DORSO-VENTRAL DO HIPOCAMPO SOBRE O COMPORTAMENTO INDUZIDO PELO ESTRESSE DE NADO FORÇADO}

\author{
Cassiano Ricardo Alves Faria Diniz \\ Orientadora: Profa. Dra. Sâmia Regiane Lourenço Joca \\ Dissertação de Mestrado apresentada em 31/01/2013
}

Acredita-se que diferenças hodológicas e diferente padrão de expressão gênica ao longo do eixo dorso/ventral do hipocampo seriam responsáveis pela distinta função entre a porção dorsal (HD) e ventral do mesmo (HV). HD seria responsável por processos cognitivos, tais como memória e aprendizagem espacial, e o HV pelas respostas neuroendócrinas e emocional-motivacionais ao estresse. No entanto, não há muitos estudos acerca de diferenças entre HD e HV na modulação de comportamentos relacionados à neurobiologia da depressão. Há, contudo, dados indicando que o bloqueio de receptores glutamatérgicos do tipo NMDA ou da síntese de NO no HD induz efeito semelhante ao dos antidepressivos (i.e. do tipo antidepressivo) no teste do nado forçado (TNF). Quanto ao HV, a função da neurotransmissão glutamatérgica/ nitrérgica na neurobiologia da depressão permanece não investigado. Dessa forma, o objetivo do presente estudo foi realizar o bloqueio reversível do HD ou do HV, em diferentes momentos, em animais submetidos ao TNF. O próximo passo foi realizar a micro-injeção intra-HD ou intra-HV do antagonista NMDA AP-7 ou do inibidor da óxido nítrico sintase neuronal (nNOS), N-PLA, ou do inibidor da guanilato ciclase solúvel (sGC), ODQ. Os resultados mostram que o bloqueio do $\mathrm{HD}$ ou do $\mathrm{HV}$ com cloreto de cobalto $\left(\mathrm{CoCl}_{2}\right.$, bloqueador da neurotransmissão sináptica dependente de cálcio) não modificou o comportamento dos animais no TNF. No entanto a administração de AP-7 ou N-PLA ou ODQ no HV antes do teste, reduziu o tempo de imobilidade no TNF. Por outro lado, a injeção dessas drogas no HD foi capaz de reduzir o tempo de imobilidade quando administradas tanto depois do pré-teste quanto antes do teste. Estes resultados sugerem que as vias NMDA-NO do HD e do HV, estariam envolvidas na modulação da resposta comportamental frente ao estresse do nado forçado. Além disso, os dados indicam que a participação dessas estruturas é importante em diferentes momentos após a exposição ao estresse. 


\title{
NOVO MÉTODO DE AVALIAÇÃO DA INCAPACIDADE ARTICULAR NA ARTRITE EXPERIMENTAL: INVESTIGAÇÃO DO PAPEL DAS CÉLULAS DA GLIA
}

\author{
Andreza Urba de Quadros \\ Orientador: Prof. Dr. Thiago Mattar Cunha \\ Dissertação de Mestrado apresentada em 05/02/2013
}

Um bom modelo experimental deve contar com métodos de avaliação eficazes de seus parâmetros. Esta é uma observação importante quando se faz necessária a avaliação da nocicepção e da incapacitação articular em animais experimentais. $\mathrm{O}$ estabelecimento de novos critérios aos testes animais é fundamental para que processos inflamatórios articulares possam continuar sendo estudados, entendidos e resolvidos. Buscando contribuir neste sentido, este trabalho realizou a padronização do teste de incapacitação dinâmico (TID) para avaliação da incapacitação articular em modelos experimentais de artrite. Os resultados obtidos mostram que o TID é sensível na avaliação da incapacitação articular em modelos de artrite induzida por antígeno (AIA) ou por zimosana. Além disso é preditivo para o estudo do efeito farmacológico de drogas que interfiram na incapacitação articular como anti-inflamatórias ou analgésicas.

Desde o início da década de 90, quando participação das células da glia na dor foi descrita, diversos trabalhos surgiram mostrando seu papel em diferentes modelos animais. A participação das células da glia espinais na dor e incapacitação em modelos experimentais de artrite e artrite reumatoide têm sido relatada, mas não há descrição desta participação em função do tempo de indução do processo inflamatório articular. Por meio de ferramentas farmacológicas e moleculares, este trabalho mostra que as células da glia, tanto espinais como do gânglio da raiz dorsal estão participando na gênese e manutenção da incapacitação inflamatória articular em modelo de AIA. A participação destas células ocorre por meio da liberação de IL-1â e TNFá em nível medular e pela primeira vez é mostrado que a ativação astrocítica parece preceder a ativação microglial neste modelo.

\section{INIBIÇÃO DA SÍNTESE DE ÓXIDO NÍTRICO INDUZ EFEITO TIPO-PANICOLÍTICO EM ANIMAIS: POSSÍVEL PARTICIPAÇÃO DE BDNF E TRKB NA SUBSTÂNCIA CINZENTA PERIAQUEDUTAL DORSAL}

\author{
Deidiane Elisa Ribeiro \\ Orientadora: Profa. Sâmia Regiana Lourenço Joca \\ Dissertação de Mestrado apresentada em 05/02/2013
}

O transtorno de ansiedade generalizada (TAG) e o transtorno de pânico (TP) são usualmente tratados com administração de benzodiazepínicos ou antidepressivos. Porém, estas drogas podem induzir uma série de efeitos adversos sendo necessário o estudo de drogas alternativas para o tratamento destes transtornos mentais. Atualmente, grande parte destes estudos utilizam modelos animais. Um modelo experimental sensível ao efeito de drogas panicoliticas e/ou ansiolíticas é o labirinto em T elevado (LTE). Amplo corpo de evidências sugere que a substância cinzenta periaquedutal dorsal (SCPD) e que a neurotransmissão glutamatérgica exercem importante papel na mediação de comportamentos defensivos. A ativação de receptores NMDA pelo glutamato pode induzir a síntese de óxido nítrico, sendo capaz de induzir respostas de fuga em modelos animais. Sabe-se ainda que a inibição da síntese de NO é capaz de facilitar a via de sinalização BDNF-TrkB e que a ativação desta via, por sua vez, é capaz de induzir efeito tipo-panicolítico. Desse modo, o presente trabalho teve como objetivo determinar o efeito do tratamento com aminoguanidina (AG), inibidor preferencial da óxido nítrico sintase induzida, em animais submetidos ao modelo do LTE e investigar o envolvimento da via de sinalização BDNF-TrkB na SCPD neste efeito. Observou-se que o tratamento repetido, mas não o agudo, com AG 15 mg/Kg induziu efeito tipo-panicolitico em ratos submetidos ao LTE e foi capaz de induzir aumento na ativação de receptores TRKB na SCPD, sem alterar os níveis de BDNF nesta estrutura. Talvez não tenha sido possível detectar alterações nos níveis de BDNF pois a quantificação desta neurotrofina é realizada em homogenato de tecido da SCPD, o que permite apenas a quantificação de BDNF total, e não daquele que é liberado e está disponível para ativar a cascata de sinalização via receptores TRKB. Portanto, mesmo não sendo detectadas alterações nos níveis de BDNF, acredita-se que o efeito tipo-panicolítico observado com o tratamento com AG pode envolver a facilitação da via BDNF-TRKB na SCPD, uma vez que foi observado um aumento na ativação dos receptores TRKB nesta estrutura. 


\title{
GÊNESE DA RESPOSTA INFLAMATÓRIA NA SEPSE POLIMICROBIANA INDEPENDE DE NOD1 E NOD2
}

\author{
Fabiane Sônego
}

Orientador: Prof. Dr. Fernando de Queiroz Cunha

Tese de Doutorado apresentada em 06/02/2013

A sepse é um grave problema de saúde pública em função das altas taxas de incidência e mortalidade. É definida como resposta inflamatória sistêmica decorrente de infecção. Em mamíferos, os principais receptores envolvidos no reconhecimento de patógenos e desencadeamento da resposta imune são os receptores Toll-like (TLR) e os NOD-like (NLR). A participação dos receptores TLR na fisiopatologia da sepse tem sido descrita. No entanto, a participação dos NLR NOD1 e NOD2 na gênese dos eventos fisiopatológicos observados na sepse não foi investigada até o momento. Desta forma, nosso objetivo foi investigar a participação dos receptores NOD1 e NOD2 na evolução da sepse polimicrobiana. Para isso, avaliamos a resposta inflamatória local e sistêmica, bem como a sobrevida de animais selvagens (WT) ou deficientes para NOD1, NOD2, duplo deficientes para NOD1/NOD2 ou ainda deficientes para a proteína adaptadora destes receptores (RIP2) após a indução de sepse utilizando a metodologia de ligação e perfuração do ceco (CLP). Inicialmente, observamos que animais deficientes para NOD1, NOD2, NOD1/NOD2 ou RIP2 apresentaram produção local de quimiocinas e recrutamento de neutrófilos ao foco infeccioso semelhantes aos animais WT. Em consequência, a carga bacteriana local e sistêmica, bem como a produção sistêmica de citocinas, sequestro de neutrófilos no pulmão e taxa de sobrevida foram similares entre os animais em estudo. Estes dados sugerem que os receptores NOD1 e NOD2 são dispensáveis para a evolução da sepse polimicrobiana. Ainda, investigamos a participação do receptor NOD1 na evolução da infecção causada por Pseudomonas aeruginosa. Para isso, inoculamos P. aeruginosa por via intranasal em camundongos WT, deficientes para NOD1 e comparamos aos animais deficientes para MyD88, que sabidamente são mais suscetíveis a esta infecção. Demonstramos que, durante a infecção por este patógeno, animais deficientes para NOD1 apresentaram produção local de quimiocinas, recrutamento de neutrófilos e carga bacteriana semelhantes aos animais WT, o que indica que NOD1 não é essencial para o controle da infecção por $P$. aeruginosa. No entanto, em concordância com dados prévios da literatura, demonstramos que os animais deficientes para MyD88 não controlaram a infecção induzida por P. aeruginosa, sugerindo que a resposta imune a este patógeno involva a ativação de via de sinalização dependente de MyD88. Assim, podemos sugerir que, em nossas condições experimentais, a evolução da sepse induzida por CLP independa de NOD1/ NOD2, assim como a evolução da infecção causada por P.aeruginosa independa de NOD1. Desta forma, estes dados contribuem para o melhor entendimento da gênese da resposta imune inata na sepse induzida por CLP e na infecção causada por $P$. aeruginosa.

\section{MECANISMOS NOCICEPTIVOS DESENCADEADOS PELA ATIVAÇÃO ESPINAL DOS RECEPTORES NOD2 (CARD15) NA GÊNESE DA DOR CRÔNICA}

\author{
David Wilson Ferreira \\ Orientador: Prof. Dr. Thiago Mattar Cunha \\ Dissertação de Mestrado apresentada em 06/02/2013
}

Entre os PRRs (receptores de reconhecimento padrão), NOD-like receptors (NLRs), tal como NOD2, são responsáveis pela detecção intracelular de muramil dipeptídeo (MDP); padrão molecular associado a patógeno (PAMP), encontrado no peptidoglicano (PGN) de praticamente todas bactérias GRAM positiva e negativa. Após o reconhecimento e estimulação por MDP, NOD2 recruta diretamente a serina-treonina quinase RIPK2, uma proteína adaptadora importante na ativação de NFKB mediada por NOD2. A expressão de NOD2 foi descrita em macrófagos e em outras células. Além disso, trabalhos anteriores indicaram que PRRs desempenham papel crucial na ativação de células gliais da medula espinal, na indução e manutenção da dor inflamatória crônica e dor neuropática. No presente estudo, avaliamos o papel de NOD2 na modulação da sensibilidade à dor, focando sua importância na ativação de células da glia da medula espinal, bem como a sua via de sinalização (RIPK2) e liberação de citocinas pró-nociceptivas, como o fator de necrose tumoral alfa (TNF- $\alpha$ ), interleucina-6 (IL-6) e interleucina-1 beta (IL-1 $\beta$ ). Os resultados demonstram que camundongos selvagens tratados com MDP, apresentaram diminuição no limiar nociceptivo mecânico (pico entre 3 e 5 horas) comparado com o grupo controle 


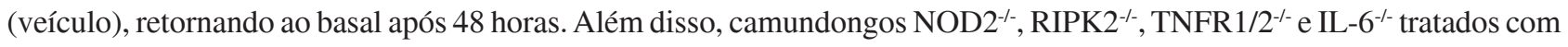
MDP não diferiram o limiar nociceptivo mecânico, comparado com seus respectivos grupos controle (veículo). Entretanto, camundongos TNFR $1^{--}$, CCR2 ${ }^{--}$, TLR4 ${ }^{--}$, MyD88 $^{--}$e TRIF $^{--}$tratados com MDP, apresentaram diminuição no limiar nociceptivo mecânico similar aos camundongos selvagens tratados com MDP. Adicionalmente, o pré-tratamento de camundongos selvagens com IL-1ra, propentofilina, minociclina, fluorocitrato e SB 203580 inibiu o desenvolvimento da hipersensibilidade mecânica induzida por MDP. Estes dados sugerem que a ativação do sensor intracellular NOD2 esta presente em células da glia da medula espinal e estimula a ativação das vias de sinalização RIPK2 e p38 MAPK com subsequente produção de IL-1 $\beta$, IL-6 e TNF $\alpha$, por uma via de sinalização independente de TLR4, MyD88 e TRIF. Finalmente, estes mecanismos contribuem para o processo de hipersensibilidade mecânica durante a neuropatia periférica e representam uma nova abordagem para elucidar os mecanismos envolvidos na fisiopatologia da dor crônica.

\title{
CONSEQUÊNCIAS DO CONSUMO CRÔNICO DE ETANOL SOBRE A REATIVIDADE E EXPRESSÃO DOS COMPONENTES DO SISTEMA ENDOTELINÉRGICO EM CORPO CAVERNOSO DE RATO
}

\author{
Letícia Nogueira Leite \\ Orientador: Prof. dr. Carlos Renato Tirapelli \\ Dissertação de Mestrado apresentada em 15/02/2013
}

A endotelina-1 (ET-1) é um peptídeo vasoconstritor que exerce um papel importante no controle do tônus do corpo cavernoso. No entanto, tem sido demonstrado que esse peptídeo também está envolvido na disfunção erétil (DE) associada ao diabetes mellitus e hipertensão. O consumo de etanol aumenta os níveis plasmáticos de ET-1 e a resposta contrátil a esse peptídeo em tecidos vasculares. Os objetivos deste trabalho foram o de estudar as consequências funcionais e celulares do consumo crônico de etanol sobre o sistema endotelinérgico no corpo cavernoso e identificar os mediadores envolvidos nessa resposta. Ratos Wistar foram divididos em dois grupos, os quais receberam água (controle) ou solução de etanol a $20 \%$ (vol./vol.) por seis semanas. Nossos resultados mostram que em tiras de tecido cavernoso, não houve alteração da resposta de relaxamento induzida pela adrenomedulina e nitroprussiato de sódio após tratamento com etanol. Com relação à acetilcolina, o consumo crônico de etanol reduziu o relaxamento induzido pelo referido agonista. Além disso, observou-se redução dos níveis plasmáticos e teciduais de nitrato no grupo etanol. Em conjunto, esses resultados sugerem que o tratamento crônico com etanol reduz a síntese/liberação do NO tecidual sem prejuízo em sua via de sinalização. O tratamento com etanol aumentou os níveis plasmáticos de ET-1 e a resposta contrátil induzida por esse peptídeo em corpo cavernoso de ratos. A contração induzida pela fenilefrina ou $\mathrm{KCl} 120 \mathrm{mmol} / \mathrm{L}$ não foi afetada pelo tratamento com etanol, sugerindo que os efeitos do tratamento sobre a reatividade do corpo cavernoso não são inespecíficos. O antagonista dos receptores $\mathrm{ET}_{\mathrm{B}}$, o BQ788, não alterou a resposta de contração induzida pela ET-1 em corpo cavernoso de animais do grupo controle ou etanol. Não houve alteração da resposta de relaxamento induzida pelo IRL1620, um agonista seletivo dos receptores $\mathrm{ET}_{\mathrm{B}}$. $\mathrm{O}$ tratamento com etanol não alterou os níveis de RNAm assim como a expressão protéica dos receptores $\mathrm{ET}_{\mathrm{B}}$. Esses resultados mostram que o aumento da contração induzida pela ET-1 após tratamento com etanol não está relacionado à redução do relaxamento mediado pelos receptores $\mathrm{ET}_{\mathrm{B}}$. Em nosso estudo o $\mathrm{BQ} 123$, antagonista seletivo dos receptores $\mathrm{ET}_{\mathrm{A}}$, deslocou a curva cumulativa para ET-1 para direita em músculo cavernoso de ratos do grupo controle com consequente redução do valor de $\mathrm{pD}_{2}$. O mesmo não foi observado no tecido de animais do grupo etanol, indicando que a resposta mediada pelos receptores $\mathrm{ET}_{\mathrm{A}}$ está favorecida após o tratamento. O consumo de etanol não afetou os níveis de RNAm dos componentes do sistema endotelinérgico (ET-1, ECE-1, receptores ET e $_{\mathrm{A}} \mathrm{ET}_{\mathrm{B}}$ ) e das isoformas da enzima óxido nítrico sintase (NOS) (eNOS, nNOS e iNOS), porém aumentou a expressão protéica do receptor $\mathrm{ET}_{\mathrm{A}}$, da ET-1 e da iNOS no músculo cavernoso. O tratamento com etanol induziu aumento do estresse oxidativo sistêmico assim como dos níveis de ânions superóxido $\left(\bullet \mathrm{O}_{2}^{-}\right)$no corpo cavernoso. As espécies reativas de oxigênio (ERO), os metabólitos derivados da NOS e da ciclooxigenase (COX) modulam negativamente a contração induzida por ET-1 e mostraram-se importantes no aumento da contração à ET-1 observada no corpo cavernoso de animais tratados com etanol. O Y27632, um inibidor da Rho-cinase, reduziu a resposta contrátil da ET-1 em corpo cavernoso de animais de ambos os grupos. Portanto, os resultados mostram que o tratamento com etanol aumenta a resposta contrátil da ET-1 por mecanismos que envolvem o aumento da expressão dos receptores ET $\mathrm{A}$ e das ERO e a via da Rho-cinase. 


\title{
RECEPTORES CANABINOIDES DO TIPO 1 MODULAM AS NEUROTRANSMISSÕES GLUTAMATÉRGICA E GABAÉRGICA NO HIPOCAMPO DORSAL DE RATOS DURANTE A RESPOSTA EMOCIONAL CONDICIONADA
}

\author{
Gabriela Bertacchini Luiz Spiacci \\ Orientador: Prof. Dr. Leonardo Resstel Barbosa de Moraes \\ Dissertação de Mestrado apresentada em 18/02/2013
}

Evidencias da literatura apontam o envolvimento do sistema endocanabinóide na modulação da expressão do medo condicionado ao contexto (MCC). Tem sido descrita a presença de expressiva quantidade de receptores canabinóide do tipo 1 (CB1) no hipocampo dorsal (HD), uma estrutura encefálica envolvida na expressão de respostas comportamentais e autonômicas observadas no MCC. A ativação de receptores CB1 do HD modula negativamente a liberação de diversos neurotransmissores, entre eles o glutamato e o GABA (ácido gama-aminobutírico). Assim o presente trabalho investigou a o possível envolvimento dos receptores CB1 do HD na modulação da resposta comportamental e autonômica desencadeadas pelo MCC. Além disso, avaliamos a possível interação com as neurotransmissões glutamatérgica e GABAérgica do HD. Na primeira etapa do trabalho analisamos o efeito da administração intra-HD do antagonista de receptores CB1, o AM251, nas doses $0,1,0,3$ e $1 \mathrm{nmol} / 500 \mathrm{~nL}$ sobre as respostas comportamentais e autonômicas expressas por ratos submetidos ao modelo do MCC. De acordo com resultados, apenas a dose $0,3 \mathrm{nmol}$ aumentou a expressão do comportamento de congelamento, elevou a pressão arterial média (PAM) e frequiência cardíaca $(\mathrm{FC})$, e promoveu a queda acentuada da temperatura cutânea caudal (TCC). Na segunda etapa, testamos uma possível interação do sistema glutamatérgico, via receptores NMDA, com a resposta promovida do AM251na dose de 0,3 nmol. Nossos resultados mostraram que a administração prévia intra-HD de uma dose inefetiva do antagonista de receptores glutamatérgicos do tipo NMDA, AP7, bloqueou o efeito do AM251, sugerindo que esta resposta é dependente da neurotransmissão glutamatérgica. Com base nas evidencias da literatura que mostram uma relação entre receptores NMDA e óxido nítrico (NO). Na terceira etapa, investigamos uma possível envolvimento do $\mathrm{NO}$ com a resposta anteriormente citada, para isso, administrou-se intra-HD um inibidor da enzima óxido nítrico sintase neuronial (nNOS), o N-Propil, na dose $0,01 \mathrm{nmol} / 500 \mathrm{~nL}$, e observamos que a resposta foi bloqueada, evidenciando assim, a interação entre endocanabinóide/NO do HD. Por fim na ultima etapa, investigamos se a ausência de efeito do AM251 nas doses 0,1 e $1 \mathrm{nmol}$ respectivamente poderia ser via neurotransmissão GABAérgica. Assim, os animais receberam intra - HD injeção do antagonista $\mathrm{GABA}_{\mathrm{A}}$, a bicuculina, na dose 1,3 pmol/500 nL. De acordo com os resultados, a administração prévia de bicuculina seguido da administração de AM251 nas doses de 0,1 e $1 \mathrm{nmol}$ foi capaz de aumentar significativamente as respostas comportamentais e autonômicas. Com base nestes resultados, podemos concluir que o sistema endocanabinoide presente no hipocampo dorsal de ratos, modula as neurotransmissões glutamatérgica e GABAérgica na expressão da REC de animais submetidos ao modelo medo condicionado ao contexto, e que também há uma interação entre glutamato/NO.

\section{INVESTIGAÇÃO DA PARTICIPAÇÃO DO INFLAMASSOMA NA GÊNESE DA DOR INFLAMATÓRIA}

\author{
Alexandre Hashimoto Pereira Lopes \\ Orientador: Prof. Dr. Thiago Mattar Cunha \\ Dissertação de Mestrado apresentada em 20/02/2013
}

A hiperalgesia inflamatória é o processo pelo qual ocorre a sensibilização dos neurônios nociceptores aferentes primários por mediadores químicos inflamatórios, gerando assim uma diminuição do limiar nociceptivo e como consequência episódios de dor. Entre os principais mediadores envolvidos com a sensibilizacão das fibras nociceptivas periféricas está a prostaglandina E2 (PGE2), que é liberada como um produto final de uma cascata de mediadores inflamatórios. Dentro desta cascata de liberação hierárquica podemos destacar a interleucina - $1 \beta$ (IL)-1 $\beta$, uma citocina importante na gênese da dor inflamatória, devido à sua capacidade de induzir a produção da enzima cicloxigenase-2 (COX-2), e consequentemente PGE2. O mecanismo de controle da produção da IL-1 $\beta$ envolvem dois passos intracelulares: a indução da expressão de uma forma protêica inativa (a pró-IL-1 $\beta$ ) e a geração da forma biologicamente ativa (IL-1â) a partir da pró-IL-1 â. Este último passo envolve a ação de uma cisteína-protease ativada em decorrência de um processo inflamatório, conhecida como Caspase-1, a qual cliva a pró-IL-1 $\beta$ em IL-1 $\beta$. Recentemente, nosso grupo demonstrou que a caspase-1 tem um papel importante na gênese da dor inflamatória, sendo crucial para a geração de IL-1 $\beta$ e consequentemente COX2/PGE2. Porém, não são conhecidos os mecanismos de ativação da caspase-1 na hiperalgesia inflamatória. Sabe-se que a ativação da 
Caspase-1 e clivagem da pro-IL-1 $\beta$ são dependentes de uma plataforma molecular intracelular denominada inflamassoma. Os principais inflamassomas ativadores de caspase-1 são formados pelas proteínas NLRP3, IPAF (NLRC4) e por sua molécula adaptadora ASC. O objetivo desse trabalho então foi avaliar a participação do inflamassoma na gênese da dor inflamatória. Nós identificamos que as moléculas IPAF e ASC, mas não o NLRP3, participa no desenvolvimento da hiperalgesia inflamatória mecânica e térmica induzida pela carragenina. Observou-se que estas moléculas são cruciais para a ativação da Caspase-1 e, consequentemente, para a produção da IL-1 $\beta$ ativa. Estes resultados evidenciam pela primeira vez um papel importante do inflamassoma no desenvolvimento da hiperalgesia inflamatória.

\title{
PARTICIPAÇÃO DA SINALIZAÇÃO BDNF-TRKB HIPOCAMPAL NO EFEITO TIPO-ANTIDEPRESSIVO INDUZIDO PELA INIBIÇÃO DA PRODUÇÃO DE NO
}

\author{
Caroline Biojone \\ Orientador: Prof. Dr. Francisco Silveira Guimarães \\ Tese de Doutorado apresentada em 18/03/2013
}

Estudos em modelos animais mostram que o estresse aumenta a produção de oxido nítrico (NO) em diversas estruturas do sistema nervoso central. Alguns efeitos do estresse sobre o comportamento de roedores são prevenidos pela inibição sistêmica ou intra-hipocampal da produção de oxido nítrico. De especial importância para o presente estudo, drogas que inibem a atividade da enzima óxido nítrico sintase (NOS) induzem efeito tipo-antidepressivo. Contudo, o mecanismo pelo qual as drogas inibidoras da NOS induzem tais efeitos não foi completamente elucidado ate então. Tem sido proposto que o estresse prejudica sinalização do BDNF (brain derived neurotrophic factor) sobre seu receptor TrkB (tropomyosin related kinase receptor $\mathrm{B}$ ) no hipocampo e que a facilitação desta via desempenha papel crucial na mediação do efeito antidepressivo. Porem, a interação entre estas duas vias (do NO e do BDNF) permanece pouco explorada. Assim, a hipótese do presente trabalho e que o estresse induz efeito pró-depressivo através do aumento da produção de NO e diminuição da sinalização BDNF-TrkB no hipocampo, ao passo que, drogas inibidoras da produção de NO induzem efeito tipo-antidepressivo e facilitação da via BDNF-TrkB nesta estrutura. Para investigar tal hipótese, ratos Wistar foram submetidos ao modelo do desamparo aprendido, no qual se avaliou o efeito do estresse ou do tratamento sistêmico com aminoguanidina (inibidor da NOS) ou imipramina (antidepressivo tricíclico) sobre: a) o comportamento associado ao estresse (comportamento de desamparo); b) os níveis de iNOS, nNOS e NOx no hipocampo; c) os níveis de BDNF e de TrkB no hipocampo. Adicionalmente, verificou-se o efeito do bloqueio de receptores TrkB sobre o efeito tipo-antidepressivo induzido pela aminoguanidina. Observou-se que o estresse aumentou a fosforização da nNOS e a concentração de NOx bem como diminuiu a fosforização de TrkB. O tratamento sistêmico repetido (7dias) com aminoguanidina ( $30 \mathrm{mg} / \mathrm{kg}$ ) ou imipramina $(15 \mathrm{mg} / \mathrm{kg})$ reverteu tais efeitos do estresse, alem de induzir efeito tipo-antidepressivo. A administração de K252a, antagonista de receptores Trk, no hipocampo ventral bloqueou o efeito tipo-antidepressivo da aminoguanidina. Concluímos que o estresse induz efeito pró-depressivo mediado pelo aumento de NO e prejuízo na ativação de receptores TrkB no hipocampo. Concluímos ainda que a inibição da produção de NO previne os efeitos do estresse por facilitar a ativação de TrkB hipocampal.

\section{FUNÇÃO DA NEUROTRANSMISSÃO NORADRENÉRGICA DO NÚCLEO MEDIAL DA AMÍGDALA NA MODULAÇÃO DO SISTEMA CARDIOVASCULAR EM RATOS}

\author{
Eduardo Albino Trindade Fortaleza \\ Orientador: Prof. Dr. Fernando Morgan de Aguiar Corrêa \\ Tese de Doutorado apresentada em 21/03/2013
}

O núcleo medial da amígdala (NMA) está envolvido no controle de uma variedade de processos fisiológicos e comportamentais, dentre eles, a regulação do sistema cardiovascular durante situações aversivas. Além disso, existem evidências indicando a presença de receptores noradrenérgicos no NMA e que os níveis de noradrenalina (NA) no NMA aumentam quando animais são submetidos ao modelo de estresse por restrição (ER). Portanto, o presente estudo foi dividido em duas partes: 1) avaliamos os efeitos da microinjeção local de NA no NMA de ratos, bem como os receptores locais e os mecanismos periféricos envolvidos na sua mediação e 2) investigamos o papel desempenhado pela neurotransmissão noradrenérgica do NMA sobre as respostas cardiovasculares causadas pelo ER. A primeira parte dos nossos 
resultados indicou que doses crescentes de NA (3, 9, 27 ou 45nmol/100nL) microinjetadas no NMA causavam respostas pressoras e bradicardicas de maneira dose-dependente em ratos não anestesiados. Os efeitos da NA no NMA foramabolidos pelo pré-tratamento local com antagonista de receptores á2-adrenérgicos (RX821002, 10 nmol/100nL), porém não foram alterados pelo pré-tratamento com antagonista de receptores áladrenérgicos (WB4101, $10 \mathrm{nmol} / 100 \mathrm{~nL}$ ). A magnitude da resposta pressora à NA no NMA foi aumentada pelo pré-tratamento intravenoso (i.v.) com o bloqueador ganglionar pentolínio $(5 \mathrm{mg} / \mathrm{kg})$ e foi significativamente reduzida pelo pré-tratamento i.v. com antagonista dos receptores vasopressinérgicos do tipo $\mathrm{V} 1 \mathrm{dTyr}(\mathrm{CH} 2) 5(\mathrm{Me}) \mathrm{AVP}(50 \mu \mathrm{g} / \mathrm{Kg})$ sugerindo que o mecanismo periférico envolvido nestas respostas cardiovasculares é a liberação de vasopressina na circulação sanguínea. Como estruturas finais participando das respostas cardiovasculares desencadeadas pela microinjeção de NA no NMA, foi observado o possível envolvimento dos núcleos paraventricular (NPV) e supra-óptico (NSO) do hipotálamo, que sintetizam vasopressina. O bloqueio de sinapses, tanto no NPV quanto no NSO, com cloreto de cobalto (CoCl2, 1mM/100nL), reduziu as respostas cardiovasculares desencadeadas pela microinjeção de NA no NMA, sugerindo que ambos os núcleos são responsáveis pela liberação de vasopressina em resposta à NA no NMA. Na segunda parte deste estudo, os resultados mostraram que a microinjeção bilateral de WB4101, antagonista seletivo dos receptores $\alpha 1$-adrenérgicos (10, 15 e 20nmol/100nL) no NMA 10 min antes do ER, reduziu a resposta taquicárdica evocada pelo ER, de maneira dose-dependente. Em contraste, a microinjeção bilateral de RX821002, antagonista seletivo dos receptores $\alpha 2$-adrenérgicos (10, 15 e 20nmol/100nL) no NMA 10 min antes do ER, aumentou a resposta taquicárdica evocada pelo ER de maneira dose-dependente. Ambos os tratamentos não causaram alterações na resposta pressora observada nos animais submetidos ao ER. Estes resultados sugerem que receptores $\alpha 1$ - e $\alpha 2$-adrenérgicos no NMA desempenham papel facilitatório e inibitório, respectivamente, na resposta taquicárdica durante o ER. Além disso, a microinjeção bilateral de propranolol, antagonista não seletivo dos receptores $\beta$ adrenérgicos $(10,15$ e 20nmol/100nL), no MNA 10 min antes do ER, causou aumento na resposta taquicárdica apenas quando os animais foram pré-tratados com a dose de $15 \mathrm{nmol}$, sem efeito significativo sobre a resposta pressora observada durante o ER. Este resultado indica que receptores $\beta$-adrenérgicos no NMA desempenham um papel inibitório sobre a frequência cardíaca durante o ER. Uma vez que foi observada a participação dos receptores $\beta$-adrenérgicos, realizamos o pré-tratamento com os antagonistas seletivos dos receptores $\beta 1$ - e $\beta 2$ - adrenérgicos, CGP 20712 e ICI 118,551, respectivamente. A microinjeção bilateral de ICI 118,551 (10, 15 e 20nmol/100nL) no NMA aumentou as respostas taquicárdicas ao ER após a microinjeção das doses de 15 e 20 nmol. Esse efeito foi semelhante ao observado após o tratamento prévio com propranolol, na dose de $15 \mathrm{nmol}$, sem efeito significativo sobre a resposta da pressora durante o ER. Porém, o prétratamento com o CGP 20712 (10, 15 e 20 nmol/100 nL) causou um efeito oposto sobre a resposta taquicárdica evocada pelo ER, ocorrendo uma redução da resposta taquicárdica que foi observada apenas após a dose de 20 nmol no NMA, sem efeito significativo sobre a resposta pressora evocada pelo ER. Esses resultados sugerem que os receptores â2-adrenérgicos desempenham influência inibitória sobre a resposta taquicárdica, ao passo que, os receptores â1-adrenérgicos desempenham influência facilitatória na resposta taquicárdica evocada pelo ER.

\title{
ENVOLVIMENTO DA NEUROTRANSMISSÃO OPIOIDÉRGICA DO CÓRTEX PRÉ-FRONTAL MEDIAL NA MEDIAÇÃO DAS RESPOSTAS CARDIOVASCULARES CAUSADAS PELO ESTRESSE DE RESTRIÇÃO EM RATOS
}

\author{
Aline Fassini \\ Orientador; Prof. Dr. Fernando Morgan de Aguiar Corrêa \\ Dissertação de Mestrado apresentada em 25/03/2013
}

O córtex pré-frontal medial ventral (CPFMv) é uma estrutura límbica que está envolvida em respostas autonômicas associadas a reações aversivas. O CPFMv é dividido em córtex pré-límbico (PL), córtex infralímbico (IL) e córtex dorsopeduncular (DP). A estimulação elétrica ou química destas regiões causa respostas defensivas e alterações autonômicas tais como respostas cardiovasculares, dependendo da sub-região estimulada. O estresse de restrição (ER) causa alterações hormonais e respostas autonômicas, tais como aumento de pressão arterial (PA) e frequência cardíaca (FC). A ativação de neurônios presentes no CPFMv durante essa situação aversiva, assim como os resultados da inibição farmacológica das sinapses presentes no PL e IL sugerem o envolvimento destas estruturas na modulação das respostas cardiovasculares causadas pelo ER. Entretanto, os possíveis neurotransmissores presentes no vCPFM, envolvidos nesta modulação, ainda não foram elucidados. O sistema opioidérgico central modula o sistema cardiovascular inclusive durante situações aversivas, sendo que tanto receptores quanto peptídeos opióides estão presentes no CPFMv. Considerando o exposto acima, a hipótese a ser testada no presente trabalho foi que a neurotransmissão opioidérgica do PL e IL está 
envolvida na modulação das respostas cardiovasculares de aumento da PA e FC desencadeadas pelo ER. Assim, a administração de naloxona (antagonista não-seletivo de receptores opióides) no PL ou IL reduziu a resposta pressora e taquicardíaca induzida pelo ER, sendo o perfil da curva dose-inibição em forma de U-invertido. A administração de CTAP (antagonista dos receptores opióides $\mu$ ) ou nor-BNI (antagonista dos receptores opióides ê) no PL também reduziu a resposta pressora e taquicardíaca induzida pelo ER, de forma semelhante à naloxona, sugerindo o envolvimento desses receptores na modulação das respostas cardiovasculares desencadeadas pelo ER, enquanto que no IL, apenas a administração de nor-BNI reduziu a resposta cardiovascular induzida pelo ER. O tratamento com naltrindole (antagonista äseletivo) em ambas as estruturas não alterou a resposta pressora e taquicardíaca gerada pelo ER. A administração de UPF101 (antagonista ORL-1) no PL potencializou a resposta taquicardíaca, sem alterar a resposta pressora enquanto a administração no IL não gerou efeito. Em resumo, os resultados indicam que o sistema opioidérgico, presente no PL e IL, desempenha papel facilitatório sobre as respostas cardiovasculares induzidas pelo ER, enquanto o sistema nociceptina/ orfanina FQ apresentaria papel inibitório.

\section{PAPEL DA O-GLICOSILAÇÃO COM N-ACETIL-GLUCOSAMINA (O-GLCNAC) NO INFLUXO E RECAPTAÇÃO DE CÁLCIO PELO RETÍCULO SARCOPLASMÁTICO EM AORTA DE RATOS: ANÁLISE FUNCIONAL}

\section{Camila Ziliotto Zanotto}

Orientador: Profa. Dra. Rita de Cássia Aleixo Tostes Passaglia

Dissertação de Mestrado apresentada em 28/03/2013

A $O$-glicosilação com $N$-acetil-glucosamina $(O$-GlcNAc) é uma modificação pós-translacional altamente dinâmica que modula diversas vias de sinalização. O processo de $O$-GlcNAc é controlado por duas enzimas: a enzima OGT é responsável por catalisar a adição de $N$-acetil-glucosamina no grupo hidroxila dos resíduos de serina e treonina, enquanto a OGA catalisa a remoção de $O$-GlcNAc das proteínas modificadas. Proteínas com importante papel na função vascular são alvo de $O$-GlcNAc e o aumento da expressão de proteínas modificadas por $O$-GlcNAc promove aumento da reatividade vascular para estímulos contráteis. Um dos mecanismos de extrema importância no controle do tônus vascular está ligado à regulação da concentração de cálcio $\left(\mathrm{Ca}^{2+}\right)$ intracelular, onde destacamos a participação do sistema STIM1/Orai1. As moléculas de interação estromal (STIM) atuam como sensores dos estoques intracelulares de $\mathrm{Ca}^{2+} \mathrm{e}$ as proteínas Orai representam as subunidades que formam os canais de $\mathrm{Ca}^{2+}$ ativados pela liberação de $\mathrm{Ca}^{2+}$ (CRAC). Neste estudo investigamos a hipótese de que o aumento dos níveis vasculares de proteínas glicosiladas aumenta a resposta contrátil em aorta de ratos, por mecanismos relacionados ao controle da concentração intracelular de $\mathrm{Ca}^{2+}$.Em nossos experimentos, utilizamos aortas torácicas de ratos incubadas com PugNAc (inibidor seletivo da OGA, $100 \mathrm{mM}$ ), por 24h. Utilizando protocolo experimental que permite avaliar contrações induzidas pelo influxo de $\mathrm{Ca}^{2+}$ e liberação de $\mathrm{Ca}^{2+}$ intracelular, demonstramos que a incubação com PugNAc aumentou a resposta contrátil à PE bem como a contração durante o período de influxo de $\mathrm{Ca}^{2+}$, induzida pela reintrodução de solução fisiológica contendo $\mathrm{Ca}^{2+}(1,56 \mathrm{mM})$. O bloqueio dos canais CRAC com 2-APB $(100 \mathrm{mM})$ e gadolíneo $\left(\mathrm{Gd}^{3+}, 100 \mathrm{mM}\right)$ diminuiu significativamente as contrações induzidas pelo influxo de $\mathrm{Ca}^{2+}$ em aortas incubadas com PugNAc. Além disso, estas aortas apresentaram aumento da expressão protéica de STIM1, o que resultaria em maior influxo de $\mathrm{Ca}^{2+}$. A contração induzida por cafeína $(20 \mathrm{mM})$ e serotonina $(10 \mathrm{mM})$, a qual reflete a capacidade funcional do retículo sarcoplasmático (RS) em captar $\mathrm{Ca}^{2+}$, foi maior em aortas incubadas com PugNAc. O papel da $\mathrm{Ca}^{2+}$ ATPase (SERCA) foi avaliado com a utilização de tapsigargina, bloqueador da SERCA. O efeito da tapsigargina foi semelhante em artérias incubadas com PugNAc e veículo, apesar do aumento de expressão proteica da SERCA em aortas incubadas com PugNAc. Como a proteína cinase C (PKC) é ativada por aumentos de $\mathrm{Ca}^{2+}$ intracelular, determinamos se a atividade de proteínas alvo da PKC estavam aumentadas. A incubação com PugNAc aumentou a expressão das formas fosforiladas da CPI-17, MYPT-1 e MLC. Em conjunto, estes resultados sugerem que a ativação de STIM1/Orai1, aumento da liberação de $\mathrm{Ca}^{2+}$ intracelular e ativação da via de sinalização da PKC podem representar mecanismos que modulam as alterações vasculares em resposta ao aumento de proteínas glicosiladas por $O$-GlcNAc. 


\title{
Fisiologia
}

\section{INFLUÊNCIA DO PADRÃO DE ALIMENTAÇÃO SOBRE O SISTEMA CLOCK DO HIPOTÁLAMO E DO SANGUE PERIFÉRICO}

\author{
Leonardo Domingues deAraujo \\ Orientadora: Profa. Dra. Margaret de Castro \\ Dissertação de Mestrado apresentada em 24/01/2013
}

Introdução: Antecipação à disponibilidade de alimentos tem sido associada a alterações nos ritmos circadianos de expressão de genes e proteínas envolvidos na regulação do sistema biológico de temporização circadiana. Poucos autores avaliaram sistematicamente a expressão desses genes, no que se refere às modulações por fatores sincronizadores não fóticos, como o padrão temporal de oferta alimentar.

Objetivos: Avaliar a expressão dos genes envolvidos na regulação do sistema de temporização circadiano nos núcleos hipotalâmicos e em sangue periférico de animais submetidos a diferentes padrões de alimentação.

Material e métodos: Ratos Wistar foram aclimatados por cinco dias à temperatura ambiente controlada $\left(23 \pm 2^{\circ} \mathrm{C}\right)$, sob-regime de luz com ciclo claro/escuro de 12:12h (luzes acesas das 06:00 às 18:00h) e submetidos a diferentes padrões de alimentação: controle (ad libitum), restrição alimentar (oferta de alimento entre 1800 e 2000h) e restrição alimentar com inversão do padrão alimentar (oferta de alimento entre 0900 e 1100h), por 21 dias. Os animais foram decapitados em dois momentos, às 0900ZT e 1700ZT e sangue periférico coletado para dosagem de corticosterona, por radioimunoensaio. Os núcleos hipotalâmicos supraquiasmáticos (NSQ), arqueado (Arq) e paraventricular (PVN) foram microdissecados pela técnica de punch. RNA extraído por Trizol e reação de transcrição reversa foi realizada com a enzima MultiScribeTMe pelo kit High CapacityTM. A expressão dos genes Clock, Bmal1, Per1, Per2, Per3, Cryl e Cry2 foi determinada pela fórmula 2- $\Delta \Delta \mathrm{Ct}$, por qPCR.

Resultados: Os animais do grupo controle apresentaram maior peso comparados aos grupos restrição sem e com inversão do padrão alimentar (385,4 $55,4 \mathrm{~g} v s 245,5 \pm 32,0 \mathrm{~g}$ vs $227,9 \pm 40,9 \mathrm{~g} ; \mathrm{P}<0,0001)$, o mesmo foi observado com a quantidade diária de alimento ingerido $(31,2 \pm 3,9 \mathrm{~g}$ vs $14,1 \pm 1,8 \mathrm{~g} v s 13,3 \pm 1,6 \mathrm{~g} ; \mathrm{P}<0,0001)$. Os animais do grupo controle apresentaram valores de corticosterona às $0900 \mathrm{ZT}$ menores que às $1700 \mathrm{ZT}(1,0 \pm 0,6 v s 14,1 \pm 8,1 ; \mathrm{P}=0,0004)$, o mesmo foi observado com o grupo restrição sem inversão do padrão de ingestão alimentar $(3,6 \pm 2,6 \mathrm{~g} v s 20,7 \pm 7,6 \mathrm{~g} ; \mathrm{P}<0,0001)$. Entretanto, os animais do grupo com restrição e inversão do padrão alimentar apresentaram concentrações de corticosterona $(\mu \mathrm{g} / \mathrm{dL})$ maiores às 0900ZT comparadas com as 1700ZT $(22,7 \pm 6,2 v s 10,6 \pm 5,7 ; \mathrm{P}=0,0007)$. Não houve diferença na expressão dos genes Clock, Bmal1, Perl, Cryl e Cry 2 nos NSQ dos animais do grupo controle entre os diferentes horários; ao contrário, Per2 e Per3 apresentaram maior expressão às 1700ZT, coincidente com os valores mais elevados de corticosterona observados nos animais desse grupo nessa fase. Ainda, nos NSQ, a expressão de Perl no grupo restrição com inversão do padrão alimentar foi maior à tarde, sugerindo perda da expressão entre manhã e tarde observada nos animais do grupo controle. No PVN, as expressões dos genes Clock e Bmall não foram diferentes em nenhuma das condições experimentais. No entanto, os genes Perl, Per2, Per3 e Cry2 apresentaram maior expressão nos animais do grupo controle e restrição alimentar decapitados às 1700ZT. Por outro lado, os animais do grupo restrição com inversão do padrão alimentar apresentaram maior expressão do Perl nos animais decapitados às 0900ZT, ou seja, houve inversão no seu padrão de expressão. Padrão semelhante foi observado na expressão do Perl no Arq dos animais do grupo restrição com inversão do padrão alimentar. Dessa forma, no PVN e no Arq, o aumento da expressão de Perl ocorreu por volta do horário da alimentação, independente da hora do dia que o alimento está disponível.

Conclusão: Nossos dados não permitem conclusões sobre a variação circadiana dos genes envolvidos na regulação do sistema de temporização, entretanto, sugerem que padrões de restrição alimentar podem modular a expressão diária de alguns desses genes no NSQ e em osciladores extra-NSQ, como por exemplo, no PVN e Arq, núcleos esses relacionados a sinais não fóticos e envolvidos na homeostase energética e na motivação para a ingestão de alimento. Palavras chaves: Sistema de Temporização Circadiana, Expressão Gênica, Genes Clock, Bmal1, Per1, Per2, Per3, Cry1 e Cry2. 


\title{
AÇÃO DA PROTEINA-QUINASE ATIVADA POR RNA NA NEUROBIOLOGIA DA DOR CRÔNICA
}

\author{
Ricardo Kusuda \\ Orientador: Prof. Dr. Guilherme de Araujo Lucas \\ Tese de Doutorado apresentada em 21/02/2013
}

A proteína-quinase ativada por RNA de dupla-fita (PKR) foi inicialmente identificada e caracterizada como um inibidor transducional em processos antivirais regulados por intérferons (IFNs). Vários trabalhos a indicam como mediadora de múltiplos processos celulares via fosforilação de substratos protéicos contribuindo para manutenção da homeostasia, mediação de respostas imunológicas, controle do crescimento celular, apoptose e repostas ao estresse celular. Esta capacidade de resposta a múltiplos estímulos indica uma ampla função de PKR na regulação da transcrição e transdução de sinais associados a diversos processos patofisiológicos, incluindo a dor. Primeiramente, este trabalho investigou a imunoreatividade celular de PKR na coluna dorsal da medula espinal. Neurônios, e não astrócitos e células da microglia, expressam PKR extensamente ao longo de toda coluna dorsal. A forma fosforilada de PKR foi significantemente aumentada 3 dias após injeção de Adjuvante Completo de Freund (CFA), ipsilateralmente à pata inflamada. A inibição de PKR na medula espinal nitidamente reduziu a hiperalgesia térmica de origem inflamatória de maneira concentração-dependente. Estes resultados foram comprovados pela indução de inflamação periférica em animais modificados geneticamente para não expressarem PKR (PKR-/-). Hiperalgesia térmica, mas não alodinia mecânica, foi abolida em camundongos PKR-/-. Entretanto, não foi encontrada nenhuma evidência de que PKR está envolvida com modelos de dor neuropática. Além disso, sua atividade está associada apenas com condições de dor inflamatória persistente e não aguda. A inflamação crônica periférica aumentou os níveis de fosforilação de p38, JNK e IKK. A administração intratecal de TNFo, IL-1 $\beta$ e IFN- $\gamma$ induziram hiperalgesia térmica nos camundongos PKR +/+ e PKR -/-. Contudo, o efeito de TNFá se mostrou significantemente reduzido nos animais mutantes para PKR. Juntos, estes resultados indicam que PKR tem uma função pró-nociceptiva na coluna dorsal da medula espinal via sinalização por múltiplas vias intracelulares que incluem a ativação de p38, JNK e IKK. Ademais, a atividade de PKR é um importante componente da dor mediada por TNFo na medula espinal. Desta forma, surge então uma substancial evidência de que PKR é um novo mediador crítico para a transdução da dor inflamatória na coluna dorsal e que sua função pró-nociceptiva é tempo, estímulo e origem-dependentes.

\section{VIAS DE SINALIZAÇÃO ENVOLVIDAS NA AÇÃO ANTIPROTEOLÍTICA DE AGONISTAS ADRENÉRGICOS $\beta 2$ EM MÚSCULOS ESQUELÉTICOS DE ROEDORES}

\author{
Dawit Albieiro Pinheiro Gonçalves \\ Orientador: Prof. Dr. Luiz Carlos Carvalho Navegantes \\ Tese de Doutorado apresentada em 22/02/2013
}

Embora a ação antiatrófica dos agonistas adrenérgicos $\beta 2$ na musculatura esquelética seja bem conhecida, os mecanismos moleculares só começaram a ser desvendados mais recentemente. Além da sinalização adrenérgica $\beta 2$ canônica do AMPc/PKA/CREB, diversas outras vias de sinalizações, tais como as vias clássicas da insulina, têm sido relacionadas aos efeitos metabólicos desses simpaticomiméticos. Portanto, o objetivo do presente trabalho foi investigar o envolvimento das sinalizações da PKA, Akt/Foxo e MEK/ERK1/2 na ação antiproteolítica dos agonistas â2 formoterol (FOR) e clembuterol (CB) em músculos esqueléticos e células musculares $\mathrm{C} 2 \mathrm{C} 12$ de roedores . Para isso, foram utilizados métodos bioquímicos e de biologia molecular para a análise da degradação de proteínas e para a quantificação do nível de fosforilação de diferentes moléculas sinalizadoras e de expressão de genes relacionados à atrofia (atrogenes) e à autofagia. Os resultados mostram que a administração aguda (após 1 e 4h) de FOR ou CB aumentou os níveis de AMPc e suprimiu a expressão da Atrogin-1, MuRF1 e Gabarapl1 induzida por 2 dias de jejum em músculos glicolíticos de camundongos. O FOR e o CB in vitro reduziram a proteólise total induzida pelo jejum em EDL, indicando que a ação dos agonistas $\beta 2$ na musculatura é direta. Em paralelo, observou-se que ambos agonistas $\beta 2$ ativaram por fosforilação a Akt, ERK1/2 e CREB, e inativaram Foxo, o principal fator responsável pela transcrição dos atrogenes, tanto em músculo adulto (in vivo) como em cultura de células (in vitro). A ação estimulante do CB na Akt foi abolida em músculos de camundongos nocautes (KO) para os adrenoceptores $\beta 2$. Além disso, o bloqueio farmacológico da via PI3K/Akt, mas não da via MEK/ERK1/2, em EDL de ratos jejuados preveniu a supressão da proteólise total pelo FOR. Esses resultados sugerem que a ativação da Akt e consequen- 
te inativação de Foxo é um dos mecanismos pelos quais os agonistas $\beta 2$ inibem os atrogenes em músculo glicolítico de camundongos jejuados. Em experimentos com ratos submetidos à desnervação motora, verificou-se que a inibição dos sistemas proteolíticos e dos atrogenes induzida pelo CB em músculos oxidativos é independente das sinalizações da Akt e das ERK1/2, uma vez que inibidores farmacológicos específicos dessas quinases não bloquearam os efeitos do agonista $\beta 2$. Além disso, o 6-BNZ-cAMP, um ativador da PKA, imitou os efeitos do CB em músculo oxidativo desnervado de ratos, sugerindo que outras vias de sinalização, tal como a da PKA/CREB, pode mediar as ações dos agonistas $\beta 2$. Portanto, diferentes quinases participam do controle da proteólise muscular em resposta à ativação dos adrenoceptores $\beta 2$, sendo que esta sinalização varia de acordo com o tipo de fibra muscular, modelo atrófico e espécie estudada. Esses achados contribuem para a identificação de novas estratégias para a atenuação da atrofia muscular em situações patológicas.

\title{
CARACTERIZAÇÃO DOS EFEITOS HUMORAIS E CARDIOVASCULARES DECORRENTES DO CONSUMO DE ETANOL EM RATOS
}

\author{
Andréia Lopes da Silva \\ Orientador: Prof. Dr. José Antunes Rodrigues \\ Tese de Doutorado apresentada em 01/03/2013
}

O etanol representa uma das mais importantes drogas de abuso em nossa sociedade, uma vez que seu consumo é lícito. É um agente extremamente tóxico capaz de atravessar rapidamente a barreira hemato-encefálica modificando propriedades elétricas e químicas no sistema nervoso central, consequentemente alterando respostas neuroendócrinas, comportamentais e cardiovasculares. O consumo de etanol é associado com o desenvolvimento da hipertensão, entretanto, a sequência dos eventos patofisiológicos que culminam nesta patologia é pouco conhecida, pois, os estudos feitos até agora somente avaliam a hipertensão após o seu estabelecimento. Deste modo o objetivo deste trabalho foi fazer uma evolução temporal de respostas neuroendócrinas e cardiovasculares, e sua correlação, com o desenvolvimento da hipertensão após ingestão de etanol. Ratos machos Wistar foram submetidos ao tratamento com etanol em concentrações crescentes em água de torneira (primeira semana: $5 \%$, segunda semana: $10 \%$, terceira e quarta semana: $20 \% \mathrm{v} / \mathrm{v}$ ). Após este período o etanol foi substituído por água durante uma semana. O tratamento com etanol diminui o volume circulante, o peso corporal e a ingestão de fluidos. Além do mais, a osmolalidade plasmática, o sódio plasmático e a osmolalidade urinária estavam aumentados nos grupos tratados com etanol, que também apresentaram uma diminuição no volume urinário. $\mathrm{O}$ tratamento com etanol também promove um aumento progressivo na pressão arterial média (PAM), sem alterar a frequência cardíaca. Este aumento na PAM é devido ao aumento das pressões sistólica e diastólica. Inicialmente este aumento da PAM pode ser relacionado com o aumento das concentrações plasmáticas de adrenalina e noradrenalina. Após a segunda semana de tratamento com etanol, as concentrações de catecolaminas plasmáticas diminuem, e aumento nas concentrações plasmáticas de vasopressina (AVP), angiotensina I e angiotensina II (ANG II) são observados. Não há alterações na concentração plasmática de ocitocina, corticosterona, prolactina e peptídeo natriurético atrial. A resposta da pressão arterial a agentes vasoativos está aumentada em animais tratados com etanol, e a análise do barorreflexo mostrou um possível aumento da atividade simpática no fim do tratamento. A resposta da pressão arterial à fenilefrina mostrou-se aumentada desde a primeira semana de tratamento, mostrando que o sistema é muito sensível a agentes pressores. Alterações nas respostas de relaxamento são prováveis mecanismos adaptativos para diminuir o aumento progressivo da pressão arterial induzida pelo tratamento com etanol. Esta alteração no relaxamento pode ser uma resposta à deficiência do sistema nitrérgico endógeno. A alteração tardia do barorreflexo pode estar envolvida com aumentos tardios na PAM em animais tratados com etanol. Após a retirada do etanol praticamente todos os parâmetros avaliados retornam a valores basais. Em suma, estes resultados mostram que o tratamento com etanol promove uma hipertensão moderada observada logo após o início do tratamento, sendo este efeito dependente do consumo de etanol. O sistema cardiovascular regula os efeitos promovidos pelo consumo de etanol alterando mecanismos envolvidos na manutenção do tônus vascular. Juntos estes resultados sugerem que um aumento da atividade simpática pode contribuir para o aumento inicial da PAM em animais tratados com etanol, e que a manutenção desta patologia se dá pelo aumento de outros fatores circulantes, como AVP e ANG II, sendo que a secreção de ambos os hormônios é estimulada pela desidratação. 


\title{
Genética
}

\section{O PAPEL DOS RECEPTORES NUCLEARES AMFTZ-F1 E ECR NO DESENVOLVIMENTO PUPAL DE Apis mellifera}

\author{
Tathyana Rachel Palo Mello
}

Orientadora: Profa. Dra. Zilá Luz paulino Simões

Tese de Doutorado apresentada em 25/01/2013

O desenvolvimento de insetos e a metamorfose são processos controlados por mecanismos complexos desencadeados pela ação hormonal, principalmente dos ecdisteróides e do hormônio juvenil (HJ). Os hormônios atuam por meio de moléculas mediadoras, os fatores de transcrição, que são capazes de se ligarem a regiões reguladoras dos genes alvos. Dentre os fatores de transcrição, os receptores nucleares formam uma família que inclui os membros FTZ-F1 e EcR. Sugerese que FTZ-F1 seja importante na aquisição de competência para as repostas a 20-hidroxiecdisona (20E) no período da metamorfose, além de possivelmente formar um complexo com HJ e seu provável receptor Met. Além disso, FTZ-F1 também participa na regulação da expressão do gene codificador da Vitelogenina $(\mathrm{Vg})$ em Aedes aegypti, portanto, de alguma forma está relacionado à reprodução, já que Vg é essencial para o desenvolvimento do embrião. Em nossos estudos anteriores, demonstramos que a expressão de $f t z-f l$ em A. mellifera (Amftz-fl) ocorre em momentos de baixos títulos de ecdisona, da mesma forma que em $D$. melanogaster, e essa característica é comum em moléculas envolvidas na aquisição de competência para ação de hormônios (no caso, 20E). E o knockdown de Amftz-fl em pupas provocou a queda nos níveis de transcritos de vg. EcR é o receptor de 20E e atua como heterodímero juntamente com ultraspiracle (USP). Participa de muitas vias das quais FTZ-F1 também faz parte. A mais estudada é a que leva à metamorfose. No presente estudo nos propusemos a avaliar os alvos de FTZ-F1 e EcR no período pupal do desenvolvimento de A. mellifera, pois não havia muitas informações sobre a atuação desses receptores fora do contexto da metamorfose.Também determinamos o perfil de expressão de Amftz- $f 1$ no desenvolvimento pupal de zangões, que era desconhecido. Analisamos os efeitos do knockdown de vg sobre a expressão de Amftz-fl e dos principais hormônios morfogenéticos sobre a expressão de Amftz-fl e EcR. Além disso, fizemos uma predição de microRNAs reguladores da expressão desses dois receptores nucleares. Observamos que HJ ativa a expressão de Amftz-fl e o knockdown de vg leva ao efeito contrário. Acreditamos que, assim como acontece em D. melanogaster, AmFTZ-F1 pode formar um complexo com $\mathrm{HJ}$ e seu 14 receptor, e o aumento de $\mathrm{HJ}$ levaria a um feedback positivo sobre a expressão de Amftz-fl. Esse complexo ativaria a expressão de genes alvo, como vg. E, no caso de vg, ocorreria um mecanismo de feedback negativo que levaria a diminuição da transcrição de Amftz-f1. Observamos que Amftz-fl é expresso em pupas de zangões com um perfil semelhante ao apresentado em operárias e rainhas. Ocorrem picos de expressão antes da metamorfose a antes da muda pupa-adulto, sugerindo uma participação desse fator nesses processos. Observamos um pico de expressão em uma fase de pré-pupa que apresenta altos níveis de 20E, sugerindo que a regulação de Amftz-fl por este hormônio em zangões pode ser diferente da regulação em operárias e rainhas. O knockdown de Amftz-fl alterou a expressão de 76 genes. A classe funcional relacionada a metabolismo foi a mais representativa. Foram encontrados 7 genes diferencialmente expressos que codificam constituintes estruturais da cutícula, genes expressos no cérebro e o gene similar a yellowd de D. melanogaster. Por análises de bioinformática, identificamos alguns miRNAs preditos como reguladores de Amftz-fl e $E c R$ de A. mellifera e verificamos que existem vinte miRNAs que possivelmente corregulam a expressão desses genes. Além disso, observamos que as isoformas de $E c R$ não sofrem efeito da aplicação de HJ, e a alteração nos níveis de 20E inibe $E c R-B$. O knockdown de $E c R$ levou a alterações na expressão de 67 genes, destacando-se diversos membros da família citocromo $\mathrm{P} 450$ (CYP), major royal jelly proteins (mrjp) e genes cuticulares, além de ter modificado a expressão de seis miRNAs envolvidos em processos como a regulação da apoptose, desenvolvimento do sistema nervoso e da musculatura. Portanto, este estudo demonstrou que além de serem importantes para a metamorfose, AmFTZ-F1 e EcR regulam as diversas modificações que ocorrem no período pupal de A. mellifera e que permitem às abelhas vencer todos os processos que acontecem na passagem do período larval até a fase adulta.

\section{CNVs EM PACIENTES COM LÚPUS ERITEMATOSO SISTÊMICO}

\section{Fernanda Bueno Barbosa}

Orientador: Prof. Dr. Aguinaldo Luiz Simões

Dissertação de Mestrado apresentada em 26/02/2013

O genoma humano varia entre os indivíduos não somente na forma de sequência, mas também estruturalmente. Originalmente, organismos diploides possuem duas cópias de cada região autossômica, uma por cromossomo. Entretanto, 
com o avanço das técnicas moleculares de identificação do DNA, foram descritas sequências que se repetem em diferentes regiões do genoma em número maior ou menor do que as duas cópias esperadas. Essas variantes são denominadas copy number variants $(C N V s)$ e definidas como segmentos genômicos, geralmente maiores do que 1 kilobase (kb), que variam em número de cópias em comparação com o genoma de referência. As $C N V s$ podem contribuir para a variabilidade do risco entre os indivíduos na etiologia de doenças complexas. Nesse contexto, o Lúpus Eritematoso Sistêmico (LES) é uma doença autoimune com forte componente genético, caracterizada por inflamação crônica e produção de autoanticorpos. Estudos de associação genômica em larga escala (GWAS) identificaram vários loci associados ao LES que contribuem para a susceptibilidade à patogênese. Entretanto, as pesquisas atuais com $C N V s$ e LES focalizam apenas a análise individual de algumas variantes. O objetivo do presente trabalho foi conduzir o primeiro estudo de $C N V s$ em larga escala em pacientes com LES. A detecção de $C N V s$ foi feita por ensaio de Hibridação Genômica em arrays, utilizando a plataforma Affymetrix GeneChip ${ }^{\circledR}$ CytoScan ${ }^{\mathrm{TM}} H D$ em 23 amostras de pacientes com LES. Foram identificadas 406 CNVs distribuídas em todos os cromossomos, exceto no Y. A média foi de $18 C N V s$ por paciente. As deleções foram mais frequentes do que as duplicações, 311 e 95, respectivamente. O perfil de $C N V s$ revelou $269 C N V s$ envolvendo genes, $152 C N V s$ únicas e 59 regiões de $C N V s$ (CNVRs). Nove $C N V s$ identificadas não haviam sido descritas em bancos de dados de variantes estruturais. Adicionalmente, encontramos $C N V s$ em cinco genes previamente associados com LES: CFHR4, CFHR5, STAT4, $M E C P 2$ e HLADPB2. CNVs nestes genes foram reportadas em pacientes com LES pela primeira vez. O conhecimento das $C N V s$ associadas com $L E S$ e autoimunidade podem contribuir para o entendimento da etiologia da doença. Em conclusão, o presente estudo foi o primeiro delineamento em larga escala de $C N V s$ do genoma completo em pacientes com $L E S$.

\title{
PARTICIPAÇÃO DE GENES RELACIONADOS AO PROCESSO INFLAMATÓRIO NO DIABETES mellitus GESTACIONAL
}

\author{
Nathália Joanne Bispo Cezar \\ Orientador: Prof. Dr. Geraldo Aleixo da Silva Passos Junior \\ Dissertação de Mestrado apresentada em 28/02/2013
}

O diabetes mellitus gestacional (DMG) é o distúrbio metabólico mais comum da gravidez. A definição padrão do DMG consiste no metabolismo anormal da glicose diagnosticado pela primeira vez durante a gestação. Mulheres que têm história de DMG geralmente apresentam diabetes pós-parto, resistência à insulina, síndrome metabólica, hipertensão e dislipidemia. A detecção precoce deste estado metabólico anormal é importante para eventual intervenção na tentativa de impedir ou mesmo retardar o aparecimento dos outros tipos de diabetes. Alguns estudos têm apontado, em mulheres com DMG, indução de genes envolvidos com resposta imune, particularmente aqueles associados com inflamação. A identificação de genes de inflamação induzidos em gestantes com DMG tem fornecido a base para elucidar a ligação entre vias inflamatórias e DMG. Para testar esta hipótese foi realizada a comparação do perfil transcricional de células mononucleares de sangue periférico (PBMCs) de pacientes com DMG e controles. As amostras de RNA total foram hibridadas utilizando oligo microarrays Agilent $® 4 \times 44 \mathrm{~K}$ englobando o genoma funcional humano total. Os mRNAs diferencialmente expressos foram identificados aplicando-se a análise de Rank Products, e posteriormente submetidos ao agrupamento hierárquico de Pearson por meio do software Cluster. Utilizando o programa TreeView, foi realizada a construção dos dendrogramas com as representações espaciais dos mRNAs, classificados de acordo com suas funções moleculares e vias biológicas. A partir do banco de dados DAVID, foram identificados 130 processos biológicos significantes ( $<<0.05$ ) incluindo os de resposta imune e defesa, resposta inflamatória, regulação de citocinas, apoptose, desenvolvimento de vasos sanguíneos e proliferação celular. Entre as vias de maior relevância destacamos a via de interação entre receptores de citocinas e a de sinalização do receptor NOD-like, além das vias de câncer, lúpus e asma. Adicionalmente, encontramos os transcritos dos genes IGFBP2, TCF3, OLR1, TCF7L2, previamente associados a alterações metabólicas, diferencialmente expressos nas gestantes com DMG. Também observamos que genes do complexo principal de histocompatibilidade (MHC), HLA-DRB6, HLA-DQA2, HLA-DQB2, HLA-DQB1, HLA-DOA, apresentaram mRNAs induzidos nas pacientes com DMG. A partir deste estudo, constatamos que vias relacionadas ao sistema imunológico e categorias funcionais associadas à inflamação participam da patogenia do DMG. Além disso, evidenciamos que transcritos de genes que pertencem ao MHC e aqueles envolvidos em processos metabólicos, estiveram diferencialmente expressos no DMG. Estes resultados confirmam nossa hipótese inicial e contribuem para o melhor entendimento das bases genéticas desta doença. 


\title{
HISTÓRIA DEMOGRÁFICA E ESTRUTURA DE POPULAÇÕES PARA A ESPÉCIE CACTÓFILA Drosophila meridionalis
}

\author{
Dora Yovana Barrios IEAL \\ Orientador: Profa. Dra.Maura Helena Manfrin \\ Dissertação de Mestrado apresentada em 01/03/2013
}

Drosophila meridionalis é uma espécie endêmica da América do Sul, sendo amplamente distribuída na Costa Atlântica do Brasil. Com o objetivo de elaborar uma hipótese filogeográfica para esta espécie foram obtidas sequências do gene nuclear period e do gene mitocondrial COI. Foram calculados os índices de diversidade nucleotídica e realizados os testes: AMOVA, testes de neutralidade, a Mismatch Distribution, Bayesian Skyline Plot, NCPA. Foram obtidas três redes pelo gene COI, denominadas A (populações do interior), B (populações do litoral sul) e C (populações do litoral sudeste e oriental) e uma única rede obtida para o gene period, esta rede divide as populações em dois grupos sendo o primeiro congruente com a rede A e o segundo compreendendo as redes B e C, do gene COI. A AMOVA mostrou uma estruturação alta e significativa entre as populações do interior e o litoral para os dois genes $(\Phi c t=0,72$ gene COI; $\Phi$ ct=0,70 gene period), que pode ser explicada pela presença de barreiras geográficas, como a Serra do Mar. Eventos de expansão populacional e de fluxo gênico restrito com isolamento por distância foram detectados nas populações do litoral e o interior respectivamente. A expansão da área de ocorrência de D. meridionalis provavelmente teve inicio com as populações do litoral do Rio Grande de Sul, em direção ao litoral de Santa Catarina com posterior colonização a longa distância dos estados de São Paulo, Rio de Janeiro e Bahia. Migrações assincrônicas de indivíduos de populações litorâneas de São Paulo e Santa Catarina provavelmente colonizaram o interior de São Paulo, e a partir destas populações, se iniciara uma expansão populacional em direção ao sul pelo interior, colonizando o Paraná e Rio Grande do Sul. A análise bayesiana (MCCT) indicou que o tempo do ancestral comum mais recente (TMRCA) para todos os haplótipos de D. meridionalis é de 81.700 anos atrás, data que marca a separação das populações do interior e do litoral aproximadamente no final do Pleistoceno. Eventos similares têm sido sugeridos para explicar a distribuição geográfica de espécies do cluster D. buzzatii, que ocorrem em simpatria em grande parte com populações de D. meridionalis. Esta espécie, como as espécies do cluster D. buzzatii, apresentou indicativos de flutuações demográficas, podendo estar associadas à expansão e contração da distribuição da vegetação xerofítica, durante as oscilações paleoclimáticas do Pleistoceno.

\section{MOSAICISMO E EVOLUÇÃO DO PERFIL EPIGENÉTICO DURANTE A GRAVIDEZ}

\author{
Karina Bezerra Salomão \\ Orientadora: Profa. Dra. Ester Silveira Ramos \\ Dissertação de Mestrado apresentada em 06/03/2013
}

O imprinting genômico, processo regulado epigeneticamente segundo o qual os genes se expressam de acordo com sua origem parental (paterna ou materna), está envolvido no desenvolvimento placentário. Na região cromossômica 11 p15.5 encontram-se vários genes importantes para o desenvolvimento fetal e da placenta, os quais são regulados por duas principais regiões controladoras de imprinting (ICR1 e 2) onde se encontram as regiões diferencialmente metiladas H19DMR e KvDMR1, respectivamente. O imprinting genômico e a inativação aleatória do cromossomo X são processos epigenéticos presentes em mamíferos placentários. O presente trabalho teve como objetivo principal verificar a presença de mosaicismo do perfil epigenético entre tecidos extraembrionários de estágios precoces da gravidez (primeiro trimestre), e em vilosidade coriônica de placentas a termo (terceiro trimestre). Foram coletadas amostras de 10 gestações de primeiro trimestre (vilosidade coriônica, âmion, membrana de cordão umbilical e tecido embrionário) e 14 de terceiro trimestre (vilosidade coriônica), das quais 10 foram consideradas como controles e quatro utilizadas para estudo de mosaicismo restrito à vilosidade coriônica (coleta de amostras de todos os cotilédones). Após extração do DNA, foi utilizado o Método de Digestão Enzimática Sensível à Metilação Associada à PCR em Tempo Real para o estudo do padrão de metilação da KvDMR1 e da H19DMR em diferentes tecidos do primeiro trimestre gestacional e em tecido placentário do terceiro trimestre. $\mathrm{O}$ padrão de inativação do cromossomo $\mathrm{X}$ foi avaliado em todos os cotilédones de duas placentas a termo, de fetos do sexo feminino, por meio do ensaio do receptor de andrógeno humano (HUMARA assay), utilizando eletroforese capilar, e com acréscimo de um novo marcador de inativação do cromossomo X (ICX1). Na análise estatística foram utilizados o teste t não pareado, teste de Turkey e teste $t$ pareado. A média de metilação da KvDMR1 das amostras de vilosidade coriônica do primeiro trimestre gestacional foi estatisticamente diferente da média de metilação do terceiro 
trimestre. Enquanto que a metilação da H19DMR não apresentou diferença estatística entre amostras de vilosidade coriônica do primeiro e do terceiro trimestre gestacionais. Com relação ao mosaicismo, a KvDMR1 não apresentou variação com relação ao tamanho ou a posição dos cotilédones, enquanto que a H19DMR apresentou diferença estatisticamente significativa na média de metilação com relação ao tamanho dos cotilédones e ao posicionamento nos quadrantes; em consequência da hipometilação em cotilédones pertencentes a uma das placentas estudadas. Não foram observadas diferenças estatisticamente significativas na média de metilação da KvDMR1 e da H19DMR entre diferentes tecidos das amostras do primeiro trimestre gestacional. No entanto, a comparação entre tecidos pareados de um mesmo indivíduo mostrou que a metilação não é correspondente entre os tecidos. Os dados obtidos mostram que o imprinting genômico provavelmente é um processo dinâmico, que evolui ao longo da gestação, estando relacionado a formação e ao amadurecimento da placenta. No presente estudo foi possível verificar que cotilédones de uma mesma placenta apresentam diferentes padrões de inativação do cromossomo X. Diferenças que podem ser explicadas pela expansão clonal das células trofoblásticas progenitoras com o cromossomo $\mathrm{X}$ paterno ou o cromossomo $\mathrm{X}$ materno inativo. Devido à variabilidade epigenética, exames em tecidos placentários devem considerar as diferenças intra-placentárias e as diferenças entre tecidos embrionários e extraembrionários.

\title{
DIFERENÇAS ESTRUTURAIS E "docking" RECEPTOR-LIGANTE DA PROTEÍNA E7 DO VÍRUS DO PAPILOMA HUMANO (HPV) DE ALTO E BAIXO RISCOS PARA O CÂNCER CERVICAL
}

\author{
Nilson Nicolau Junior \\ Orientadora: Profa. Dra. Silvana Giuliatti \\ Tese de Doutorado apresentada em 25/03/2013
}

O câncer cervical afeta milhões de mulheres em todo o mundo a cada ano. A maioria dos casos de câncer cervical é causada pelo vírus do papiloma humano (HPV) que é sexualmente transmissível. Cerca de 40 tipos de HPV infectam o colo do útero e estes são designados como sendo de alto ou de baixo risco com base no seu potencial para provocar lesões de alto grau e câncer. A oncoproteína E7 do HPV está diretamente envolvida no aparecimento de câncer de colo do útero. Esta se associada com a proteína pRb e outros alvos celulares que promovem a imortalização celular e carcinogênese. Apesar de muito progresso nos estudos sobre os HPVs de alto risco, ainda não existe uma terapêutica adequada para o tratamento das lesões e câncer causados por este vírus. Este trabalho teve como objetivo entender as diferenças estruturais entre E7 de alto e baixo risco e sugerir, através de análises de bioinformática, possíveis sítios de ligação e inibidores para a E7. Esta é a primeira descrição da modelagem e análise de dinâmica molecular de quatro estruturas tridimensionais completas da E7 dos tipos de alto risco (HPV tipos 16 e 18), de baixo risco (HPV tipo 11) e não relacionadas ao câncer cervical (HPV tipo 1A). Os modelos foram construídos por uma abordagem híbrida usando modelagem por homologia e $a b$ initio. Os modelos foram usados em simulações de dinâmica molecular por 50 ns, sob condições normais de temperatura e pressão. A desordem intrínseca da sequência da proteína E7 foi avaliada com o uso de ferramentas in silico. Os domínios N-terminal de todas as E7 estudadas, mesmo as de alto risco, exibiram estruturas secundárias depois da modelagem. Nas análises da trajetória da dinâmica molecular, as E7s dos HPVs dos tipos 16 e 18 apresentaram maior instabilidade nos seus domínios Nterminais em relação aos do HPV dos tipos 11 e 01 . No entanto, esta variação não afetou a conformação das estruturas secundárias durante a simulação. A análise com ANCHOR indicou que as regiões CR1 e CR2 regiões dos tipos de HPV 16 e 18 contêm possíveis alvos para a descoberta da droga. Já a região CR3 do domínio C-terminal indicou estabilidade nas análises in silico e, por isso, foi usada como alvo de busca de modelos farmacofóricos e "docking" macromolecular. A proteína usada como modelo foi a E7 do HPV tipo 45 resultante de análises de ressonância magnética nuclear (RMN) e depositada no banco 7 de dados de proteína (ID: 2F8B). Foram selecionados por análises sequenciais de busca farmacofórica, "docking" e "re-docking", 19 compostos (extraídos de amplas bibliotecas de pequenos ligantes) com potencial para candidatos a inibidores da E7. Eles foram avaliados quanto a sua função de pontuação, mapas de interação receptorligante e toxicidade e os melhores foram indicados para estudos futuros. 


\title{
Ginecologia e Obstetrícia
}

\section{INFLUÊNCIA DE UM PROTOCOLO FISIOTERAPÊUTICO NA HEMODINÂMICA MATERNA E FETAL EM GESTANTES COM PRÉ-ECLÂMPSIA}

\author{
Tawana Vicente Bertagnolli \\ Orientador: Prof. Dr. Ricardo de Carvalho Cavalli \\ Dissertação de Mestrado apresentada em 03/01/2013
}

As desordens hipertensivas na gravidez afetam 5 a $8 \%$ das gestantes em todo o mundo, contribuindo de forma significativa para complicações materno-fetais. A fisioterapia atua de forma eficaz nas desordens musculoesqueléticas decorrentes do período gestacional proporcionando melhora nos quadros álgicos relatados pelas gestantes.

O objetivo foi avaliar a eficácia de um protocolo fisioterapêutico aplicado em gestantes com pré-eclâmpsia sobre os níveis de pressão arterial e hemodinâmica materno-fetal.

Participaram do estudo, gestantes com pré-eclâmpsia e hipertensão arterial com pré-eclâmpsia sobreposta, internadas para controle clínico e obstétrico do quadro. Todas as gestantes foram monitoradas através de dados clínicos e exames laboratoriais e o feto monitorado através de cardiotocografia e ultrassonografia.

O estudo contou com a participação de 27 gestantes no total, sendo elas randomizadas e alocadas no grupo fisioterapia $(\mathrm{n}=15)$ e no grupo controle $(\mathrm{n}=12)$. Os resultados relacionados aos dados clínicos, exames laboratoriais e frequência cardíaca materna não se mostraram alterados em ambos os grupos. Os valores da pressão arterial sistólico (PAS) mínima e máxima não apresentaram diferença, porém a pressão arterial diastólico (PAD) mínima reduziu 4,74 mmHg ( $\mathrm{p}=0,001)$ e a PAD máxima diminuiu $1,27 \mathrm{mmHg}(\mathrm{p}=0,039)$ no grupo que realizou fisioterapia. Os parâmetros de cardiotocografia e ultrassonografia não apresentaram alterações significantes em nenhum dos dois grupos.

O protocolo fisioterapêutico proposto no presente trabalho não prejudicou a hemodinâmica materna e fetal, mas sim possibilitou uma redução na pressão sanguínea materna nas gestantes que realizaram fisioterapia, possibilitando a conclusão de que esse protocolo é seguro ser aplicado em gestantes com pré-eclâmpsia.

\section{ASSISTED HATCHING EM EMBRIÕES HUMANOS: UMA REVISÃO SISTEMÁTICA E METANÁLISE DE ENSAIOS CLÍNICOS CONTROLADOS}

\author{
IsaAlves Rocha \\ Orientador: Prof. Dr. Wellington de Paula Martins \\ Dissertação de Mestrado apresentada em 21/01/2013
}

Assisted hatching (AH) é a manipulação da zona pelúcida com o objetivo de facilitar a implantação embrionária. Uma revisão sistemática e metanálise da literatura médica foram realizadas avaliando o efeito de AH sobre os resultados de reprodução assistida: gestação clínica, nascidos vivos/gestação viável, gestação múltipla e aborto. Análise adicional foi realizada nos seguintes subgrupos: (1) embriões frescos transferidos em mulheres sem características específicas e sem mau prognóstico; (2) embriões frescos transferidos para mulheres com falhas repetidas em ciclos prévios; (3) embriões frescos transferidos para mulheres com idade avançada e (4) embriões congelados/descongelados transferidos para mulheres sem mau prognóstico. As análises foram realizadas baseadas em risco relativo e intervalo de confiança de $95 \%$ (RR, IC 95\%), utilizando o modelo de Mantel-Haenszel de efeito aleatório. Foram incluídos 28 estudos (5507 participantes). Houve uma tendência a aumento na taxa de gestação clínica com o uso de AH, considerando todos os participantes $(\mathrm{RR}=1,11$, IC 95\% = 1,00-1,24), e um aumento significativo nos subgrupos $2(\mathrm{RR}=1,73 \mathrm{IC} 95 \%=1,37-2,17)$ e $4(\mathrm{RR}=1,36$ IC 95\% = 1,08 - 1,72, p <0,01), mas não nos subgrupos 1 e 3. Nos casos de gestação múltipla, houve um aumento significativo considerando todos os participantes (RR 1,45, IC 95\% 1,11-1,90), assim como nos subgrupos 2 ( $\mathrm{RR}=2,53$ IC $95 \%=1,23-5,21)$ e $4(\mathrm{RR}=3,40$, IC 95\% = 1,93-6,01). Não houve heterogeneidade significativa nos subgrupos analisados. AH foi relacionada a um aumento na taxa de gestação clínica e gestação múltipla em mulheres com falhas repetidas em ciclos prévios e em mulheres submetidas à transferência de embriões congelados/descongelados. No entanto, os nossos resultados não demonstraram aumento na taxa de gestação clínica com a utilização de $\mathrm{AH}$ em embriões frescos transferidos a pacientes sem características específicas e sem mau prognóstico ou a mulheres com idade avançada. Devido à pequena amostra de estudos que avaliaram aborto e nascidos vivos/gestação viável não foi possível obter conclusão adequada em relação ao efeito de $\mathrm{AH}$ nestes desfechos. 


\title{
REPERCUSSÕES DOS EXERCÍCIOS DE TREINAMENTO DOS MÚSCULOS DO ASSOALHO PÉLVICO SOBRE OS PARÂMETROS HEMODINÂMICOS ÚTERO PLACENTÁRIOS E FETAIS NO DIABETES mellitus GESTACIONAL
}

\author{
Fabiana Lellis Valeri \\ Orientador: Ricardo de Carvalho Cavalli \\ Dissertação de Mestrado apresentada em 31/01/2013
}

O assoalho pélvico é anatomicamente dividido em fáscia endopélvica, diafragma pélvico e diafragma urogenital. O músculo levantador do ânus é considerado a estrutura mais importante na manutenção da estática dos órgãos pélvicos. A gravidez e o parto têm sido implicados no desenvolvimento da disfunção do assoalho pélvico, incluindo o aumento da prevalência de incontinência urinária durante a gravidez e o puerpério. O treinamento dos músculos do assoalho pélvico (TMAP) durante a gravidez tem sido tema de vários estudos que tentam comprovar a sua eficácia na prevenção e tratamento da incontinência urinária e nos resultados do trabalho de parto e parto. E, ainda, considerando que o Diabetes mellitus gestacional é uma importante causa de morbidade e mortalidade perinatal, assim como da morbidade materna, e que a atividade física tem papel importante no manejo clínico, subsidiada por trabalhos evidenciando melhora nos níveis séricos de glicemia. Concomitante ao expressivo número de pesquisas que utilizam protocolos de TMAP durante a gestação como metodologia de escolha e do provável benefício que esse treinamento pode trazer às gestantes, torna-se evidente a necessidade do estudo dos efeitos fetais desse tipo de intervenção. Na literatura, encontram-se trabalhos que avaliaram as repercussões fetais e níveis glicêmicos em gestantes diabéticas, associadas à realização de exercício físico aeróbico, porém constata-se que não existem estudos que contemplaram essa investigação com exercícios específicos do assoalho pélvico, nem tampouco no Diabetes mellitus gestacional. Na presenta análise, realizou-se um estudo do tipo clínico, prospectivo, randomizado e controlado com gestantes de baixo risco e diabéticas. As pacientes foram randomizadas em quatro grupos: dois grupos foram submetidos aos exercícios de treinamento dos músculos do assoalho pélvico através de sessões semanais durante 16 semanas, sendo um grupo de gestantes de baixo risco e o outro as gestantes diabéticas, em contraposição a os outros dois grupos que não realizaram exercícios, também divididos em grupo degestantes de baixo risco e gestantes diabéticas. Os exames ultrassonográficos foram realizados com 28, 32 e 36 semanas gestacionais, sendo avaliados os índices de resistência (IR) e pulsatilidade (IP) das artérias uterina, umbilical e cerebral média, antes e após osexercícios. Na análise estatística foi utilizado o modelo de regressão linear com efeitos mistos (efeitos aleatórios e fixos). Este procedimento foi realizado através do software SAS® 9.0, utilizando a PROC MIXED. Foram incluídas 18 pacientes no grupo exercício e 21 pacientes no grupo controle, dentre as gestantes de baixo risco, e 7 pacientes no grupo exercício e 13 pacientes no grupo controle, dentre as gestantes diabéticas. As comparações das médias dos índices dopplervelocimétricos do grupo exercício no Diabetes melllitus gestacional entre as avaliações antes e após exercício não mostraram diferenças significativas nos fluxos da circulação uteroplacentária, feto placentária e fetal. E, ainda, comparando as médias dos índices dopplervelocimétricos da artéria cerebral média fetal, umbilical e uterinas entre as gestantes de baixo risco e diabéticas após o exercício e nos grupos sem exercício, também não mostraram diferença significativa. Permite-se inferir com o presente estudo que a realização de exercícios de treinamento dos músculos do assoalho pélvico durante a gravidez no Diabetes mellitus gestacional não altera IP e IR das artérias uterinas, umbilical e cerebral média nas idades gestacionais de 28, 32e 36 semanas.

\section{AVALIAÇÃO DOS ÍNDICES DE IMPEDÂNCIA DAS ARTÉRIAS UTERINAS ASSOCIADOS A FATORES DE RISCOO INFLUENCIANDO O DESENVOLVIMENTO DE HIPERTENSÃO ARTERIAL NA GESTAÇÃO}

\author{
Luiz Augusto Beltramin Martins \\ Orientador: Prof. Dr. Ricardo de Carvalho Cavalli \\ Dissertação de Mestrado apresentada em 25/02/2013
}

A hipertensão gestacional e a pré-eclâmpsia são causas importantes de morbidade perinatal. Neste estudo propomos avaliar o aumento do risco relativo para o desenvolvimento de síndromes hipertensivas gestacionais, baseado na avaliação de gestantes entre 20 e 25 semanas, correlacionando os achados desta ocasião com o desfecho gestacional. Foi realizado estudo de coorte prospectivo de conveniência, tendo avaliadas 1.417 pacientes nesta idade gestacional e, posteriormente, 1306 destas foram identificadas ao nascimento. Identificado aumento do risco relativo relacionado ao Índice de Pulsatilidade das artérias uterinas em 2,69 (IC95\% 1,86-3,89). Identificado aumento no risco relativo atribuído a: idade materna acima de 35 anos (2,8; IC95\% 1,58-5,03); paridade maior ou igual a 3 (1,68; IC95\% 1,17-2,40); hipertensão arterial crônica $(5,35$; IC95\% 4,18-6,85) e obesidade, com aumento progressivo do risco relativo de acordo com o grau: sobrepeso, grau 1, 2 e obesidade mórbida $(2,58 ; 3,06 ; 5,84$ e 7,28 respectivamente). 


\title{
EFEITOS DO SISTEMA INTRAUTERINO LIBERADOR DE LEVONORGESTREL SOBRE A FUNÇÃO ARTERIAL DE MULHERES SAUDÁVEIS
}

\author{
Rebecca Pontelo Barboza \\ Orientador: Profa. Dra. Carolina Sales Vieira Macedo \\ Dissertação de Mestrado apresentada em 26/02/2013
}

Introdução: Em mulheres com morbidades, a presença do estrogênio nos contraceptivos pode trazer riscos inaceitáveis para a saúde, que não ocorrem quando esses compostos contem apenas progestagênio, os quais podem ser uma opção. O objetivo deste estudo foi avaliar os efeitos do sistema intrauterino liberador delevonorgestrel (SIU-LNG) sobre a função e estrutura arterial de mulheres saudáveis durante seis meses e comparar com o que ocorre com o uso do contraceptivo oral contendo etinilestradiol.

Sujeitos e Métodos: Foi realizado um estudo longitudinal, prospectivo, não-randomizado, aberto e controlado (quasi-experimental) no qual foram avaliados marcadores ecográficos de avaliação arterial (função e estrutura). As pacientes estavam sem tratamento hormonal há pelo menos dois meses e nenhuma delas tinha qualquer doença sistêmica. Foi iniciado o uso de um contraceptivo oral combinado (COC) 30mcg de EE/150 mcg de LNG ou SIU-LNG. O grupo controle recebeu métodos não hormonais (DIU de cobre ou preservativo masculino). As variáveis foram avaliadas antes e após seis meses do uso dos contraceptivos. Foram avaliados pela ultrassonografia os marcadores da estrutura e função endotelial (medida da dilatação mediada por fluxo da artéria braquial, medida da espessura da íntima-média e o índice de rigidez da carótida). As medidas antropométricas avaliadas foram o peso, o índice de massa corpórea, a cintura, a pressão arterialsistólica (PAS) e diastólica (PAD).

Resultados: Foram incluídas 72 mulheres, sendo 21 no grupo do contraceptivo combinado oral (COC) (30 mcg de etinilestradiol / 150 mcg de levonorgestrel), 30 no grupo do SIU-LNG e 21 que optaram por métodos não hormonais (DIU de cobre ou condom), após terem sido preenchidos os critérios de inclusão/exclusão. A dilatação mediada por fluxo (DMF) das usuárias de COC reduziu-se 29\%, enquanto os demais grupos (SIU-LNG e de métodos não-hormonais) houve apenas uma redução discreta de 5\%. Além disso, houve queda de 3\% da PAS média em usuárias do COC enquanto os demais grupos houve um discreto, porém, significativo, aumento (ambos em torno de 2\%). A PAD média teve uma redução de 4\% nas usuárias do COC, a qual se mostrou significativa frente ao aumento de $2 \%$ na PAD de usuárias de métodos não hormonais. As demais variáveis não se diferiram entre os grupos.

Conclusão: O SIU-LNG não tem efeitos deletérios na função e estrutura arterial de mulheres jovens, contrariamente ao contraceptivo oral combinado que causou uma redução na DMF. A ausência de EE, bem como a dose menor de LNG, pode ter contribuído para estas diferenças.

\section{AVALIAÇÃO DO HISTÓRICO OBSTÉTRICO, INFECÇÕES GENITO-URINARIAS E COMPRIMENTO DO COLO UTERINO COMO FATORES DE RISCO PARA NASCIMENTO PRÉ-TERMO}

\author{
Francisco Javier Alvarez Camayo \\ Orientador: Prof. Dr. Ricardo de Carvalho Cavalli \\ Dissertação de Mestrado apresentada em 01/03/2013
}

O objetivo do presente estudo foi avaliar a correlação entre o histórico obstétrico, as infeções gênito-urinarias e o comprimento do colo uterino como fatores de risco para o parto pré-termo. Foi realizado um estudo tipo coorte, prospectivo, cego, avaliando 1370 gestantes na cidade de Ribeirão Preto com idade gestacional entre 20 e 25 semanas. Realizouse anamnese clinica para a identificação do histórico obstétrico obtendo informação da idade materna, paridade e antecedente de parto pré-termo. Foi praticada ultrassonografia endovaginal para a avaliação do colo uterino segundo as diretrizes da Fetal Medicine Foundation (FMF). Foram coletadas amostras de urina e conteúdo cervico-vaginal com o objetivo de estabelecer a presença de infecção gênito-urinaria concomitante. $\mathrm{O}$ acompanhamento das gestantes permitiu determinar a idade gestacional ao nascimento. A correlação entre o histórico obstétrico, a presença de infecção, o comprimento do colo uterino e a idade gestacional ao nascimento foi realizada mediante o calculo do Risco Relativo das diferentes variáveis. Das 1370 mulheres grávidas avaliadas, 133 (9,7\%) cursaram com parto pre-termo espontâneo (nascimento <259 dias), sendo que $14(10,5 \%)$ dos partos pre-termo ocorreram em mulheres menores de 19 anos, 105 (79\%) em mulheres entre $19 \mathrm{e}$ 35 anos, e 14 (10,5\%) em mulheres maiores de 35 anos. A distribuição das gestantes segundo o comprimento do colo mostrou que houve predomínio de mulheres com o colo cervical maior o igual a $2,5 \mathrm{~cm} 1308$ (95,8\%), em relação àquelas 
com colo cervical entre 2 e 2,49 cm 42 (3,1\%) e com colo uterino menor ou igual a $2 \mathrm{~cm} 15$ (1,1\%). O estudo microbiológico determinou que no grupo das mulheres que cursaram com parto pre-termo, em 8, 17 e 16 mulheres cresceu Mycoplasma hominis, Ureaplasma urealyticum e outras bactérias respectivamente. Das 133 mulheres que cursaram com parto pre-termo espontâneo observou-se que 15 apresentavam cervicometria $<2,5 \mathrm{~cm}, 3$ tiveram o comprimento do colo uterino inferior a $2 \mathrm{~cm}, 3$ inferior a $1,5 \mathrm{~cm}$ e em 2 mulheres foi aferido como inferior a $1 \mathrm{~cm}$. A identificação de gestantes de alto risco para parto pré-termo e a sua vez de fatores de risco modificáveis, pode diminuir a incidência do parto pré-termo.

Embora até o momento não exista um teste padrão de ouro para a predição do parto pré-termo, este estudo confirma que a medida do comprimento do colo uterino é um bom preditor isolado, melhorando a predição quando se leva em consideração a presença de outros fatores de risco como as infecções cervico-vaginais.

\title{
Imunologia Básica e Aplicada
}

\section{Schistosoma mansoni: CARACTERIZAÇÃO MOLECULAR DA PROTEÍNA VESICULAR INTEGRAL DE MEMBRANA DE 36KDA (VIP36) NAS DIFERENTES FASES DO CICLO EVOLUTIVO}

\author{
Alice Maria de Magalhães Ornelas \\ Orientador: Prof. Dr. Vanderlei Rodrigues \\ Dissertação de Mestrado apresentada em 18/02/2013
}

Por décadas, pesquisas em esquistossomose tem focado no entendimento da biologia do desenvolvimento do parasito, na composição do tegumento e nos produtos excretados/secretados pelos ovos, esquistossômulos e vermes adultos para o desenvolvimento de novas drogas ou vacinas. A proteína vesicular integral de membrana de 36 kDa (VIP36) é uma proteína descrita como lectina do tipo-L em animais, que participa do transporte intracelular na via secretória de proteínas ligadas à manose e pode estar localizada na membrana plasmática. Em 2007, foi observada a expressão gênica diferencial da VIP36 em fêmeas adultas em relação a machos adultos. S. mansoni possui um intenso sistema de vesículas e transporte de proteínas para a superfície. Além disso, os produtos excretados/secretados pelos ovos ou larvas estão expostos ao sistema imune do hospedeiro. Dessa forma, a caracterização do gene SmVIP36 nas fases do ciclo evolutivo do parasito torna-se importante para um melhor entendimento da relação parasito-hospedeiro e para desvendar seu potencial para o desenvolvimento de uma vacina. Com este objetivo, primeiramente realizamos a análise in silico da SmVIP36 para: recuperar a sequência gênica em banco de dados, identificar a região codificadora e avaliar a organização genômica do gene, recuperar a sequência predita de aminoácidos para identificar domínios conservados e homologia entre seus ortólogos, reforçada pela análise filogenética; e predizer a estrutura terciária em 3D. Depois, estimamos os níveis de expressão do transcrito e os níveis de proteína da SmVIP36 nas diferentes fases do ciclo de vida do $S$. mansoni por PCR quantitativo e Western Blotting, respectivamente. A análise in silico revelou que a SmVIP36 além de conter um domínio lectínico tipo-L, também apresenta uma dobra jellyroll em sua estrutura terciária 3D, característica de lectinas tipo-L, e contem três cavidades hidrofóbicas, as quais sugerimos conferir estabilidade à dobra jellyroll. Também foi observado que seu CRD contém aminoácidos que se ligam diretamente ao íon cálcio, sugerindo que a ligação da SmVIP36 à glicoproteínas seja cálcio dependente. A sequência predita de aminoácidos da SmVIP36 em relação ao seus ortólogos em outros organismos é conservado. Entretanto, a análise filogenética revela que a SmVIP36 obedece à evolução das espécies, formando clusters mais próximo com $S$. japonicum, e cluster mais distante com seu hospedeiro definitivo Homo sapiens. Este resultado, aliado à predição da localização celular da SmVIP36, a qual mostra a probabilidade de estar ancorada à membrana plasmática, levanos a acreditar que esta proteína apesar de conservada em relação à proteína humana, pode ser usada como alvo terapêutico ou de vacina contra a esquistossomose. Quando os níveis de expressão gênica no ciclo foram analisados, observamos um aumento significativo nas fases de ovo, esquistossômulos e fêmeas adultas. Já os níveis proteicos estão aumentados nas fases de ovos, cercárias, esquistossômulos e vermes adultos. Estes resultados sugerem que a SmVIP36 participe na intensa atividade secretória do envelope do ovo e de proteínas glicosiladas do tegumento e é importante nestes estágios do parasito que interagem com o hospedeiro. Um outro papel que tem sido descrito para a VIP36 em outros organismos é a sua possível participação no controle de qualidade. Desta forma submetemos vermes adultos a diferentes condições de estresse que induzem ao acúmulo de proteínas mal dobradas no citosol e no RE. Em seguida, pudemos observar um aumento dos níveis de transcrito e proteicos de SmVIP36 sugerindo papel no controle de qualidade. 


\title{
ANÁLISE DA EXPRESSÃO GÊNICA POR microarrays DE CÉLULAS-TRONCO HEMATOPOÉTICAS E MESENQUIMAIS DE PACIENTES COM ESCLEROSE MÚLTIPLA
}

\author{
Gislane Lelis Vilela de Oliveira \\ Orientador: Prof. Dr. Eduardo Antônio Donadi \\ Tese de Doutorado apresentada em 22/02/2013
}

As células-tronco hematopoéticas (CTHs) e estromais mesenquimais multipotentes (CTMs) isoladas da medula óssea vêm sendo utilizadas como fonte autóloga no tratamento de doenças autoimunes, como a esclerose múltipla (EM). As CTHs dão origem a todas as células dos sistemas hematopoético e imunológico e as CTMs possuem propriedades imunomoduladoras pela liberação de fatores solúveis e interação célula-célula. Existem trabalhos que sugerem que as doenças autoimunes sejam provenientes de defeitos intrínsecos nas células-tronco precursoras da medula óssea. Com o intuito de avaliar se as CTHs e CTMs de pacientes com EM possuem alterações intrínsecas, o objetivo geral deste trabalho foi avaliar o perfil de expressão gênica diferencial por microarrays de CTHs e CTMs de pacientes com EM, além de avaliar o perfil de expressão gênica de CTMs após o transplante autólogo de CTHs e a capacidade imunomoduladora in vitro das CTMs de pacientes. As CTHs e CTMs foram isoladas da medula óssea de pacientes com EM e doadores saudáveis, após consentimento informado. As CTHs foram isoladas por colunas imunomagnéticas e as CTMs foram isoladas por gradiente de densidade e submetidas à caracterização morfológica, imunofenotípica e capacidade de diferenciação em adipócitos e osteócitos. O RNA das CTHs e CTMs foi extraído e purificado e o perfil de expressão gênica foi avaliado por microarrays, utilizando hibridações em lâminas contendo 44.000 sondas. A capacidade imunomoduladora das CTMs de pacientes e controles foi avaliada por ensaios de cocultivo com linfócitos alogênicos e as citocinas foram quantificadas no sobrenadante por CBA flex e ELISA. Este estudo foi aprovado pelo comitê de ética do Hospital das Clínicas da Faculdade de Medicina de Ribeirão Preto. Os resultados mostraram que as CTHs de pacientes possuem perfis de expressão gênica diferentes dos controles, com 2.722 genes diferencialmente expressos, envolvidos em vias de sinalização importantes para manutenção/ proliferação das CTHs e diferenciação em linhagens específicas durante a hematopoese. Dentre essas sinalizações estão incluídas as vias da apoptose, Wnt, Notch, mTOR, PI3K/Akt e Ca/NFAT, sugerindo que as CTHs de pacientes com EM possuam alterações intrínsecas que podem estar relacionadas com a patogenia da doença autoimune. As CTMs isoladas de pacientes com EM exibiram aparência senescente e reduzida expressão de marcadores imunofenotípicos. Com relação à expressão gênica, as CTMs de pacientes possuem perfil diferente das CTMs controle, sendo detectados 618 genes diferencialmente expressos, incluindo genes relacionados à sinalização FGF, HGF, sinalização de moléculas de adesão e moléculas envolvidas nos processos de imunorregulação, como IL10, IL6, TGFB1, IFNGRI, IFNGR2 e HGF. O perfil de expressão gênica das CTMs de pacientes pós-transplante assemelhou-se ao perfil das CTMs prétransplante. Ensaios de cocultivo de CTMs com linfócitos alogênicos mostraram que as CTMs de pacientes possuem capacidade antiproliferativa reduzida em relação às CTMs controle, e ainda, secreção reduzida de TGF- $\beta$ e IL-10 no sobrenadante das coculturas. Esses dados sugerem que as CTMs isoladas de pacientes com EM possuam alterações fenotípicas, transcricionais e funcionais. Embasados nesses achados, concluímos que as CTHs e as CTMs de pacientes com EM possuem alterações intrínsecas que podem estar relacionadas com a patogenia da doença. Uma vez que as CTMs sejam células com grande potencial terapêutico para controle da EM em pacientes refratários aos tratamentos convencionais, as alterações encontradas sugerem que CTMs de doadores saudáveis sejam mais adequadas em aplicações clínicas.

\section{ANÁLISE DA EXPRESSÃO GÊNICA GLOBAL DE CÉLULAS ESTROMAIS MESENQUIMAIS E DE CÉLULAS TRONCO HEMATOPOÉTICAS ISOLADAS DA MEDULA ÓSSEA DE PACIENTES COM DIABETES mellitus DO TIPO 1}

\author{
Kalil William Alves de Lima \\ Orientadora: Profa. Dra. Kelen Cristina Ribeiro Malmegrim de Farias \\ Dissertação de Mestrado apresentada em 25/02/2013
}

O diabetes mellitus do tipo 1 (T1D) é uma doença autoimune mediada por células T e caracterizada pela destruição seletiva das células $\beta$ pancreáticas produtoras de insulina. Células estromais mesenquimais (MSCs) e células tronco hematopoéticas (HSCs) são os principais componentes do nicho hematopoético na medula óssea. Estas células vêm 
sendo utilizadas nos últimos anos em transplantes autólogos para tratamento do T1D. O objetivo geral do presente trabalho foi avaliar o perfil de expressão gênica global de MSCs e HSCs de pacientes com T1D e compará-lo com células isoladas de indivíduos saudáveis através da técnica de microarray e programas específicos de bioinformática. As MSCs e HSCs foram isoladas da medula óssea de pacientes com T1D antes e após o tratamento com imunossupressão em altas doses seguida pelo transplante autólogo de células tronco hematopoéticas (AHSCT). As MSCs apresentaram valor elevado de expressão absoluta de diversas moléculas potencialmente relacionadas com suas funções de suporte à hematopoese. MSCs de pacientes diabéticos apresentaram perfil de expressão gênica global distinto das isoladas de indivíduos saudáveis, com hiper-regulação da sinalização via proteína $\mathrm{G}$ e hiporregulação da atividade transcricional. O receptor $\beta 3$ adrenérgico, assim como a sinalização simpática, foram hiper-expressos nas células dos pacientes. Genes que codificam moléculas que suportam a hematopoese e regulados pelo sistema nervoso simpático, VCAM1 e CXCL12, foram hiporregulados em nossa análise. Após o AHSCT, houve atenuação do perfil de expressão diferencial das MSCs dos pacientes, entretanto elas permaneceram com hiperatividade da sinalização via proteína $\mathrm{G}$ e déficit da atividade transcricional. As HSCs apresentaram altos níveis de expressão absoluta de diversas integrinas e receptores de citocinas e fatores de crescimento, potencialmente relacionados com funções na hematopoese. HSCs de pacientes com T1D apresentaram perfil de expressão gênica global distinto das de indivíduos saudáveis, com hiper-regulação de genes associados com a atividade transcricional. Os fatores de transcrição TCFL2 e p53, que têm papel fundamental na regulação do ciclo celular das HSCs, foram diferencialmente expressos entre as HSCs de pacientes diabéticos e controles. Assim, nossos resultados de expressão gênica global apontaram alterações intrínsecas nas HSCs e MSCs de pacientes diabéticos que podem estar relacionadas com a falha terapêutica dos transplantes autólogos. A implicação dessas alterações no desenvolvimento e patogênese do T1D permanece desconhecida e a realização de ensaios funcionais poderá esclarecer o significado biológico das mesmas.

\title{
ESTUDO DA PARTICIPAÇÃO DE IL-22 NA REGULAÇÃO DA RESPOSTA INFLAMATÓRIA E REPARO TECIDUAL CUTÂNEO
}

\author{
Monique Thaís Costa Fonseca \\ Orientadora: Prof. Dra. Cristina Ribeiro de Barros Cardoso \\ Dissertação de Mestrado apresentada em 08/03/2013
}

A cicatrização de feridas cutâneas é um processo complexo onde há a participação de vários tipos celulares e tecidos, sendo dependente de mecanismos sincronizados de reação inflamatória, sinalização celular e reparo tecidual. Esta última etapa do processo ocorre após modulação adequada da resposta inflamatória inicial para o posterior fechamento da lesão, permitindo assim que a pele restabeleça suas funções de proteção. Neste contexto supõe-se que, dentre vários mediadores, a citocina IL-22 esteja envolvida neste processo, uma vez que a mesma exerce papel importante na modulação da resposta imunológica e, supostamente, no reparo tecidual. Portanto, o objetivo deste trabalho foi estudar do papel de IL-22 na regulação da resposta inflamatória e reparo tecidual cutâneo. Para tal, camundongos C57BL/6, selvagens (wild type, WT) ou deficientes de IL-22 (IL-22 $2^{--}$) foram submetidos à indução de feridas cutâneas. Observou-se que a ausência de IL-22 causou atraso no fechamento das lesões e que houve perda de peso independente de IL-22 pós-cirurgia, sugerindo que a extensão das feridas poderia afetar o metabolismo sistêmico dos animais. O infiltrado leucocitário dos tecidos lesados foi avaliado por histologia e a quantificação de células inflamatórias por ensaios enzimáticos mostrou que na ausência de IL-22 houve exacerbação da resposta caracterizada principalmente por células polimorfonucleares como neutrófilos. Além disso, na ausência de IL-22 observou-se acúmulo persistente de células T CD4 ${ }^{+}$e T CD8 ${ }^{+}$nos linfonodos drenantes da lesão e essas células tiveram atividade proliferativa diminuída em relação aos leucócitos de camundongos WT. Em adição, camundongos IL-22-/- apresentaram aumento de marcadores de regulação como CD45RB ${ }^{\text {low }}$, CD73, FR4, GITR e CTLA-4 nas populações de células T $\mathrm{CD} 4^{+} \mathrm{CD} 25^{+}$e $\mathrm{CD} 4^{+} \mathrm{CD} 25^{-}$presentes nos linfonodos drenantes das lesões, sendo que houve aumento também do número de linfócitos $\mathrm{CD} 4^{+} \mathrm{CD} 25{ }^{-}$Foxp $3^{+} 120$ horas após a realização das feridas. Em contrapartida, a molécula PD-1 estava diminuída na ausência de IL-22 em animais naive ou com 120h de lesão, sugerindo que IL-22 exerce importante influência sobre esta molécula reguladora. Finalmente, esses resultados sugeriram que IL-22 é essencial para o rápido fechamento das feridas cutâneas. Ainda, na ausência dessa citocina há perda da homeostasia entre resposta efetora e reguladora em um contexto de inflamação de pele, resultando em imunidade inata e adaptativa descontroladas pós-lesão. 


\title{
IDENTIFICAÇÃO DE CASCATAS GÊNICAS COM BASE NA MODULAÇÃO TRANSCRICIONAL DE CÉLULAS SANGUÍNEAS MONONUCLEARES PERIFÉRICAS DE PACIENTES COM DIABETES Mellitus DO TIPO 1
}

\author{
Thais Cristine Arns \\ Orientador: Prof. Dr. Geraldo Aleixo da Silva Passos Júnior \\ Dissertação de Mestrado apresentada em 15/03/2013
}

O diabetes mellitus do tipo 1 (DM1) é uma doença autoimune crônica, durante a qual as células beta pancreáticas, responsáveis pela secreção de insulina, são seletivamente destruídas. O desenvolvimento desta doença é uma consequência da predisposição genética combinada a fatores ambientais largamente desconhecidos e eventos estocásticos. Neste trabalho foi proposta a comparação da expressão gênica transcricional em grande escala (transcriptoma) entre amostras de pacientes de DM1 e controles, obtidas a partir de células mononucleares do sangue periférico (PBMCs). As alterações resultantes na expressão gênica causada pela doença podem ser amostradas em PBMCs, uma vez que as células imunes efetoras estão presumivelmente em equilíbrio com a população celular circulante. A fim de identificar alterações na expressão gênica, foram utilizados métodos analíticos como a tecnologia de microarrays e o cálculo do coeficiente de correlação de Pearson, sendo possível observar aumento ou diminuição na expressão gênica e também a magnitude desta mudança. Além disso, foi realizada análise de grupos gênicos (gene sets ou GSA), método baseado na significância de conjuntos gênicos pré-definidos, ao invés de genes individuais. Este procedimento é mais adequado para análise de uma doença poligênica, tal como o DM1. A análise de GSA possibilitou a seleção de genes envolvidos, por exemplo, nas seguintes vias: cascata de I-kappaB kinase/NF-kappaB, regulação da via de sinalização do receptor de TGF- $\beta$, regulação da cascata de JAKSTAT e via de sinalização mediada por citocinas e quimiocinas, das quais podem ser identificados marcadores transcricionais. A análise imparcial do transcriptoma de PBMCs permitiu a identificação de gene sets e genes associados ao DM1, seu perfil de expressão preferencial em tipos celulares do sistema imune e seus padrões de modulação.

\section{ESTUDO EVOLUTIVO DOS HANTAVÍRUS E DESENVOLVIMENTO DE UMA RT-PCR QUANTITATIVA EM TEMPO REAL PARA DETECÇÃO DO VÍRUS ARARAQUARA}

\author{
William Marciel de Souza \\ Orientador: Prof. Dr. Luiz Tadeu Moraes Figueiredo \\ Dissertação de Mestrado apresentada em 28/03/2013
}

O gênero Hantavírus são membros da família Bunyaviridae são vírus emergentess associados a roedores que podem infectar o homem causando graves doenças. Nas Américas, os Hantavírus causam uma síndrome pulmonar e cardiovascular (SPCVH) com alta letalidade. Cerca de 1600 casos de SPCVH já foram notificados no Brasil causando mais de 600 óbitos. Sete espécies de Hantavírus são conhecidas no Brasil incluindo o vírus Araraquara que circula nas regiões de cerrado do país associado ao roedor Necromys lasiurus. Esta Dissertação, possui 2 partes que versam sobre: o desenvolvimento de uma RT-PCR em tempo real para detecção e quantificação do Hantavírus Araraquara e um estudo filogenéticos sobre a evolução dos Hantavírus. Portanto, mostramos as etapas para o desenvolvimento de uma one-step RT-PCR em tempo real SYBR Green I para Hantavírus Araraquara que mostrou-se específica para o gênero e capaz de detectar até 10 cópias por $\mathrm{mL}$ de RNA viral na amostra. Como segunda parte deste trabalho, realizamos um estudo filogenético utilizando algoritmos bayesianos, com 190 sequências completas do gene da nucleoproteína, oriundas de 30 países durante um período de 25 anos (1985-2010) que encontravam-se disponíveis no GenBank (NCBI). Baseando-se em uma taxa média de 6.8 x 10-4 (2.5 x 10-4 - 1 x 10-3) substituições nucleotídicas por sítio/ano, foi possivel inferir que os Hantavírus teriam aproximadamente 1917 anos. O processo de dispersão dos Hantavírus pelo mundo teria ocorrido há aproximadamente 500 anos, e a introdução destes vírus nas Américas teria ocorrido há 549 anos (95\% HPD 1555-341 anos), via América Central ou Mexico, originando os Hantavírus adaptados aos roedores da subfamília Neotominae, e pelo Brasil surgindo há 406 anos (95\% HPD 1150-250 anos) os Hantavírus associados a roedores da subfamília Sigmodontinae, e posteriormente dispersaram para todo o continente sulamericano. O trabalho contribui de forma relevante para o diagnóstico das infecções por Hantavírus com a one-step RT-PCR em tempo real SYBR Green I e também, contribui para o entendimento da filogenia e história destes vírus, oferecendo subsídios ao entendimento sobre como teria ocorrido o espalhamento dos Hantavírus pelo mundo. 


\title{
Neurologia
}

\section{CLASSIFICAÇÃO DA FUNÇÃO MOTORA GROSSA E HABILIDADE MANUAL DE CRIANÇAS COM PARALISIA CEREBRAL: DIFERENTES PERSPECTIVAS ENTRE PAIS E TERAPEUTAS}

\author{
Daniela Baleroni Rodrigues Silva \\ Orientadora: Profa. Dra. Luzia Iara Pfeifer \\ Tese de Doutorado apresentada em 04/03/2013
}

O Gross Motor Function System Expanded and Revised (GMFCS E \& R) e o Manual Ability Classification System (MACS) têm sido amplamente utilizados na pesquisa e na prática clínica como complemento ao diagnóstico da paralisia cerebral (PC). Ambos consistem em cinco níveis, sendo que o nível V indica maior limitação funcional. O objetivo deste estudo foi realizar o processo de tradução e adaptação transcultural do GMFCS E \& R e MACS, avaliar a confiabilidade inter-avaliadores (entre terapeutas e entre terapeutas e pais) e intraavaliadores (terapeutas) acerca dos sistemas de classificação (GMFCS E \& R e MACS) e verificar a influência de fatores relacionados à criança (tipo de PC) e aos pais (escolaridade, renda, ocupação e idade) na confiabilidade entre terapeutas e pais. Participaram 100 crianças com PC, que eram acompanhadas pelo serviço de neurologia ou de reabilitação de um hospital terciário no interior paulista na faixa etária entre 4 a 18 anos, e seus pais. Para a aplicação dos sistemas de classificação realização da tradução e adaptação transcultural do GMFCS E \& R, seguiram-se seis estágios: tradução, síntese das traduções, retrotradução para língua de origem, comitê de análise, submissão aos autores e pré-teste. A coleta de dados foi feita por dois terapeutas com diferentes níveis de experiência na área de neuropediatria. Os terapeutas classificaram a função motora grossa da criança (GMFCS E \& R) através da observação direta (controle de cabeça, tronco, transferências, mobilidade) e os pais responderam ao GMFCS Family Report Questionnaire, onde deveriam selecionar uma opção, dentre cinco, correspondente ao nível motor da criança. Quanto à habilidade manual (MACS), os terapeutas observaram a criança manipulando objetos (brinquedos, alimentação, vestuário) e obtiveram informações dos pais. Os pais realizaram a classificação da habilidade manual da criança com base na leitura do folheto explicativo do MACS. Foram realizadas filmagens das observações das crianças para avaliação da confiabilidade intra-avaliadores (terapeutas), após um mês da avaliação inicial. Utilizou-se o coeficiente Kappa (k) para avaliação da confiabilidade inter-avaliadores (entre terapeutas e entre terapeutas e pais) e intra-avaliadores (terapeutas) acerca do GMFCS E \& R e MACS e o teste do qui-quadrado (x2) para verificar a associação entre os fatores relacionados à criança e aos pais. Após realizados os seis estágios referentes à tradução e adaptação transcultural do GMFCS E \& R e MACS, as versões em português foram aprovadas pelos autores. Em relação à confiabilidade interavaliadores (AV1 e AV2), obteve-se concordância quase perfeita para o GMFCS E \& R e MACS (K=0,902 e 0,90 respectivamente), assim como intra-avaliadores, obtendo-se concordância quase perfeita para ambos avaliadores acerca do GMFCS $\mathrm{E} \& \mathrm{R}(\mathrm{k}=1,00)$ e MACS (K=0,958 para AV1 e $\mathrm{K}=0,833$ para AV2). Em relação à confiabilidade entre terapeutas e pais, esta foi substancial para GMFCS E \& $\mathrm{R}(\mathrm{K}=0,716)$ e considerável para MACS $(\mathrm{K}=0,368)$. Em relação ao GMFCS E \& $\mathrm{R}$, verificou-se que o porcentual de discordâncias no grupo de pais que não trabalha fora é significativamente superior ao porcentual de discordância de quem trabalha fora $($ x $2=4,79 ; \mathrm{p}=0,03)$, quando comparada à classificação do terapeuta. Maior freqüência de pais classificaram as crianças como severamente limitada, comparada à classificação do terapeuta (x 2 =4,26; p= 0,04). Em relação ao MACS, verificou-se que as discordâncias entre terapeutas e pais foram significativamente superiores nas crianças de 4 a 6 e 6 a 12 anos do que em relação às crianças de 12 a 18 anos ( $p=0,05)$, assim como pais na faixa etária de 20 a 30 anos discordaram significativamente mais do terapeuta ( $\mathrm{p}=0,04)$. É importante considerar a influência de fatores ambientais no desempenho típico da criança com PC em relação à função motora grossa e habilidade manual. Portanto, embora terapeutas e pais apresentem diferentes perspectivas em relação a tais aspectos, por julgarem diferentes contextos como referência (pais consideram o desempenho em casa, escola, ambientes externos; o terapeuta, o ambiente clínico), os dois pontos de vista necessitam ser apreciados conjuntamente. Concluise que as versões traduzidas para o português - Brasil do GMFCS E \& R, GMFCS Family Report Questionnaire são confiáveis para classificar crianças com PC por pais e terapeutas. 


\title{
Oftalmologia, Otorrinolaringologia e Cirurgia de Cabeça e Pescoço
}

\author{
CORRELAÇÃo ENTRE SENSIBILIDADE LARÍNGEA E PENETRAÇÃO/ASPIRAÇÃO TRAQUEAL \\ EM DISFAGIA OROFARÍNGEA PÓS-ACIDENTE VASCULAR ENCEFÁLICO
}

\author{
Suely Mayumi Motonaga Onofri \\ Orientador: Prof. Dr. Roberto Oliveira Dantas \\ Tese de Doutorado apresentada em 14/01/2013
}

A disfagia orofaríngea pode ter diversas etiologias. Dentre as doenças neurológicas no adulto, o acidente vascular encefálico (AVE) é a causa mais comum dos distúrbios da deglutição. Vários métodos são utilizados para o diagnóstico da disfagia orofaríngea. Ressalta-se que o exame da nasofibroscopia da deglutição, além de determinar sua presença e gravidade, informa sobre as condições da sensibilidade na laringe. A integridade da sensibilidade na laringe é um elemento fundamental para o desenvolvimento de uma deglutição segura, isto é, sem riscos de complicações pulmonares. Este estudo tem o objetivo de correlacionar a presença ou ausência da sensibilidade laríngea com os achados da nasofibroscopia da deglutição (escape precoce, resíduos em faringe, penetração laríngea e aspiração traqueal) na oferta de três consistências alimentares (pastosa, líquida engrossada e líquida). Foi realizado um estudo clínico transversal com 98 indivíduos adultos pós-AVE isquêmico, com média de 68,1 anos de idade, e tempo de lesão do AVE com média de 22,6 meses. Todos os indivíduos realizaram a nasofibroscopia da deglutição e foram submetidos à avaliação da sensibilidade, por meio de toque, com a extremidade do endoscópio na região das aritenoides e pregas ariepiglóticas. Após a avaliação da sensibilidade, foram oferecidas três consistências alimentares coradas em azul e avaliados os parâmetros do exame, como: escape precoce, resíduos em faringe, penetração laríngea e aspiração traqueal. Para o estudo da correlação entre os achados endoscópicos e a presença ou ausência da sensibilidade laríngea, foi aplicado o coeficiente de correlação linear de Spearman. Dos resultados obtidos, pode-se afirmar que houve correlação negativa e estatisticamente significativa entre os parâmetros de resíduos na faringe, penetração laríngea e aspiração traqueal e a sensibilidade da laringe, com todas as consistências testadas. Na ausência da sensibilidade laríngea, os achados de resíduos em faringe, penetração e aspiração traqueal foram mais frequentes. Não se observou resultado estatisticamente significativo para a presença de escape precoce e sensibilidade na laringe. A sensibilidade na mucosa da faringe e laringe é um elemento imprescindível para uma deglutição segura, pois sua deficiência, associada à atividade motora alterada, pode causar disfagia neurogênica nos indivíduos pós-AVE.

\section{EXPRESSÃO DOS ANTÍGENOS CÂNCER-TESTICULARES MAGE-A, MAGE-C1, GAGE E NY-ESO-1 EM DOENÇAS BENIGNAS E MALIGNAS DA GLÂNDULA TIREOIDE}

\author{
Daniel Hardy Melo \\ Orientador: Prof. Dr. Rui Celso Martins Mamede \\ Tese de Doutorado apresentada em 04/02/2013
}

Introdução: Recentes avanços na biologia molecular do câncer de tireoide têm sido aplicados no desenvolvimento de novos marcadores de diagnóstico, visando a diferenciação entre lesões da tireoide que apresentam características microscópicas que dificultam a interpretação histológica. No entanto, a utilização destes avanços, quer como indicadores de prognóstico ou mesmo na diferenciação entre lesões benignas e malignas, ainda está dentro dos limites da experimentação e pesquisa. Neste estudo, intencionou-se estudar a expressão imuno-histoquímica de um painel de antígenos câncertesticulares em amostras de tecido tireoideo para avaliar seu potencial como marcadores diagnóstico e prognóstico.

Materiais e Métodos: Trata-se de estudo retrospectivo, caso-controle, com 117 pacientes operados no Hospital das Clínicas da Faculdade de Medicina de Ribeirão Preto da Universidade de São Paulo e no Hospital A.C. Camargo, no período de 1962 a 2011, sendo 22 bócios coloides, 9 adenomas foliculares, 9 carcinomas foliculares, 28 carcinomas papilíferos, 28 carcinomas medulares, 8 carcinomas pouco diferenciados e 13 carcinomas anaplásicos. Os critérios de inclusão foram: dados clínicos e macroscópicos disponíveis, representação adequada da lesão, processamento histológico apropriado e disponibilidade de blocos de parafina em boas condições. Foram realizadas análises dos dados clínicos, anatomopatológicos e a imuno-histoquímica do painel de antígenos câncer-testiculares.

Resultados: No grupo de doenças benignas não foi observada imunomarcação dos antígenos. Nas amostras de 
carcinoma papilífero e folicular, a expressão de Multi MAGE-A foi de 8,1\%, GAGE foi de 10,8\%, e de MAGE-C1 e NY-ESO1 foi de 2,7\%, mas não houve relação significante entre a expressão gênica com as variáveis estudadas e a sobrevida. Entre os casos de carcinoma medular, a expressão de Multi MAGE-A foi de 42,9\%, do MAGE-C1 foi 46,5\%, do GAGE foi 92,9\% e de NY-ESO-1 foi 3,6\%. Nestes casos houve significância estatística entre a expressão de GAGE e as variáveis sexo e estadiamento clínico. Nas amostras de carcinoma pouco diferenciado e anaplásico, a expressão de Multi MAGE-A foi de 61,8\%, MAGE-C1 57,1\%, GAGE 66,7\% e NY-ESO-1 14,4\%. Nestes casos houve significância estatística entre a expressão de GAGE e a variável sexo.

Discussão: O padrão de expressão tumor-específico de proteínas é extremamente atraente para o campo da Oncologia, permitindo seu uso, não somente como indicadores de diagnóstico e prognóstico, mas também como um potencial candidato ao tratamento imunoterápico. Poe meio do emprego individual ou na forma de painel, os antígenos MAGE-A, MAGE-C1, GAGE e NY-ESO-1 poderão ser potenciais alvos para o desenvolvimento de vacinas contra o câncer, mesmo se para isso houver a necessidade de terapia epigenética.

Conclusão: Houve expressão dos antígenos MAGE-A, MAGE-C1 e GAGE em mais de 40\% nos carcinomas medulares; mais de 50\% nos carcinomas pouco diferenciados e anaplásicos. A expressão do GAGE nos carcinomas medulares e indiferenciados foi de $92,9 \%$ e $66,7 \%$, respectivamente, e houve correlacão com as variáveis sexo e estadiamento clínico avançado. Os dados do presente estudo sugerem que a utilização dos antígenos câncer-testiculares estudados fornece informação adicional no diagnóstico e prognóstico dos cânceres de tireoide, especialmente o carcinoma medular, pouco diferenciado e anaplásico.

\title{
RESPOSTA PROLIFERATIVA E INFLAMATÓRIA DA GLÂNDULA LACRIMAL EM QUATRO MODELOS DE RATOS
}

Elisio Bueno Machado Filho

Orientador: Prof. Dr. Eduardo Melani Rocha

Tese de Doutorado apresentada em 01/03/2013

Objetivo: O objetivo deste estudo foi avaliar a glândula lacrimal (GL) e superfície ocular (SO) em resposta à ablação parcial (G1), transplante alogênico (G2), denervação (G3) e indução imune (G4).

Métodos: Ratos Wistar machos com oito semanas de idade foram submetidos aos seguintes procedimentos na GL direita: G1) ablação parcial; G2) ablação parcial e transplante alogênico de GL; G3) denervação e G4) indução inflamatória por injeção de GL homogeneizada em base da cauda. Nos três primeiros grupos, o olho esquerdo foi o controle ( $\mathrm{n}=5-10 /$ grupo). Os animais foram anestesiados e avaliados em lâmpada de fenda, pelo teste do fenol vermelho e por citologia de impressão. As GL foram removidas e processadas para histologia e western blot para comparar a expressão de antígeno nuclear de proliferação celular (PCNA) e caspase-3 ativada depois de um mês e dois meses.

Resultados: A observação em lâmpada de fenda revelou sinais de inflamação e neovascularização da córnea, principalmente no G2, seguido pelos G4, G1 e G3. O teste do fenol vermelho não diferiu entre os grupos, após um mês e dois meses ( $p>0,05)$. O peso da GL foi aproximadamente a metade no G1 e G2 depois de um e dois meses em relação ao controle ( $\mathrm{p}=0,0386$ para um mês e $\mathrm{p}<0,0001$ para dois meses). No G4, hipotrofia e dilatação das glândulas de Meibômio (GM) foram observadas. A expressão de caspase- 3 foi significativamente maior no G2 e G4 e em um mês (p=0,0242 e 0,0177, respectivamente) e nos G3 e G4 em dois meses ( $p=0,0095$ e 0,0043, respectivamente), já o PCNA não apresentou diferenças.

Conclusões: Em ratos, a regeneração espontânea ou por meio de transplante alogênio da GL não pode ser observada após dois meses. Além disso, em três dos quatro modelos a lesão de GL estendeu-se para a GM ou córnea.

\section{PROTEÇÃO AUDITIVA CONTRA O TRAUMA ACÚSTICO PELO CONDICIONAMENTO AUDITIVO COM GENTAMICINA}

\author{
Alex Strose \\ Orientador: Prof. Dr. José Antonio Apparecido de Oliveira \\ Tese de Doutorado apresentada em 08/03/2013
}

O fenômeno do condicionamento auditivo consiste da pré-exposição de um agente potencialmente traumático ao sistema auditivo em níveis não lesivos no intuito de estimular mecanismos, ainda não totalmente esclarecidos, de proteção contra uma apresentação traumática posterior. O primeiro agente utilizado, tanto na fase de condicionamento quanto traumática, foi o ruído. Posteriormente, este fenômeno foi testado, com sucesso, na maioria das vezes, com os mais 
diversos agentes. Entretanto, grande parte dos autores utiliza o mesmo fator para condicionar e causar o trauma. O objetivo do presente estudo foi verificar se o condicionamento auditivo com fator diverso do apresentado para o trauma é efetivo. Para isto, foram formados três Grupos: Grupo A1- controle para o trauma acústico: exposição a ruído branco centrado em $4 \mathrm{kHz}$ a $110 \mathrm{~dB}$ por 72 horas; Grupo A2- controle para condicionamento com gentamicina: administração da droga na dose de $30 \mathrm{mg} / \mathrm{kg} /$ dia por 30 dias consecutivos e Grupo A3- condicionamento com gentamicina na mesma posologia do Grupo (A2) e posterior exposição a ruído nos mesmos moldes do Grupo (A1). Foram realizadas análises morfológicas e funcionais uma hora depois de cessado o estímulo ao trauma acústico para avaliar a efetividade do condicionamento. As primeiras foram feitas por Microscopia Eletrônica de Varredura (MEV) e as últimas por Potenciais Evocados Auditivos de Tronco Encefálico (PEATE), estimando-se os limiares eletrofisiológicos antes e após cada tratamento. As variáveis estudadas foram a ausência ciliar e os limiares auditivos. Os resultados mostraram que o condicionamento com gentamicina foi efetivo em proteger morfologicamente as células ciliadas, uma vez que o grupo condicionado apresentou valor significativamente menor de lesão ciliar, 10,8\% e 22,9\% respectivamente (p-valor 0,0146); entretanto, não foi efetivo em preservar a funcionalidade do sistema auditivo, já que não houve diferença estatisticamente significativa na mudança de limiares entre o grupo que foi condicionado e o que recebeu apenas o trauma acústico. Concluiu-se que o condicionamento com fator diverso ao usado no trauma é efetivo, sugerindo que ambos devem promover mecanismos intrínsecos semelhantes de autoproteção, entretanto, ele parece não evitar, precocemente, as alterações funcionais desencadeadas pelo trauma acústico.

\title{
Ortopedia, Traumatologia e Reabillitação
}

\section{EFEITOS DO ENSAIO DE TORÇÃO POR ALTA VELOCIDADE EM OSSO CORTICAL: ESTUDO EXPERI- MENTAL COM RATOS SEDENTÁRIOS TREINADOS EM PLATAFORMA VIBRATÓRIA}

\author{
Jorge Caolo Imori Junior
}

Orientador: Prof. Dr. Antonio Carlos Shimano

Dissertação de Mestrado apresentada em 06/02/2013

Introdução: O sedentarismo é considerado uma epidemia silenciosa e primária de inúmeras outras patologias consequentes da inatividade física, que por sua vez, causam comprometimento na plenitude de uma vida saudável. A comodidade da vida moderna, onde o homem é o centro de todas as atenções. Chamado de "Antropocentrismo" e tudo é desenvolvido para proporcionar facilidades sem grandes esforços no cotidiano. Na prática de atividade física, como complemento surge à praticidade das plataformas vibratórias, sendo uma alternativa de atividade física para evitar os efeitos negativos da imparidade funcional, atrofia dos músculos, fraturas e fragilidade do sistema esquelético.

O objetivo deste trabalho foi avaliar ratos saudáveis, induzidos ao sedentarismo e ao treinamento físico em plataforma vibratória a $60 \mathrm{~Hz}$, durante a fase de crescimento e desenvolvimento no período pós-natal com 21 dias até atingir a fase adulta com 112 dias, para avaliar a interferência do ambiente nos fatores de crescimento das propriedades mecânicas do osso cortical no ensaio de alta velocidade.

Metodologia: (40) ratos Wistar distribuídos em 4 grupos (n=10): Grupo A (livre controle) 21 dias + 91 dias de idade, Grupo B (livre treinado a $60 \mathrm{~Hz}$ ) 21 dias de idade + treinamento por 91 dias. Grupo C (sedentário controle) 21 + 91 dias, Grupo D (sedentários treinados a $60 \mathrm{~Hz}$ ) 21 dias + 91 dias. Avaliação dos efeitos do sedentarismo e da vibração sobre o animal ocorreu por meio da determinação da densidade mineral óssea total, após o período de treinamento os animais sofreram a eutanásia e os fêmures, foram dissecados e submetidos à análise das microestruturas pela densitometria em sub-regiões do osso e ensaio mecânico de torção por alta velocidade.

Resultados: A densidade mineral corpo total houve diferença estatística entre os grupos: LC e L 60 hz apresentaram valores maiores que os SC e S $60 \mathrm{~Hz}$. Entretanto a densidade mineral óssea analisada no fêmur não houve diferença estatística entre os grupos. No ensaio mecânico nas diferentes propriedades mecânicas, houve diferença estatística, os animais sedentários apresentaram prejuízo comparado aos livres e treinado por vibração.

Conclusão: O sistema de confinamento sedentário em gaiolas "reduzidas" durante a fase de crescimento e desenvolvimento do animal foi eficiente e influenciou na perda das propriedades mecânicas dos grupos sedentários, neste caso o ambiente teve predominância superior ao treinamento por vibração. A plataforma vibratória foi eficiente nos animais do grupo livre em melhorar as propriedades mecânicas dos fêmures. Ambos os grupos experimentais sedentários e livres treinados em plataforma vibratória apresentaram resultado final satisfatório. 


\title{
EFEITOS DO EXERCÍCIO DE ALTO IMPACTO EM OSSOS OSTEOPÊNICOS: ESTUDO EXPERIMENTAL EM RATAS OVARIECTOMIZADAS
}

\author{
Rodrigo Okubo \\ Orientador: Prof. Dr. Antonio Carlos Shimano \\ Tese de Doutorado apresentada em 27/02/2013
}

A osteoporose é uma condição de perda da microarquitetura óssea normal, levando a diminuição da densidade óssea e fragilidade do osso. O tratamento desta condição visa reduzir o risco de fraturas futuras e deve ser adaptado para o paciente individualmente. A ênfase deve ser no reconhecimento precoce e tratamento dos pacientes com alto risco de fraturas. Há alguma evidência de que exercícios de alto impacto sejam particularmente benéficos para aumentar a massa óssea. Desta maneira, o objetivo deste trabalho foi avaliar ratas ovariectomizadas submetidas a um programa de treinamento físico de alto impacto, prévio e após a instalação da osteopenia. Para tal, oitenta ratas Wistar de 10 semanas de idade, foram divididas em programas de prevenção $(\mathrm{p})$ e de tratamento $(\mathrm{t})$ e, subdivididas nos oito grupos seguintes $(\mathrm{n}=10)$ : (prevenção) Sham sedentário (Sp), Ovariectomizado sedentário (Op), Sham Treinado (STp), e Ovariectomizado Treinado (OTp); (tratamento) Sham sedentário (St), ovariectomizado sedentário (Ot), Sham treinado (STt), e Ovariectomizado Treinado (OTt). Um período de exercício de 12 semanas foi introduzido, em que os ratos dos grupos treinados saltavam 20 vezes/dia, 5 dias/semana, da altura de $40 \mathrm{~cm}$. Ao final do período experimental, foram realizadas as seguintes análises: dosagem de hormônio folículo estimulante (FSH) e de marcadores ósseos: osteocalcina, OPG e RANK-L, densitometria por absorciometria de raios X de dupla energia (DXA), histomorfometria óssea e testes biomecânicos. Testes estatísticos específicos foram realizados, utilizando-se nível de significância de 5\%. Os grupos de prevenção e tratamento mostraram resultados semelhantes. Os grupos ovariectomizados apresentaram valores mais elevados de FSH (p <0,05) e massa corpórea $(\mathrm{p}<0,05)$. O treinamento de salto aumentou significativamente a densidade mineral óssea (DMO) do fêmur e da vértebra L5 ( $\mathrm{p}<0,05)$. Força máxima e rigidez dos ossos fêmur e vértebra L5 nos grupos exercitados foram maiores do que nos grupos sedentários ( $\mathrm{p}<0,05)$. Dosagens de osteocalcina também apresentaram valores mais elevados nos grupos treinados $(\mathrm{p}<0,05)$. Animais ovariectomizados apresentaram menores valores de RANK-Le maiores de OPG. Parâmetros histomorfométricos BV/TV, Tb.Th, Tb.N, OV.BV, OS.BS, Ob.S/BS, O.Th, N.Ob/B.Pm foram maiores nos grupos treinados, além disso os parâmetros que indicam reabsorção (Tb.Sp e N.Oc/B.Pm, ES/BS, Oc.S/BS) foram menores nestes grupos (p $<0,05)$. Os resultados sugerem que o treinamento de salto pode ter benefícios potenciais para tratar e prevenir a osteopenia ocasionada pela ovariectomia.

\section{Patologia}

\section{O ESTUDO DO NF-KB E DA SURVIVINA NA PROGRESSÃO DO CÂNCER COLORRETAL}

\author{
Mariângela Ottoboni Brunaldi \\ Orientador: Prof. Dr. Alfredo Ribeiro-Silva \\ Tese de Doutorado apresentada em 25/03/2013
}

O câncer colorretal (CCR) é importante causa de morte no Brasil, representando a segunda causa de morbimortalidade por câncer nas regiões Sudeste e Sul. Foi uma das primeiras neoplasias malignas a ter modelo de carcinogênese identificado. Os objetivos deste trabalho foram avaliar a expressão do NF- $\kappa$ B e da survivina na progressão do CCR, sua relação com alvos moleculares envolvidos na sobrevivência celular [proibitina, fator de necrose tumoral (TNFR1), p53, $\beta$ catenina]; invasão (metaloproteinases 2 e 9- MMP), angiogênese (fator de crescimento endotelial vascular VEGF) e apoptose (caspase 3 e método do Túnel). Trata-se de estudo retrospectivo baseado na análise histopatológica de dezoito casos de adenomas com displasia de alto (AG) e baixo grau (BG), respectivamente; dez casos de adenocarcinoma bem, moderado e pouco diferenciado, respectivamente, nove casos de lesões serrilhadas e nove biópsias colorretais (controle) selecionados aleatoriamente no Serviço de Patologia do Hospital das Clínicas da Faculdade de Medicina de Ribeirão Preto da Universidade de São Paulo, no período de 2000 a 2009. Foram construídos arranjos de matriz tecidual para representar os casos de adenocarcinomas e cinco casos de adenomas $>1 \mathrm{~cm}$ de diâmetro. A detecção do NF- $\kappa \mathrm{B}$ foi realizada pelo 
método de Southwestern imunoistoquímica. Avaliou-se a expressão imunoistoquímica da survivina, proibitina, TNFR1, p53, $\kappa$ catenina, MMPs 2 e 9, VEGF, caspase 3 e Túnel. Não observamos expressão imunoistoquímica do NF-кB em 70\% dos casos de adenocarcinomas, em $72 \%$ dos adenomas AG e em $89 \%$ das lesões serrilhadas; a marcação foi positiva em $66 \%$ e $56 \%$ dos casos de adenoma de BG e controle, respectivamente. Expressões da survivina, proibitina citoplasmática, TNFR1, p53, MMP 2 e 9 foram crescentes na sequência adenoma-carcinoma, sem aparente modulação pelo NF- $\kappa B$. A survivina suprimiu ação da caspase 3, exceto nos adenomas BG e controle, com baixos níveis de apoptose ao túnel. Lesões serrilhadas e controle apresentaram baixa expressão do TNFR1 e da proibitina citoplasmática, ausência de marcação da p53 e MMPs 2 e 9, exceto um caso controle. Identificou-se marcação nuclear da proibitina nos adenocarcinomas pouco diferenciados, adenomas AG e BG. A expressão da p53 relacionou-se ao grau de displasia nos adenomas e à desregulação da survivina. Observou-se expressão citoplasmática e nuclear da $\beta$ catenina nos adenocarcinomas, adenomas AG e BG. As lesões serrilhadas exibiram expressão citoplasmática em $44 \%$ dos casos. O grupo controle exibiu expressão preservada da $\beta$ catenina. Identificou-se expressão do VEGF nos adenocarcinomas, relacionada à perda de diferenciação celular, presença de metástases,

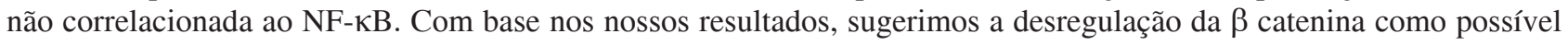

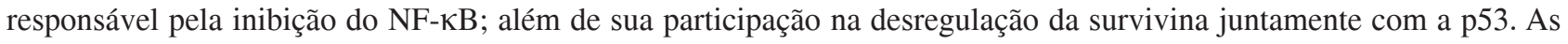
lesões serrilhadas não exibiram indícios de inibição do NF- $\kappa B$ pela $\beta$ catenina. A survivina, devido propriedades antiapoptóticas, emerge como potencial alvo terapêutico no tratamento do CCR, confirmando estudos anteriores.

\title{
Saúde da Criança e do Adolescente
}

\section{ANÁLISE DO SISTEMA IGF-IGFBPS EM CRIANÇAS PORTADORAS DO VÍRUS DA IMUNODEFICIÊNCIA HUMANA (HIV)}

\author{
Marcelo Amaral Ruiz \\ Orientador: Prof. Dr. Carlos Eduardo Martinelli Junior \\ Tese de doutorado apresentada em 21/01/2013
}

Os objetivos deste trabalho foram descrever os parâmetros de crescimento de crianças impúberes contaminadas verticalmente pelo HIV, descrever as concentrações séricas dos principais componentes do sistema IGF-IGFBPs, de citocinas pró-inflamatórias e avaliar a sensibilidade insulínica nestas crianças em dois momentos diferentes de controle da doença.

De 2007 a 2009 foi realizado este estudo observacional prospectivo em uma coorte de crianças com HIV com avaliações antropométricas e laboratoriais nos tempos 0,6 meses e 1 ano. Crianças controle impúberes, hígidas, acompanhadas em serviço de puericultura e pareadas por sexo e idade foram avaliadas clinica e laboratorialmente em uma única oportunidade e dados referentes à velocidade de crescimento (VC) obtida de seus prontuários. Trinta e sete crianças com HIV (22 do sexo masculino) e trinta crianças controle (17 do sexo masculino) completaram o estudo.

As concentrações séricas de IGF-I, IGF-II, IGFBP-1 e IGFBP-3 foram determinadas por ELISA. As concentrações séricas de IGFBP-1 e IGFBP-3 também foram determinadas por Western ligand blotting (WLB) juntamente com a IGFBP2 e a IGFBP-4. Glicemia foi determinada por reação enzimática, Insulina foi determinada por RIE e os índices de HOMA-â [20 x insulina (iIU/mL) / glicemia (mmol/L) - 3,5] e de HOMA-IR [glicemia (mmol/L) x insulina $(\mathrm{iIU} / \mathrm{mL}) / 22,5]$ calculados. As concentrações séricas da interleucina-2 (IL-2), interleucina-6 (IL-6) e do fator de necrose tumoral alfa (TNFa) foram determinadas por Luminex ${ }^{\circledR}$. A quantificação de carga viral (CV) foi determinada por bDNA.

Definimos que as crianças com HIV que apresentaram, durante todo o período da pesquisa, um maior número de amostras com $\mathrm{CV}<5.000$ cópias/ $\mathrm{mL}$ obtiveram controle clínico-laboratorial adequado durante a pesquisa (CCLA), portanto as crianças com HIV que apresentaram um número maior de amostras com CV >5.000 cópias $/ \mathrm{mL}$ obtiveram controle clínico-laboratorial inadequado durante a pesquisa (CCLI). As determinações séricas foram realizadas em duas 9

ostras de cada criança com HIV, propositalmente as amostras com menor (melhor controle da doença) e maior (pior controle da doença) carga viral. Definimos ainda que, dentre as amostras utilizadas para as determinações séricas, aquelas com $\mathrm{CV}<5.000$ cópias $/ \mathrm{mL}$ eram amostras com bom controle da doença e aquelas com CV >5.000 cópias $/ \mathrm{mL}$ eram amostras com mau controle da doença.

O índice de massa corporal foi semelhante entre as crianças com HIV e as crianças controle. A estatura das crianças com HIV tanto em CCLA como em CCLI estava abaixo da média para idade e foi inferior à estatura das crianças controle 
$(\mathrm{p}<0,001)$. VC das crianças com HIV em CCLI foi inferior que a das crianças controle ( $\mathrm{p}<0,05)$, a VC das crianças com HIV em CCLA não apresentou diferenças com nenhum dos grupos.

Pela análise pareada, não identificamos diferenças em nenhum dos itens estudados neste trabalho para as crianças com HIV, estando elas em momento de melhor ou pior controle da doença. Esse achado deve ser avaliado com cuidado, pois quando definimos momento de melhor ou pior controle da doença, levamos em consideração a menor e a maior CV, independentemente dos seus valores absolutos e, para algumas crianças, esses valores eram próximos, o que pode dificultar a identificação de diferenças.

Quando comparamos apenas as amostras em bom controle da doença ( $\mathrm{CV}<5.000$ cópias $/ \mathrm{mL})$ com as amostras apenas em mau controle da doença $(\mathrm{CV}>5.000$ cópias $/ \mathrm{mL})$ e com as amostras das crianças controle identificamos que as concentrações séricas de IGF-I, IGF-II e de IGFBP-3 nas amostras em bom e em mau controle foram semelhantes entre si e inferiores as dos controles. As concentrações séricas de IGFBP-1 e de IGFBP-4 foram semelhantes nos três grupos. As concentrações de IGFBP-2 foram maiores nas amostras em mau controle que nas em bom controle, ambas não apresentaram diferenças com as crianças controle. Consideramos esses achados um desequilíbrio do sistema IGF-IGFBPs que reduz a atividade estimuladora do crescimento dos IGFs.

Em relação à glicemia de jejum, não houve diferenças entre os grupos, porém as concentrações de insulina e consequentemente os valores do índice de HOMA-IR foram inferiores nas amostras em mau controle que nas dos controles. O índice de HOMA-â foi inferior nas amostras em mau controle que nas dos controles.

Em relação às citocinas pró-inflamatórias, tanto as concentrações de IL-6 como de TNFa foram semelhantes nas amostras em bom e em mau controle da doença e ambos os grupos apresentaram concentrações superiores às crianças controle, demonstrando que existe um processo inflamatório permanente nas crianças com HIV, estando elas em bom ou em mau controle da doença. As concentrações de IL-2 foram semelhantes entre os três grupos. Como a IL-2 é produzida principalmente pelos linfócitos T CD4+, alvo principal da infecção pelo HIV, esse achado indica que tais células estão com a função comprometida nestas crianças.

Neste trabalho, demonstramos que as crianças com HIV apresentam um padrão deficitário de crescimento em relação às crianças hígidas e que esse padrão de crescimento pode ser explicado por alterações no sistema IGF-IGFBPs presentes nas crianças com HIV tanto em bom como em mau controle da doença. Tais alterações caracterizam-se principalmente pela redução das concentrações dos componentes que estimulam o crescimento (IGF-I, IGF-II e IGFBP-3) e por concentrações desproporcionalmente elevadas dos componentes que diminuem a biodisponibilidade e a bioatividade dos IGFs (IGFBP-1, IGFBP-2 e IGFBP-4). Tais alterações podem ser decorrência de resistência à atuação do GH pelo processo inflamatório permanente presente nestas crianças ou ainda de comprometimento da própria função dos hepatócitos.

\section{AVALIAÇÃO ANTROPOMÉTRICA DE CRIANÇAS COM DOENÇAS HEPÁTICAS CRÔNICAS}

\section{Patrícia Volpon Santos Atique}

Orientador: Prof. Dr. Carlos Eduardo Martinelli Junior

Dissertação de Mestrado apresentada em 21/01/2013

O objetivo do estudo foi avaliar dados antropométricos (índice de massa corpórea, estatura e velocidade de crescimento) de crianças com doenças hepáticas colestáticas e não colestáticas, comparando os diferentes grupos de doenças e suas possíveis interferências no desenvolvimento pôndero-estatural destes pacientes.

Método: Foi realizado estudo descritivo retrospectivo em coorte de 46 pacientes, crianças, com doença hepática colestática e não colestática, seguidas em ambulatório de hepatologia pediátrica. Destes, 16 eram portadores de hepatopatias colestáticas e os outros 30, de não colestática. Os critérios de inclusão foram idade entre 1 - 10 anos, de ambos os sexos, classificação de Child-Pugh modificada A ou B com tratamento estabelecido. A partir da revisão dos prontuários foram coletados dados de peso e altura, em 2 avaliações com intervalo de tempo entre 1 e 10 anos, sendo calculados IMC e velocidade de crescimento. Foram calculados os parâmetros escore desvio padrão (EDP) da estatura, do IMC e da velocidade de crescimento. Para análise estatística, foram usados os testes de Mann-Whitney, Tpareado e Fischer, e significância estatística foi assumida com $\mathrm{p} \leq 5 \%$.

Resultados: Dos 46 pacientes com doenças colestáticas e não colestáticas, apenas 4 apresentaram diagnóstico de baixa estatura (EDP estatura <-2DP) e apenas um apresentou comprometimento do estado nutricional (EDP IMC $<-2$ DP). 
Na avaliação inicial, 2 pacientes encontravam-se acima de 2 DP para velocidade de crescimento, e 16 na avaliação final. Avaliando o grupo de pacientes com doenças colestáticas, 2 pacientes apresentaram EDP acima de 2 DP na avaliação inicial e 5 na avaliação final, e no grupo com doenças não colestáticas apenas 1 paciente encontrava-se com EDP > 2 DP contra 11 na avaliação final. Quanto ao estado nutricional, na avaliação inicial do IMC nenhum apresentava EDP <-2 DP, enquanto 1 paciente apresentava EDP <-2 DP na avaliação final, e 4 apresentavam-se com EDP > 2 DP na avaliação inicial, mas nenhum deles manteve este EDP na avaliação final. Quando se compara os 2 grupos (colestáticos e não colestáticos) observa-se que o EDP IMC entre a avaliação inicial e final dos pacientes colestáticos mostrou uma redução discretamente maior ( $0,75 \pm 1,2$ DP início para $0,19 \pm 0,75$ DP final) do que nos pacientes com doença não colestática.

Conclusão: Os pacientes pediátricos portadores de doenças hepáticas crônicas (colestáticas e não colestáticas) apresentam bom perfil de crescimento e ganho ponderal quando em fases iniciais de lesão hepática (sem cirrose) e doença controlada, seguindo particularidades em cada grupo.

\title{
PARTO CESÁREA E OUTROS FATORES DE RISCO PARA ADIPOSIDADE AUMENTADA NO ADULTO JOVEM
}

\author{
Denise Nascimento Mesquita \\ Orientador: Prof. Dr. Marco Antonio Barbieri \\ Tese de doutorado apresentada em 31/01/2013
}

Introdução: Fatores ambientais, genéticos, fisiológicos e comportamentais tem sido identificados como sendo de risco para sobrepeso e obesidade. A medida mais utilizada para o diagnóstico do sobrepeso/obesidade é o índice de massa corporal, que é uma medida de adiposidade total. Outros indicadores de adiposidade são menos utilizados, porém como o acúmulo de gordura central tem se mostrado como o melhor preditor de morbidade, ultimamente medidas de adiposidade central também tem sido utilizadas. Recentemente o parto cesáreo (PC) foi identificado como fator associado com maior risco de obesidade avaliada pelo índice de massa corporal. A associação dessa via de parto com os demais indicadores de adiposidade aumentada tem sido pouco investigada.

Objetivos: 1) Avaliar se o PC e outros fatores da mãe, da gestação e do recém-nascido são fatores de risco para adiposidade aumentada na vida adulta jovem; 2) Avaliar se hábitos de vida e fatores socioeconômicos do adulto jovem são fatores de risco para adiposidade aumentada na vida adulta.

Metodologia: Foram estudados 2063 jovens entre 23 e 25 anos de idade, participantes da coorte de nascimentos de Ribeirão Preto, SP, Brasil, de 1978/79. As medidas antropométricas usadas como indicadores de adiposidade foram: circunferência de cintura (CC), razão cintura-altura (RCA), razão cintura-quadril (RCQ), prega cutânea tricipital (PCT) e prega cutânea subescapular (PCS). A associação entre PC, fatores referentes à gestação e do adulto jovem com os indicadores de adiposidade aumentados foram analisados por meio de regressão de Poisson com ajuste robusto da variância, com intervalo de confiança de $95 \%$. Foram realizados dois modelos: modelo1-ajustado por variáveis do nascimento; modelo 2ajustado por variáveis do nascimento e da idade adulta.

Resultados: A prevalência de cesariana nessa coorte foi de 32\%. As prevalências de CC, RCA, RCQ, e as distribuições, PCT e PCS foram 32,1\%, 33,0\%, 15,2\%, 10\% e 9,4\%, respectivamente. As variáveis que se mantiveram como fator de risco para pelo menos uma das medidas de adiposidade aumentadas após o ajuste por variáveis do nascimento foram: PC (associado a todas as medidas); menor escolaridade materna (CC, RCA, PCT e PCS); sexo feminino (PCT e PCS) e peso ao nascer (CC). Após o ajuste por variáveis do nascimento e as confundidoras do adulto, ficaram como fator de risco o PC (todas as medidas); sexo feminino (PCT e PCS); peso ao 12 nascer (CC); paridade (RCQ); e idade (CC). Como fatores de proteção no modelo 1 tivemos o sexo feminino (CC, RCA e RCQ); tabagismo materno durante a gestação (PCT e PCS); no modelo 2 ficou o sexo feminino (CC, RCA e RCQ); tabagismo materno durante a gestação (PCS); o adulto jovem sem companheiro (CC, RCA, PCT e PCS); adulto com maior escolaridade (CC, RCA, RCQ e PCT); renda familiar mais elevada (CC, RCQ e PCT); e cor da pele (CC).

Conclusão: Além dos fatores biológicos, ambientais e socioeconômicos, o PC se mostrou como fator de risco para a adiposidade central e periférica aumentada em adultos jovens, quando comparados aos nascidos por parto vaginal. Possível mecanismo para explicar essa associação seriam mudanças na microbiota intestinal induzidas pela cesariana, aumentando o risco de obesidade mais tarde na vida. 


\title{
DURAÇÃO DA EXCREÇÃO DO CITOMEGALOVIRUS (CMV) NA SALIVA E NA URINA DE CRIANÇAS COM INFECÇÃO CONGÊNITA PELO CMV EM UMA POPULAÇÃO COM ALTA SOROPREVALÊNCIA MATERNA
}

\author{
Camila dos Santos Alvim
}

Orientador: Prof. ${ }^{a}$ Dr. ${ }^{a}$ Aparecida Yulie Yamamoto

Dissertação de Mestrado apresentada em 15/02/2013

Justificativas: Embora já seja conhecido que crianças com infecção congênita pelo CMV geralmente excretam o vírus por anos, na urina e na saliva, os estudos disponíveis foram realizados em países desenvolvidos. Ainda não é conhecido se a duração da excreção do CMV é semelhante em crianças infectadas congenitamente, em populações com elevada soroprevalência do CMV.

Objetivos: Os objetivos deste estudo consistiram em determinar e comparar a duração da excreção do CMV na saliva e urina de crianças com infecção congênita sintomática e assintomática ao nascer e verificar a frequência da recorrência de excreção viral em ambos os sítios.

Métodos: 99 recém-nascidos identificados por meio de uma triagem neonatal como infectados congenitamente pelo CMV foram, acompanhados desde o nascimento até uma mediana de 57 meses (24-93 meses). A duração da excreção do CMV na saliva e na urina foi considerada a média entre a idade da criança no momento da última detecção do DNA do CMV e a idade da primeira amostra negativa. O clareamento do CMV na saliva e na urina foi documentado com pelo menos 2 testes negativos. A duração da excreção do CMV d" 2 anos na saliva e d" 3 anos na urina foi considerada como excreção curta, e a duração $>2$ anos na saliva e $>3$ anos na urina foi considerada excreção longa. A mediana de testes por criança foi de 11 testes (6-20) na saliva e de 12 testes (6-21) na urina. Os dados foram analisados pelo método de sobrevida de Kaplan-Meier e pelo modelo de regressão de Cox, censurando os dados das crianças que não tiveram clareamento do CMV na sua última avaliação.

Resultados: Dentre as 99 crianças, 57 (57\%) eram do sexo masculino e 42 (43\%) eram do sexo feminino, 10 (9,7\%) eram sintomáticos ao nascimento e $21(20,4 \%)$ apresentavam restrição de crescimento intra-uterino. A mediana da duração da excreção do CMV foi de 32 meses (variação: 11-65) e de 56 meses (variação:18-93), na saliva e na urina, respectivamente. Períodos intermitentes de clareamento viral ou recorrência da excreção viral foram observados em 24/83 (29\%) e em 27/57 (47\%) crianças, na saliva e na urina, respectivamente. A duração curta e prolongada da excreção CMV foi observada em 47/ 99 (47.4\%) versus 52/99 (52.6\%) na saliva e 20/89 (22.5\%) versus 69/89 (77.5\%) na urina. A excreção do CMV foi mais prolongada na urina em relação à saliva (HR:5,03; IC95\%:3,54-7,15). Não houve associação entre sintomas ao nascimento e a duração da excreção na saliva (HR:1,49;IC95\%: 0,74-3,00) ou com a duração da excreção do CMV na urina (HR:1,95;IC95\%:0,82-4,65).

Conclusões: A duração da excreção do CMV em crianças com infecção congênita deste estudo foi similar ao observado em países desenvolvidos. Os achados de uma duração mais curta da excreção viral na saliva e maior frequência de recorrência viral na urina sugerem que a resposta imunológica do hospedeiro para o controle da replicação do CMV pode ser mais eficiente nas glândulas salivares.

\section{ANÁLISE DA EXPRESSÃO DE ANTÍGENOS DE HISTOCOMPATIBILIDADE CLASSE II EM TUMORES ADRENOCORTICAIS DE CRIANÇAS E ADOLESCENTES}

Fabíola de Arruda Leite

Orientador: Prof. Dr. Carlos Alberto Scrideli

Dissertação de Mestrado apresentada em 01/03/2013

Introdução: Dentre os tumores raros da infância, temos os adrenocorticais que na literatura mundial apresenta incidência de $0,2 \%$ de todas as neoplasias pediátricas. Nas últimas décadas muitos estudos buscam descobrir os mecanismos que levam ao desenvolvimento destes tumores assim como identificar possíveis marcadores moleculares, a fim de ajudar no diagnóstico e avaliar prognóstico.

Objetivo: Analisar, em tumores adrenocorticais pediátricos, a expressão de 3 antígenos de histocompatibilidade humana (HLA).

Pacientes e Métodos: Os antígenos HLADRA, HLA-DPA e $\boldsymbol{H L A}-D P B 1$ foram analisados por meio de PCR em tempo real quantitativo, em 58 amostras consecutivas de tumor obtidas de crianças com diagnóstico de neoplasia adreno- 
cortical. Destas amostras, 13 foram classificadas como adenomas (escore de Weiss $<3$ ) e 44 como adrenocarcinomas (escore de Weiss e" 3) e 1 não definida. Também foi realizada análise em 10 amostras de tecido adrenal não neoplásico de crianças. Trinta e uma foram analisadas para expressão proteica por imunohistoquímica para HLA-DPA. Na análise estatística foram utilizados os testes de Mann-Whitney e Kruskall-Wallis para avaliar a correlação entre a expressão dos antígenos apresentados e as variáveis clínicas e biológicas das amostras estudadas, e curvas de Kaplan Meier e o teste log rank para estimar a sobrevida livre de eventos em 5 anos e análise multivariada por modelo de regressão de Cox para analisar independência dos fatores prognósticos observados em análise univariada.

Resultados: Os valores de expressão dos antígenos duas vezes abaixo da mediana dos controles não neoplásicos foram considerados como hipoexpressos. Foi observada uma associação significativa entre menores índices de expressão e amostras tumorais com peso e" 100 gramas para os genes $\boldsymbol{H L A}-\boldsymbol{D} \boldsymbol{R A}$ (5,2 "fold", $\mathrm{P}=0,009), \boldsymbol{H L A}-\boldsymbol{D P A}$ (2,44 "fold", $\mathrm{P}=0,013) \boldsymbol{H L A}-\boldsymbol{D P B 1}(2,2$ "fold”, $\mathrm{P}=0,023)$; volume e"200 cm3 e HLA-DRA (4 "fold”, $\mathrm{P}<0,001), \boldsymbol{H L A}-\boldsymbol{D P A}$ (5,27 "fold”, $\mathrm{P}=0,003) \boldsymbol{H L A}-\boldsymbol{D P B} 1$ (4 “fold”, $\mathrm{P}<0,001$ ); e presença de óbito/recidiva e HLA-DRA (7,35 “fold", $\mathrm{P}=0,002), \boldsymbol{H L A}-\boldsymbol{D P A}$ (9,84 "fold", $\mathrm{P}<0,001) \boldsymbol{H L A}-\boldsymbol{D P B 1}$ (5,47 "fold", $\mathrm{P}=0,005)$. Analisando as amostras classificadas com Weiss e"3, a idade também apresentou associação significativa para os genes $\boldsymbol{H L A}-\boldsymbol{D R A}$ (4,9 “fold”, $\mathrm{P}<0,001), \boldsymbol{H L A}-\boldsymbol{D P A}(7,16$ "fold", $\mathrm{P}=0,006) \boldsymbol{H L A}$ DPB1 (3,9 "fold", $\mathrm{P}=0,006)$ Os níveis de expressão dos genes apresenta associação inversa com estadio para os genes HLA-DRA ( $\mathrm{P}=0,009), \boldsymbol{H L A}-D P A(\mathrm{P}=0,017)$ e HLA-DPB1 $(\mathrm{P}=0,037)$. Também houve associação entre a hipoexpressão dos genes e menores taxas de sobrevida livre de eventos em 5 anos para $\boldsymbol{H L A}-\boldsymbol{D R A}(63.6 \pm 8,5 \%$ versus $94.7 \pm 5,1 \%, \mathrm{P}=0,017)$, $\boldsymbol{H L A}-\boldsymbol{D P A}(40 \pm 12,6 \%$ versus $85.7 \pm 6,1 \%, \mathrm{P}<0,001) \boldsymbol{H L A}-\boldsymbol{D P B} 1(62 \pm 8,4 \%$ versus $94.4 \pm 5,4 \%, \mathrm{P}=0,017)$. A análise multivariada por regressão de Cox evidenciou o gene $\boldsymbol{H L A D P A}$ como fator prognóstico independente $(\mathrm{P}=0,012)$, quando analisado em associação com idade, peso e volume tumoral. Resultados semelhantes foram observados quando analisados apenas os casos de carcinoma. Menor marcação por imunohistoquímica foi associada a menor sobrevida $(\mathrm{P}=0.008)$.

Conclusão: Este estudo sugere que a hipoexpressão dos antígenos de histocompatibilidade de classe II (DRA, DPA $\boldsymbol{e}$ DPB1) estão relacionados à presença de doença mais agressiva e prognóstico desfavorável. Nossos dados sugerem que antígenos de classe II podem ser úteis como marcador prognóstico.

\title{
Saúde Mental
}

\section{INVESTIGAÇÃO DE FATORES IMPLICADOS NA DIFERENÇA ENTRE OS SEXOS NO RECONHECIMEN- TO DE EXPRESSÕES FACIAIS: EMOÇÃO DESPERTADA E FASES DO CICLO MENSTRUAL}

\author{
Vinícius Guandalini Guapo \\ Orientador: Profa. Dra. Cristina Marta Del Ben \\ Tese de Doutorado apresentada em 18/01/2013
}

As diferenças entre os sexos e o impacto dos hormônios sexuais no processamento emocional normal e patológico destacam-se na investigação do dimorfismo sexual na frequência, diagnóstico e terapêutica de patologias psiquiátricas. Transtornos depressivos e ansiosos não apenas são mais comuns em mulheres, quando comparadas aos homens, como parecem ser influenciados pelas concentrações hormonais séricas das mulheres em diferentes fases do ciclo reprodutivo. Ao mesmo tempo, o sexo e as concentrações dos hormônios sexuais, mostram influência na função do cérebro em uma diversidade de tarefas cognitivas e emocionais. O reconhecimento de expressões faciais de emoções básicas tem sido visto como função de extrema importância na adaptação social do indivíduo e existem evidências de que esteja relacionado com o desenvolvimento de transtornos psiquiátricos. Já foi demonstrado que esta tarefa é influenciada pelo sexo do indivíduo e seu ambiente hormonal, no entanto, a literatura carece de resposta sobre os mecanismos pelos quais estas diferenças acontecem. Em dois experimentos buscamos maior entendimento de como se dão as diferenças entre os sexos no reconhecimento de expressões faciais de emoções básicas (raiva, asco, medo, tristeza, surpresa e alegria). No experimento 1,33 voluntários saudáveis do sexo masculino e 30 do sexo feminino foram testados quanto à acurácia no reconhecimento de expressões faciais, ao tipo de erro ao realizar esta tarefa e à emoção despertada durante este reconhecimento. No experimento 2, 24 voluntárias saudáveis foram testadas quanto à acurácia no reconhecimento de expressões faciais em três diferentes fases do ciclo menstrual: fase folicular precoce (primeiro ao quinto dia do ciclo), periovulatória (décimo segundo ao décimo quarto dia do ciclo), e lútea (vigésimo primeiro ao vigésimo terceiro dia do ciclo), em delineamento cruzado. Foi realizada dosagem sanguínea de estradiol, progesterona e testosterona ao final de cada sessão experimental, 
com o intuito de confirmar a fase do ciclo das voluntárias e buscar possíveis correlações entre esses hormônios e o processamento de expressões faciais. Utilizou-se análise de contraste na avaliação do desempenho no reconhecimento de todas as emoções básicas com o desempenho no reconhecimento da emoção alegria. No experimento 1, raiva e medo em faces femininas foram reconhecidos com maior acurácia por mulheres, quando comparadas aos homens. Não foram encontradas diferenças significativas entre os sexos quanto à emoção despertada durante a visualização de expressões faciais. O experimento 2 mostrou que o reconhecimento das emoções asco e tristeza em faces masculinas variou de maneira significativa durante as fases do ciclo menstrual. As mulheres na fase lútea obtiveram maior acurácia no reconhecimento de expressões de asco em comparação com a fase folicular precoce, enquanto o desempenho no reconhecimento de tristeza foi maior na fase periovulatória do que na fase lútea. Os resultados sugerem que as diferenças entre homens e mulheres na capacidade de reconhecer emoções não estejam relacionadas à valência da emoção despertada nos indivíduos durante o processamento emocional. A modulação do reconhecimento de expressões faciais pelas fases do ciclo menstrual aponta que este seja um dos fatores implicados nas diferenças entre os sexos nesta tarefa.

\title{
DEPRESSÃO, ESTRESSE PRECOCE, EIXO HIPOTÁLAMO-PITUITÁRIA-ADRENAL E A RESPOSTA TERAPÊUTICA: AVALIAÇÕES PSICOMÉTRICAS E PSICONEUROENDÓCRINAS
}

\author{
Sandra Márcia de Carvalho Tofoli \\ Orientador: Prof. Dr. Mario Francisco Pereira Juruena \\ Dissertação de Mestrado apresentada em 08/03/2013
}

Introdução: A Depressão é uma condição relativamente comum, de curso crônico, recorrente, estando frequentemente associada com incapacitação funcional e comprometimento da saúde física. Entre os fatores associados, encontram-se situações de abuso e negligência, entre outros. O eixo Hipotálamo-Pituitária-Adrenal (HPA) desempenha um papel fundamental na resposta aos estímulos externos e internos, podendo desencadear episódios psiquiátricos em indivíduos predispostos. Além disso, estudos têm corroborado que alterações no funcionamento do eixo HPA estão associadas à gravidade de quadros depressivos e são indicativas de um prognóstico desfavorável.

Objetivo: O objetivo deste estudo foi avaliar pacientes depressivos com presença ou ausência de estresse precoce, identificando as alterações no funcionamento do eixo HPA e a resposta terapêutica.

Metodologia: A amostra foi composta por 30 sujeitos, sendo 20 pacientes depressivos em regime de semi-internação no Hospital Dia do Hospital das Clínicas da FMRP-USP e 10 controles saudáveis. Além disso, os sujeitos do estudo foram divididos em: um grupo de pacientes depressivos $(n=20)$ e controles saudáveis $(n=10)$; um subgrupo de pacientes respondedores $(n=8)$ e não respondedores ao tratamento $(n=8)$; um subgrupo de pacientes deprimidos com presença de Estresse Precoce $(n=13)$, ausência de Estresse Precoce $(n=7)$ e de controles saudáveis $(n=10)$. Os pacientes foram avaliados por meio de Entrevista Clínica de acordo com os critérios diagnósticos do DSM-IV, para a confirmação do diagnóstico. Para avaliação da gravidade dos sintomas depressivos foi aplicada a Escala de Depressão de Hamilton (HAM-D21), sendo incluídos apenas pacientes com HAM-D21 $\geq 17$. Utilizamos também a Escala de Avaliação de Depressão de MontgomeryAsberg (MADRS) para avaliação da resposta terapêutica, sendo considerados respondedores os pacientes que obtiveram uma redução da pontuação da MADRS? 50\% entre a admissão e 60 dias após. A presença de Estresse Precoce foi confirmada através da aplicação do Questionário Sobre Traumas na Infância (CTQ). Foram utilizados também, o Inventário de Depressão de Beck (BDI), o Inventário de Ansiedade de Beck (BAI), a Escala de Ideação Suicida de Beck (BSI), a Escala de Desesperança de Beck (BHS), a Escala Hospitalar de Ansiedade e Depressão (HADS) e a Escala de Impulsividade de Barratt (BIS-11) para a avaliação dos sintomas psiquiátricos. A avaliação endócrina foi realizada através do cortisol salivar, sendo coletado às 22h, ao acordar, 30 e 60 minutos após acordar e às 8h30min na admissão e após 60 dias.

Resultados: Nossos resultados demonstraram uma associação entre a gravidade dos quadros depressivos com o aumento das tentativas de suicídio, do uso abusivo de bebidas alcoólicas e da obesidade, bem como com o aumento dos sintomas de ansiedade, desesperança, impulsividade e da comorbidade com os Transtornos de Personalidade. Encontramos que além desses fatores, a resposta inadequada ao tratamento também pode ser influenciada pela história prévia de Estresse Precoce. Além disso, nossos achados indicaram que a maior gravidade dos pacientes depressivos da nossa amostra se correlacionaram com uma maior atividade do eixo HPA, e este aumento foi associado a níveis mais elevados de cortisol salivar tanto na admissão quanto 60 dias após o tratamento nos pacientes não respondedores. Evidenciamos também que este aumento da atividade do eixo HPA pode ser influenciado pelo Estresse Precoce, uma vez que os pacientes com presença EP apresentaram níveis maiores de cortisol salivar, mesmo após o tratamento. 
Conclusão: Com base nos resultados apresentados, nossos achados apontam para o papel etiológico do eixo HPA na depressão, estando este muitas vezes associado a situações de EP que acarretam em uma maior gravidade dos pacientes e piora da resposta terapêutica. Dessa forma, nossos dados sugerem que a avaliação do eixo HPA possa prever a recorrência da psicopatologia, servindo assim, como um potencial biomarcador na depressão destes pacientes.

\title{
Saúde na Comunidade
}

\section{EVOLUÇÃO DOS INDICADORES MATERNOS INFANTIS, APÓS A PACTUAÇÃO NOS MUNICÍPIOS DE UM COLEGIADO DE GESTÃO REGIONAL PAULISTA}

\author{
Bartira Palin Bortolan Pontelli \\ Orientador: Prof. Dr. Juan Stuardo Yazlle Rocha \\ Dissertação de Mestrado apresentada em 25/01/2013
}

Introdução: No contexto atual, os gestores precisam estar à frente de desafios que busquem superar as dificuldades próprias do Sistema, valendo-se de uma rede regionalizada e hierarquizada de ações e do planejamento em saúde, para melhor qualificação e da gestão, assim, para intensificar o processo de melhoria na Gestão e melhor compreender as necessidades da população,em 2006 foi publicada a Portaria n 399/GM definindo o Pacto pela Saúde, que, dentre outros objetivos valoriza a relação solidária entre gestores, elabora diretrizes e responsabilidades sanitárias com base em indicadores e matas, visando contribuir para o fortalecimento da gestão

Objetivo: O estudo tem o objetivo de descrever a evolução dos indicadores de saúde maternos infantis do Pacto pela Vida, no Colegiado de Gestão Regional Sul - 5 - Barretos no período 2007 a 2010, após da pactuação. Metodologia - O presente estudo foi desenvolvido nos municípios pertencentes ao Colegiado de Gestão Regional Sul - DRS 5 - Barretos, a saber: Monte Azul Paulista, Viradouro, Terra Roxa, Vista Alegre do Alto, Taiaçu, Taquaral, Taiúva e Bebedouro, este último sede das reuniões do Colegiado. Trata-se de um estudo descritivo analítico nos municípios do Colegiado de Gestão Regional Sul - DRS -5 - Barretos, no período de 2007 e 2010. A descrição da evolução do processo de adesão dos municípios as diretrizes do Pacto pela Saúde foi determinada utilizando o indicador de a abrangência da Estratégia de Saúde da Família, pela proporção da população cadastrada, além dos indicadores de saúde, maternos infantis do Pacto pela Vida.

Resultados: Dentre os dados analisados foram observados pouca evolução nos indicadores de saúde nos anos de 2007 a 2010, os municípios que mais evoluíram foram aqueles que apresentam fortalecimento da atenção básica caracterizado pela melhor cobertura de Estratégia de Saúde da Família, uma provável justificativa para tal comportamento seria as dificuldades dos municípios em formarem uma equipe de profissionais qualificados para realização das etapas do Planejamento em Saúde e monitorá-las, fazendo adequações e correções anuais, de acordo com as mudanças no contexto saúdedoença da população e a estrutura do serviço, a fim de melhorar os indicadores.

Conclusão: A pouca mudança percebida na evolução dos indicadores de saúde maternos - infantis após o Pacto pela Saúde, pode ser atribuída a falta de planejamento e consequentemente a falta de vontade política, ou seja do interesse dos Gestores em abraçar novas perspectivas, e se comprometer diante da proposta. Os municípios com menos de 20.000 habitantes precisam estruturar equipes envolvidas com o diagnóstico de saúde da população de seu território, articulando informações que ajudarão na construção dos indicadores de saúde.Faltam aos Gestores utilizar melhor os instrumentos que os possibilitem planejar de forma clara e com base na realidade dos problemas de saúde de seu município.Outro ponto a ser considerado é a passividade, a apatia política muito presente na Gestão em Saúde.

\section{REPRESENTAÇÕES SOCIAIS DE CUIDADORES DOMICILIARES DE IDOSOS PÓS ACIDENTE VASCULAR ENCEFÁLICO}

\author{
Rosângela deAbreu Venancio Tamanini \\ Orientador: Prof. Dr. Antonio Carlos Duarte de Carvalho \\ Dissertação de Mestrado apresentada em 31/01/2013
}

O aumento da longevidade pode ser considerado como uma das principais conquistas da humanidade no presente século, porém este fenômeno modificou os padrões de morbidade, os cuidados e a atenção prestada à saúde do idoso, 
principalmente devido ao aparecimento das doenças crônicas não transmissíveis (DCNT), como por exemplo, o Acidente Vascular Encefálico (AVE), que ao acarretar sequelas físicas e emocionais pode comprometer a capacidade funcional, autonomia, independência e tornar o idoso acometido dependente de cuidados dos familiares. Sob essa perspectiva este estudo utilizou-se da abordagem qualitativa para identificar e compreender como se dá o processo de assumir a função de cuidador domiciliar do idoso pós AVE, para isso foram realizadas entrevistas semiestruturadas, com seis cuidadores domiciliares assistidos pelo Serviço de Atendimento Domiciliar (SAD) do Município de Ribeirão Preto-SP. A partir da análise dos dados foi possível traçar o perfil sociodemográfico desses participantes, que eram todos do sexo feminino, com grau de parentesco de esposas e filhas, idade variando entre 44 e 71 anos, com predomínio da religião católica, da baixa escolaridade (até cinco anos de estudo) e com renda mensal de aproximadamente R $\$ 1.700,00$. Também foi possível organizar o conteúdo em dois temas: "O processo de cuidar e os sentimentos envolvidos" e "O impacto da doença na família: mudanças na rotina e as estratégias de enfrentamento", os quais apontam e discute a influência de sentimentos como gratidão, obrigação, surpresa frente ao inesperado, raiva, medo, exclusão e sobrecarga, na determinação do cuidador; as alterações sofridas no núcleo familiar após a instauração da doença e quais as formas de enfrentamento utilizadas para superar as questões financeiras, de dinâmica familiar e de problemas de saúde resultantes das exigências de esforço físico e mental advindos do papel de cuidador. Sendo assim, foi possível averiguar a importância do papel de cuidador domiciliar e a necessidade de apoio a esses indivíduos, seja através de programas específicos ou da efetivação dos já existentes a fim de auxiliá-los no desenvolvimento do cuidado adequado ao idoso e na diminuição do aparecimento de problemas em sua saúde.

\title{
ALTERAÇÕES DE FALA EM ESCOLARES
}

\author{
Rosimara Alves Ribeiro \\ Orientador: Prof. Dr. Amaury Lellis Dal Fabbro \\ Dissertação de Mestrado apresentada em 31/01/2013
}

Conhecer a prevalência dos distúrbios da comunicação humana é de fundamental importância, pois possibilita esforços destinados ao fortalecimento de ações de políticas públicas de saúde. Este estudo é do tipo transversal e tem como objetivo estimar a prevalência das alterações de fala e possíveis associações com as alterações da audição e motricidade orofacial em crianças, com idades entre 5 e 8 anos, de ambos os sexos, matriculadas na $1^{\text {a }}$ série de escolas estaduais, municipais e privadas do município de Ribeirão Preto-SP. A amostra foi composta por 232 crianças. Os sujeitos foram submetidos aos seguintes testes de triagem: TERDAF-Adaptado para fala; AMIOFE (aspecto, postura e mobilidade) para motricidade orofacial; teste com audiômetro e imitanciômetro portátil para audição. Os dados foram analisados, utilizando o programa Stata 9.0 e R. O nível de significância estabelecido foi de 5\%. Observou-se prevalência de alterações de fala de 25,9\%, sendo mais frequente no sexo masculino, na faixa etária de 7 a 8 anos e matriculados em escolas municipal e estadual. Verificou-se prevalência de alterações da audição de 35,8\% e 40,1\% da motricidade orofacial. Foram observadas evidências de associação entre as alterações de fala e motricidade orofacial, mas não foram observadas associações entre alterações de fala e audição. A prevalência das alterações de fala mostrou-se alta para a população estudada. Espera-se que este estudo possa contribuir para o planejamento de ações coletivas com vistas à prevenção e à promoção da saúde infantil.

\section{VALOR DA ESPIROMETRIA PARA DETECÇÃO DE ASMA EM ESTUDOS EPIDEMIOLÓGICOS}

\author{
Luciano Penha Pereira \\ Orientador: Prof. Dr. Elcio dos Santos Oliveira Vianna \\ Dissertação de Mestrado apresentada em 28/02/2013
}

O diagnóstico da asma baseia-se na anamnese e no exame clínico, mas provas de função pulmonar e avaliação da alergia contribuem para o diagnóstico. A espirometria é o exame complementar mais utilizado em pacientes asmáticos, por ser útil para o diagnóstico, por ser o exame mais disponível no sistema de saúde, para classificação da gravidade e para o monitoramento terapêutico. A medida da reatividade brônquica é um exame mais demorado, tem maior risco, maior custo e é menos disponível. No entanto, é superior por representar melhor a fisiopatologia da asma. Este projeto tem o objetivo de determinar o valor da espirometria na investigação de asma em estudos epidemiológicos (tendo como referência a medida 
de reatividade brônquica). Foram analisados os dados de 1922 indivíduos que constituíram uma coorte de nascidos em hospitais de Ribeirão Preto em 1978 e 1979. Estes indivíduos preencheram questionários, incluindo o questionário da European Community Respiratory Health Survey; foram submetidos à espirometria e ao teste de broncoprovocação com metacolina, que mede a reatividade brônquica. Para análise dos dados, a asma foi definida pela associação de teste de broncoprovocação positivo com pelo menos um dos sintomas: sibilância, aperto no peito, dispneia, dispnéia noturna. A prevalência de volume expiratório forçado no primeiro segundo menor que oitenta por cento (VEF1 < 80\%) do previsto (espirometria alterada ou VEF1 reduzido) foi de 10,9\%, a prevalência de hiperreatividade brônquica foi de 22,2\% e a prevalência de asma foi de 10,4\% na amostra de 1922 indivíduos. A espirometria teve sensibilidade de 38\% para detectar asma no sexo masculino e de $16 \%$ no sexo feminino com especificidades de $94 \%$ e $90 \%$, respectivamente. Na análise univariada, houve associação entre espirometria alterada e diagnóstico de asma apenas no sexo masculino com razão de prevalência (RP) de 5,31 com intervalo de confiança de $95 \%$ de 3,60-7,83. No sexo feminino, a RP foi de 1,34 (0,87-2,07). Na análise multivariada, a associação entre espirometria alterada e o diagnóstico de asma foi evidenciada em homens pela RP de 4,20 (2,71-6,71), mas não foi evidenciada em mulheres: 1,24 (0,79-1,93). O índice Kappa entre VEF1 reduzido e asma foi de $0,13(0,08$ - 0,19). Portanto, empregando-se o teste de broncoprovocação com sintomas para definir asma, a espirometria demonstra limitações, como baixa sensibilidade, fraca concordância e diferenças na capacidade de detectar asma entre homens e mulheres.

\title{
CARACTERÍSTICAS EPIDEMIOLÓGICAS DAS FRATURAS DO FÊMUR PROXIMAL TRATADAS NA SANTA CASA DE MISERICÓRDIA DE BATATAIS - SP
}

\author{
Anne France Ariyoshi \\ Orientador: Prof. Dr. Amaury Lelis Dal-Fabbro \\ Dissertação de Mestrado apresentada em 01/03/2013
}

As fraturas do fêmur proximal são frequentes em idosos, consideradas uma devastadora consequência da osteoporose, acometem mais o sexo feminino, estão comumente associadas a traumas de pequena energia e, embora apresentem poucas complicações referentes a consolidação no caso das fraturas extracapsulares, estão relacionadas a déficits funcionais, a elevadas taxas de morbidade e mortalidade, além dos altos custos aos serviços de saúde. Representam importante problema de saúde pública mundial devido a sua alta incidência. Trata-se de um estudo retrospectivo com base em um levantamento de prontuários, objetivando caracterizar os pacientes com fraturas do fêmur proximal atendidos na Santa Casa de Misericórdia de Batatais - SP. Foram analisados 258 prontuários, de 258 pacientes, correspondendo a 260 fraturas do fêmur proximal (duas fraturas bilaterais) de indivíduos atendidos na Santa Casa de Misericórdia de Batatais no período/ 01/2007 a dezembro de 2010 com idade média de 74,8 anos, com predomínio de fraturas na faixa etária entre 80 e 89 anos $(35,8 \%)$, mulheres $(64,6 \%)$ e que se declaravam brancos $(73 \%)$. As fraturas trocantéricas foram as mais incidentes com $60 \%$ dos casos, o mecanismo de trauma mais comum foi a queda da própria altura com $91,1 \%$ e o lado mais acometido foi o direito com 51,9\%. O tratamento cirúrgico foi aplicado a 95,7\% das fraturas do fêmur proximal. Dos 258 pacientes incluídos no estudo, 50 foram a óbito, sendo frequente entre as mulheres $(61,6 \%)$ e o período mais incidente foi com três meses após a fratura.

\section{A DINÂMICA DE TRÊS COLEGIADOS DE GESTÃO REGIONAL - UM OLHAR SOBRE A REGIONALIZAÇÃO E PACTUAÇÃO}

\author{
Pedro Silveira Carneiro \\ Orientadora: Prof ${ }^{\mathrm{a}}$. Dr ${ }^{\mathrm{a}}$. Aldaisa Cassanho Forster \\ Dissertação de Mestrado apresentada em 14/03/2013
}

O presente estudo buscou compreender, a partir das percepções dos atores que os constituem, a dinâmica dos Colegiados de Gestão Regional (CGR) do Departamento Regional de Saúde (DRS) XIII no que diz respeito a seus papeis previstos de pactuação e regionalização. Construímos esse entendimento a partir da teoria de Matus do planejamento estratégico e do pensamento estratégico como crítica ao planejamento normativo. O cenário de estudo foi composto pelos Colegiados de Gestão Regional (CGR) pertencentes à região do DRS-XIII, cujo pólo é Ribeirão Preto-SP. A coleta de dados foi realizada nos meses de julho e agosto de 2012 mediante entrevistas realizadas com 21 representantes de três CGR. O 
instrumento de entrevista foi semiestruturado, incluindo uma escala de Likert e uma parte aberta para verificar a opinião sobre sete temáticas pré-definidas existentes na regulamentação relativa aos CGR: "Sobre o Colegiado de Gestão Regional"; "Territorialização"; "Cooperação"; "Regulação"; "Instrumentos de Regionalização"; "Financiamento Solidário" e "Participação Social”. Utilizamos a abordagem qualitativa, usando como método de análise de dados a análise de conteúdo. Os resultados mostraram nas temáticas diversos elementos da dinâmica instituída entre os atores sociais da regionalização presentes no espaço estudado. Entre eles surgiram questões pertinentes às relações entre os entes das diferentes esferas, a presença de lógicas e relações por vezes solidárias e, por vezes, marcadas pelas diferenças de poder, e também as diversas dificuldades da gestão nas temáticas levantadas. Frisamos, no entanto, que percepções de avanços estiveram presentes nas diversas temáticas. Buscou-se, por fim, trazer de forma sistematizada as diferentes visões e perspectivas dos diversos atores em cena, sem a pretensão de esgotar a questão da dinâmica dos CGR, mas trazendo a importância do planejamento em situação de poder compartilhado para a construção da regionalização e do SUS.

\title{
AVALIAÇÃO DOS PADRÕES DE QUALIDADE DA ESTRATÉGIA DE SAÚDE DA FAMÍLIA SEGUNDO O PROJETO AMQ-MS: COMPARAÇÃO ENTRE SERVIÇOS VINCULADOS E NÃO VINCULADOS AO ENSINO
}

\author{
Juliana Marcela Flausino \\ Orientador: Prof. Dr. Altacílio Aparecido Nunes \\ Dissertação de Mestrado apresentada em 18/03/2013
}

Esse é um estudo transversal no campo da saúde coletiva e tem como tema a avaliação de serviços da Atenção Básica à Saúde, vinculados ou não ao ensino, em dois municípios do interior paulista. O objetivo geral foi avaliar e comparar o desempenho do processo de trabalho em equipe, segundo padrões de qualidade da Estratégia de Saúde da Família, baseando-se na Proposta AMQ-MS, em Unidades de Saúde da Família nos municípios de Ribeirão Preto e São José do Rio Pardo, e como específicos: descrever as características gerais das Unidades de Saúde da Família incluídas no estudo em Ribeirão Preto e São José do Rio Pardo; verificar os estágios de desenvolvimento alcançados pelos municípios considerando o componente de trabalho das equipes; descrever e analisar pontos fortes e fracos ao desenvolvimento da qualidade e avaliar comparativamente os resultados obtidos entre as equipes das unidades de Ribeirão Preto, onde há atividades de ensino de e São José do Rio Pardo, onde tais atividades não existem. No período de abril a junho de 2011, foram aplicados os instrumentos 04 e 05 do AMQ, ambos relacionados à Unidade de Análise: a Equipe. Foi realizada análise de concordância para fins comparativos, enquanto que para verificar associação, foi empregada a razão de prevalência (RP) e seu intervalo de confiança a 95\% (IC 95\%) como estimadora de magnitude entre variáveis. Para comparação de proporções foi empregado o teste de Z. Em todas as análises considerou-se um nível de significância de 5\%. A concordância entre os resultados foi feita por meio da estatística Kappa. A pesquisa revelou que as USF pesquisadas em Ribeirão Preto não foram privilegiadas em qualidade quando comparadas as USF pesquisadas em São José do Rio Pardo, onde referente à Consolidação ao Modelo o município de Ribeirão Preto encontrou-se no estágio considerado satisfatório e São José do Rio Pardo no estágio considerado regular. Em relação à Atenção a Saúde e no Componente: Equipes, envolvendo os dois instrumentos, os dois municípios se enquadram no estágio satisfatório. O pior desempenho por subdimensão foi apresentado na "Participação Comunitária e Controle Social" considerado fraco. Observou-se não linearidade entre a complexidade de implementação dos processos de trabalho e a autoavaliacão das equipes de saúde da família dos municípios estudados.

\section{ANÁLISE DE CUSTO-EFETIVIDADE DO TRATAMENTO SUPERVISIONADO E AUTOADMINISTRADO DA TUBERCULOSE}

\author{
Michela Prestes Gomes \\ Orientador: Prof. Dr. Antonio Ruffino Netto \\ Dissertação de Mestrado apresentada em 27/03/2013
}

A tuberculose (TB) é uma das importantes causas de mortalidade no mundo, e apresenta alta prevalência e incidência no Brasil, o qual se encontra entre os países com maiores números de casos da doença. O objetivo desse trabalho foi efetuar um estudo sobre custo-efetividade do tratamento para tuberculose (abordando as estratégias de tratamento 
supervisionado e autoadministrado), buscando evidencias para estimar custos diretos (no distrito oeste de Ribeirão Preto-SP) e custos indiretos (para algumas regiões deste município). Por ser uma doença associada às condições sociais e econômicas (nelas incluídas o Brasil), buscou-se observar as deficiências das organizações e gestão do sistema de saúde, através da análise dos custos gerados pela TB. Foi efetuado um estudo epidemiológico, descritivo, pesquisa avaliativa, visando coletar dados sócio-demográficos, e características sobre acompanhamento e evolução do tratamento através dos prontuários dos doentes de TB para estimativa de custos diretos, e também estimar os custos indiretos através de entrevista com os pacientes. A fim de efetuarmos a análise de custo-efetividade do tratamento diretamente observado (TDO) e autoadministrado (TAA) da TB. Foram amplamente discutidos a qualidade dos dados, e realizadas as estimativas dos custos: direto, resultando em $\mathrm{R} \$ 1075,39$ (para estratégia TDO) e R $\$ 806,98$ (estratégia TAA); e indireto, resultando em R \$2001,39 (para TDO) e R \$974,53 (para TAA). Encontrou-se uma Razão de Custo-efetividade Incremental (RCEI) negativo de 8.0562 por tratamento concluído da estratégia TDO em relação ao TAA. 